\title{
ESTIMATIVA DAS PERDAS DE RENDIMENTO DOS TRABALHADORES DEVIDO A CONDIÇÕES INADEQUADAS DE NUTRIÇÃO
}

\section{ELKER TEODORO PINTO DE CASTRO}

Economista

Orientadora: Prof ${ }^{a}$. Dr ${ }^{\mathrm{a}}$. ANA LÚCIA KASSOUF

Dissertação apresentada à Escola Superior de Agricultura "Luiz de Queiroz", Universidade de São Paulo, para obtenção do título de Mestre em Ciências, Área de Concentração: Economia Aplicada.

\section{PIRACICABA}

Estado de São Paulo - Brasil

Outubro - 1997 
Dados Internacionais de Catalogação na Publicação (CIP) DIVISĀo DE BIBLIOTECA E DOCUMENTAÇĀO - Campus "Luiz de Queiroz"/USP

Castro, Elker Teodoro Pinto de Estimativa das perdas de rendimento dos trabalhadores devido a condiçōes inadequadas de nutriçāo / Elker Teodoro Pinto de Castro. - - Piracicaba, 1997.

117 p. : il.

Dissertaçāo (mestrado) - - Escola Superior de Agricultura Luiz de Queiroz, 1998. Bibliografia.

1. Desnutriçāo humana 2. Estimativa 3. Saneamento básico 4. Trabalhador (rendimento) l. Título 


\title{
ESTIMATIVA DAS PERDAS DE RENDIMENTO DOS TRABALHADORES DEVIDO A CONDIÇÕES INADEQUADAS DE NUTRIÇÃO
}

\author{
ELKER TEODORO PINTO DE CASTRO
}

Aprovada em: $\quad 05.12 .97$

Comissão Julgadora:

Prof. Dr. Rodolfo Hoffmann

ESALQ/USP

Prof. Dr. Antonio Carlos Campino

FEA/USP

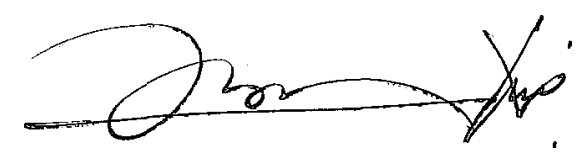

Prof. Joaquim Bento de Souza Ferreira Filho Substituindo a orientadora 


\section{AGRADECIMENTOS}

A Prof ${ }^{a}$ Ana Lúcia Kassouf, pela valiosa orientação, apoio e incentivos que permitiram a realização deste trabalho;

Ao Prof. Joaquim Bento de Souza Ferreira Filho pelo apoio e amizade.

Aos Profs. Paulo Fernando Cidade de Araújo e Roldofo Hoffmann pelas críticas e sugestões apresentadas.

Ao Prof. Antonio Carlos Campino pela participação na comissão julgadora.

Aos Professores e Funcionários do Departamento de Economia e Sociologia Rural da ESALQ/USP, pelos ensinamentos, em especial a bibliotecária Luciane pela amizade e carinho, quando da utilização de seus serviços.

Aos colegas de Pós-Graduação, pela amizade e agradável convivência durante o curso.

À Capes, pela bolsa de mestrado;

Aos meus pais José Mauro e Celina, aos tios Laércio, Celia, Dagoberto e Gracie pelo apoio incondicional em todos os momentos do curso.

A todos que contribuíram para a realização deste estudo. 


\section{Para}

José Pinto de Castro

(in memorian) 


\section{SUMÁRIO}

Página

LISTA DE FIGURAS ................................................................................... iii

LISTA DE TABELAS ............................................................................. iv

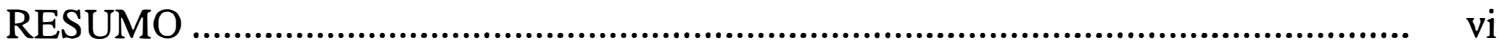

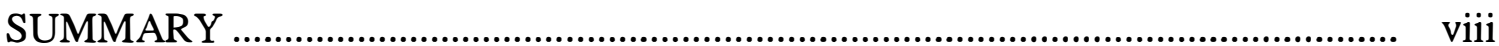

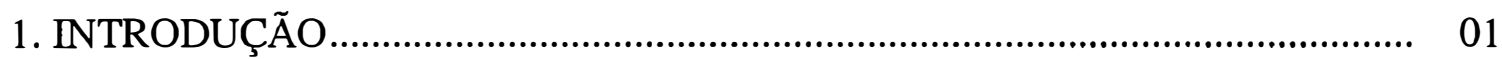

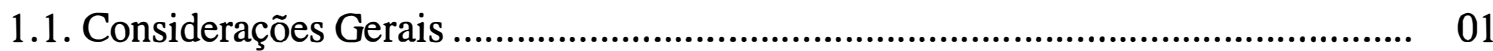

1.2. O problema e sua importância.................................................................... 08

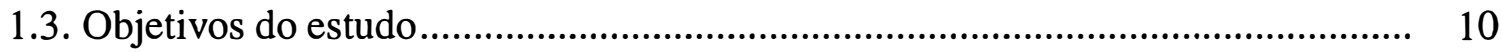

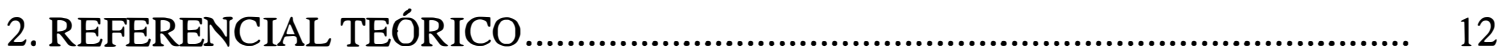

2.1. A origem e a definição do conceito de capital humano ...................................... 12

2.2. Um breve histórico do desenvolvimento dos indicadores sociais de produtividade do trabalho relacionados ao estado de saúde

2.2.1. Das condições nutricionais até as primeiras inferências sobre produtividade do trabalho

2.2.2. A construção de novos indicadores sociais de produtividade do trabalho

2.3. Algumas evidências empíricas sobre as condições ambientais e seu relacionamento com o estado de saúde

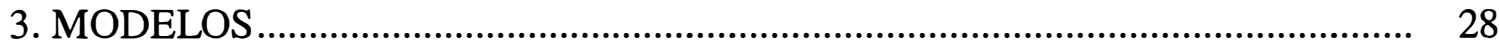

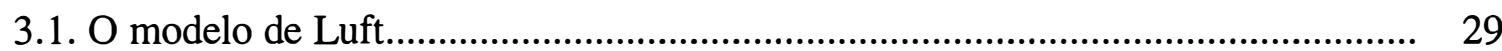

3.2. O modelo de Haveman derivado do modelo de Rice ........................................ 31

3.2.1. O conceito de perda de capacidade de rendimento........................................ 32

3.2.2. O conceito de perda de rendimento ............................................................ 33

3.3. As similaridades e diferenças entre os modelos de perdas de rendimento 
3.4. O modelo de Becker ..................................................................................... 36

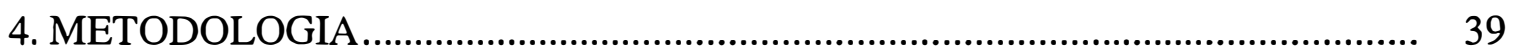

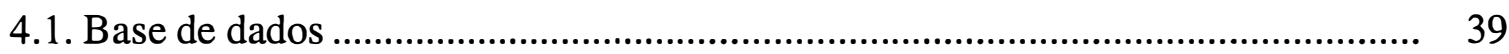

4.2. A utilização de medidas antropométricas para se captar o estado de saúde

4.3. A composição da amostra da PNSN: Uma análise da dimensão do problema nutricional de adultos no Brasil .................................................. $\quad 42$

4.4. Modelos econométricos...................................................................................... 48

4.4.1. O modelo econométrico adotado no estudo: procedimentos e descrição das variáveis ................................................................................ 49

4.4.2. A equação de saúde: descrição das variáveis ................................................... 52

4.5. A seleção da amostra ................................................................................ 56

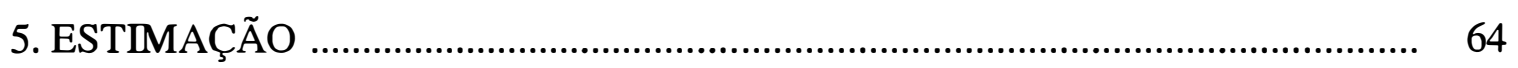

5.1. O procedimento de Heckman na obtenção da estimativa do

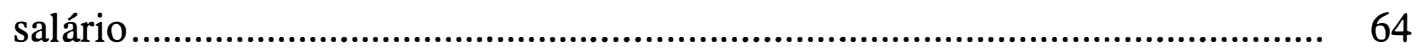

5.2. O modelo econométrico de Heckman ............................................................ 65

5.3. A aplicação domedelo de Heckman na obtenção das perdas de

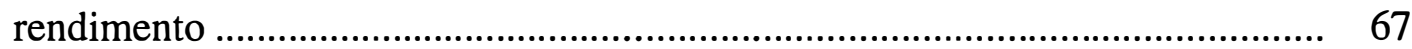

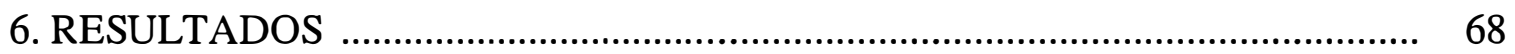

6.1. As estimativas das perdas de rendimento ................................................... 68

6.2. As equações de saúde ................................................................................... 80

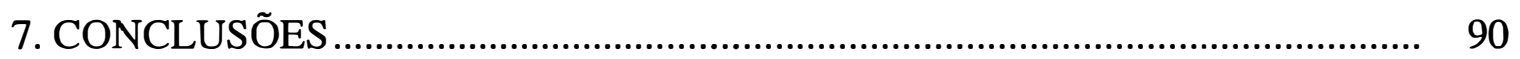

8. REFERÊNCIAS BIBLIOGRÁFICAS......................................................... 92

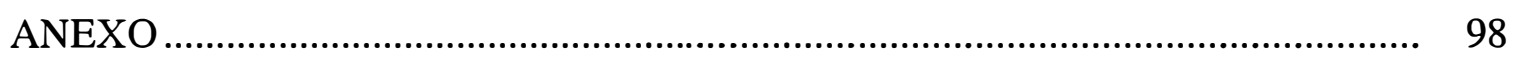




\section{LISTA DE FIGURAS}

Página

1 Porcentagem do Produto Nacional Bruto Gasto em Saúde nos Estados Unidos, 1929-2000

2 Prevalência (\%) de baixo peso, sobrepeso e obesidade, segundo sexo. Brasil, 1989.

3 Prevalência (\%) de sobrepeso e obesidade segundo sexo e idade, Brasil, 1989

4 Prevalência (\%) de baixo peso segundo sexo e idade. Brasil, 1989. 45

5 Prevalência (\%) de baixo peso, obsedidade, padrão normal, sobrepeso e obesidade, segundo regiões, Brasil, 1989.

6 Distribuição percentual das perdas de rendimento por hora de trabalho do tipo 1 e tipo 2 entre regiões e setores do Brasil, 1989.

7 Distribuição percentual das perdas totais de rendimento por hora de trabalho entre regiões e setores do Brasil, 1989.

8 Taxa de crescimento de hospitais e ambulatórios nas regiões e Brasil entre 1980 e 1989 


\section{LISTA DE TABELAS}

Página

1 Frequência e Posição no Ranking de Algumas Causas Evitáveis de Hospitalização na Rede do Sistema Único de Saúde (SUS) - 19841991.

2 Evolução Percentual dos Gastos com Saúde em Relação ao PIB do Brasil, 1980-1990.

3 Prevalência (\%) de obesidade segundo sexo, situação de domicílio e renda domiciliar mensal per capita no Brasil, 1989.

4 Descrição das variáveis explicativas e dependentes no modelo 50

5 Descrição dos dados e cálculos a serem adotados na estimativa das perdas de rendimento total

6 Descrição das variáveis utilizadas no modelo de Becker adaptado

7 População de homens saudáveis, população de homens doentes e variação percentual por regiões e setores do Brasil (exclusive a população rural da Região Norte), de 1989.

8 População de mulheres saudáveis, população de mulheres doentes e variação percentual por Região e Setores do Brasil (exclusive a população rural da Região Norte), de 1989.

9 Médias da equação de participação para homens saudáveis e doentes, por regiões e setores, de 1989.

10 Médias da equação de participação para mulheres saudáveis e doentes, por regiões e setores, de 1989.

11 Equação ajustada de participação no mercado de trabalho para homens saudáveis e doentes, de acordo com as regiões e setores, 1989.

12 Equação ajustada de rendimento para homens saudáveis e doentes, de acordo com as regiões e setores, 1989 
13 Perdas de rendimento por hora em dólares para os homens adultos do Brasil, 1989.

14 Perda total de rendimento por hora e perda potencial de rendimento por ano em milhões de dólares para a população masculina do Brasil, 1989.

15 Perdas de rendimento por hora em dólares para mulheres adultas no Brasil, 1989.

16 Equações de saúde para homens e mulheres normais e de baixo peso $(\mathrm{IMC}<25)$ de 18 a 65 anos

17 Equações de saúde para homens e mulheres normais com sobrepeso e obesidade (IMC $\geq 20$ ) de 18 a 65 anos

18 Oferta de leitos por 1.000 habitantes e 1.000 habitantes por ambulatório no Brasil, 1989.

19 Necessidades de investimento em saneamento urbano no Brasil em milhões de dólares, 1990 


\title{
ESTIMATIVA DAS PERDAS DE RENDIMENTO DOS TRABALHADORES DEVIDO A CONDIÇÕES INADEQUADAS DE NUTRIÇÃO
}

\author{
Autor: ELKER TEODORO PINTO DE CASTRO \\ Orientadora: PROF $^{\mathrm{a}}$. ANA LÚCIA KASSOUF
}

\section{RESUMO}

Este estudo tem como objetivo principal estimar as perdas de rendimento dos homens e mulheres adultos (18 a 65 anos) devido à ausência de condições adequadas de nutrição, assim como relacionar os efeitos das condições adversas de saneamento básico na saúde dos indivíduos.

São utilizados dados individuais fornecidos pelas Pesquisa Nacional sobre Saúde e Nutrição (PNSN), a partir das quais foram selecionadas as variáveis utilizadas na estimação das equações de participação no mercado de trabalho, rendimento e saúde.

A estimativa das perdas de rendimento é obtida através do ajustamento de equações de participação no mercado de trabalho e rendimento. O procedimento de Heckman foi utilizado para se eliminar o problema de seletividade amostral e obter estimativas consistentes dos parâmetros, corrigindo os problemas gerados pela não inclusão das pessoas adultas que não recebiam salário. Primeiramente foi estimada a equação de participação no mercado de trabalho através do modelo Próbite. De acordo com os coeficientes da variável dependente Trabalha na equação de participação foi estimada a variável LAMBDA(inverso da razão de Mill), que foi utilizada como variável explicativa na equação de rendimentos. As equações de rendimento e participação foram estimadas de acordo com o sexo, estado de saúde, região e setor.

Para a estimativa das perdas de rendimento foi utilizado o modelo de Luft (1974). Adotando-se o conceito de capacidade potencial de horas de trabalho, proposto por Haveman (1995), foram calculadas as perdas totais de rendimento potencial. 
As perdas de rendimento dos indivíduos que estão atuando no mercado de trabalho foram superiores às perdas dos homens que estão fora do mercado de trabalho quando se considera a amostra masculina. Além disso, as estimativas demonstraram que as regiões Sudeste e a Nordeste e o setor Urbano foram os que apresentaram as maiores perdas de rendimento. As estimativas das perdas de rendimento para as mulheres não permitiram inferências sobre as perdas de rendimento totais devido aos sinais negativos encontrados para a maioria das regiões e o setor Urbano.

Para a estimativa das equações de saúde foi utilizado o modelo de Becker $(1965,1981)$, que introduz a alocação de tempo e atividades produtivas do domicílio na teoria do consumidor.

A infra-estrutura do domicilio, objetivo principal das equações de saúde, as variáveis Abastecimentoágua, Esgoto, Lixo e Luz, com raras exceções, mostraram um efeito positivo na saúde, confirmando a idéia de que o saneamento básico possui grande importância para melhores condições de saúde.

Os resultados permitem concluir que as perdas de rendimento para os trabalhadores devido às condições inadequadas de nutrição são elevadas, sendo a inexistência dos serviços de saneamento básico um importante fator explicativo para as referidas perdas. 


\title{
ESTIMATE OF LABOR EARNINGS LOSSES DUE TO ADVERSE HEALTH
}

\author{
Author: ELKER TEODORO PINTO DE CASTRO \\ Adviser: ANA LÚCIA KASSOUF
}

SUMMARY

The major objective of this study is to estimate the adult men and women earnings losses (18 to 65 years of age) due to the lack of adequate nutrition conditions as well as to determine the effect of the adverse basic sanitation conditions on the individual health.

Data from the national survey on health and nutrition (PNSN) were used to select the variables used for estimating the labor market participation, earnings and health equations.

Productivity losses estimates are obtained through the estimation of labor market participation and earnings equations. Heckman's procedure was used in order to eliminate the sample selectivity problem and to obtain consistent parameter estimates, correcting the problems generated by not including adult individuals that were not receiving wage. First, the labor market participation equation was estimated using a probit model. The Lambda variable (inverse of the mill ratio) was estimated from the coefficient of the dependent "works" variable in the participation equation. Lambda was used as an explanatory variable in the productivity equation. Participation and earnings equations were estimated for sex, health condition, region and sector.

Luft's model was used to estimate earnings losses. Total losses of potential earnings were calculated using Haveman's concept of working hours potential capacity. 
Earnings losses of individuals in the labor market were higher than the ones of those out of it for the male sample. In addition, estimates show that southeast and north-east regions and the urban sector present the highest earnings losses. Earnings losses estimates for women presented negative signs for most regions and the urban sector.

Becker's model was used to estimate health equations. The model introduces the allocation of time and household productive activities in consumer theory.

Home infrastructure, main objective of health equations, the variables water supply, sewerage, garbage and electricity, with few exceptions, cause a positive effect on health. Those results confirm the idea that basic sanitation's very important for the improvement of health conditions.

The results permit to conclude that labor earnings losses due to adverse health conditions are high. Lack of basic sanitation services is one important factor in explaining those losses. 


\section{INTRODUÇÃO}

\subsection{Considerações gerais}

O Brasil apresentou, nas últimas décadas, significativas mudanças nas condições de vida e saúde da população. Ao se analisar alguns indicadores dos níveis globais de saúde da população brasileira, constata-se significativo aumento da expectativa de vida, reduções nos indicadores de mortalidade infantil e mortalidade ocasionadas por doenças infecciosas.

Segundo Barros et al (1996), um dos fatores que exemplificam as profundas transformações no padrão de vida e condições de saúde da população brasileira é o processo de envelhecimento que o país vem experimentando nos últimos anos. Este processo tem ocorrido devido à constante queda da taxa de natalidade, em maior magnitude, do que a redução da taxa de mortalidade. A diminuição da taxa de crescimento populacional é conseqüência imediata da transformação demográfica que acontece no Brasil.

Helena Alvim (1989), destaca que a mudança no padrão demográfico brasileiro possibilita ampla margem de discussão. Entretanto, ela ressalta que no que se refere aos diferentes tipos de família, o número de casal com filhos é mais frequente no meio rural que no meio urbano, sendo que enquanto no meio rural, $65,9 \%$ das famílias são integradas com filhos, no meio urbano não passam de 57,4\%. Este comportamento seria explicado pela menor duração média de casamentos no setor urbano que no rural; 
um planejamento familiar mais rigoroso nas áreas urbanas levando a um maior número de casais sem filhos. Outro aspecto a ser levado em consideração seria a importância da família completa em função da produção organizada de forma familiar. Estes fatores justificariam a maior incidência de famílias constituídas por casal com filhos no campo que na cidade. $\mathrm{O}$ processo de urbanização que aconteceu nas últimas décadas seria o principal fator explicativo para a mudança no padrão demográfico brasileiro. Para Smith \& Oliveira (1995), a disseminação do uso da pílula anticoncepcional e de outros métodos anticonceptivos foram mais recentemente sobrepostos pelo avanço da prática da esterilização feminina que, por ser irreversível, vem afetando a estrutura demográfica brasileira de forma permanente.

Segundo o Relatório Sobre o Desenvolvimento Mundial (1993), a expectativa de vida ao nascer no Brasil tem aumentado, passando de 45,9 anos na década de 50 para 66 anos no início da década de 90.

Um aspecto preocupante, presente nas informações existentes sobre o nível de natalidade e mortalidade da população brasileira, refere-se à seletividade espacial e social destes indicadores. Medice \& Beltrão (1996) destacam que, embora a mortalidade venha se reduzindo progressivamente no país, os grupos de mais baixa renda continuam a deter taxas elevadas de fecundidade e, em muitos casos de mortalidade, acontecendo o inverso com os segmentos de rendas mais altas.

Outro aspecto a ser levado em consideração ao se analisar as condições atuais de saúde da população brasileira é o fato de o Brasil apresentar padrões epidemiológicos que refletem modificações na composição de mortalidade por grupo de causas. De acordo com Barros et al. (1996), a característica mais marcante diz respeito à constante queda da mortalidade causada pelas doenças infecciosas e parasitárias e a ascensão de doenças cardiovasculares. A partir da década de 60 as doenças cardiovasculares passam a ser responsáveis pela maior proporção de óbitos registrados no país. É certo que, 
durante a década de 50, os serviços de saúde passaram por profundas transformações que possibilitaram a modificação dos padrões epidemiológicos existentes na época. A implementação de programas de medicina preventiva, medidas de vacinação em massa e de alguns cuidados primários de saúde são fatores explicativos para tal transformação.

Ainda, segundo Barros et al (1996), apesar da melhora em alguns indicadores de níveis de saúde ao longo das últimas décadas, nota-se o crescimento das doenças de origem ambiental, isto é aquelas causadas por falta de saneamento básico e moradia adequada. Como exemplo, pode-se citar a cólera, dengue, esquistossomose e febre tifóide, entre outras doenças.

A inexistência de serviços básicos de coleta de lixo, abastecimento de água e tratamento de esgotos provocam sérios problemas à saúde da população. De acordo com o Relatório Sobre o Desenvolvimento Mundial (1993), dois milhões de mortes por ano poderiam ser evitadas no mundo, se houvesse saneamento básico e água tratada.

No Brasil, as condições de saneamento básico são preocupantes. De acordo com o Relatório sobre o Desenvolvimento Humano no Brasil (1996), no que se refere ao esgoto sanitário, apenas $28,5 \%$ da população, tem o esgoto urbano tratado e fossa séptica. A média brasileira na rede pública de coleta de lixo no setor urbano é de 78,4\%. $\mathrm{Na}$ área de abastecimento de água a situação é melhor, tendo em vista que $87 \%$ dos domicílios urbanos são atendidos.

Ao observar a Tabela 1, constata-se que, durante os anos de 1985 a 1991, as internações provocadas por causas evitáveis cresceram significativamente. As infecções intestinais cresceram 59\% e as internações por deficiência nutricional cresceram 78\%. 
Tabela 1 - Frequência e Posição no Ranking de Algumas Causas Evitáveis de Hospitalização na Rede do Sistema Único de Saúde (SUS) - 1984-1991.

\begin{tabular}{lccccccc}
\hline \multicolumn{7}{c}{ Causas de Internação } \\
\hline Ano & \multicolumn{2}{c}{ Infecções } & \multicolumn{2}{c}{ Deficiência } & Total \\
& \multicolumn{2}{c}{ Intestinais } & \multicolumn{2}{c}{ Nutricional } \\
\hline & Número & $\%$ & Número & $\%$ & Número & $\%$ \\
1985 & 558.237 & 4,62 & 82.465 & 0,68 & 12.095 .740 & 100 \\
1986 & 592.062 & 5,20 & 79.152 & 0,69 & 11.391 .826 & 100 \\
1987 & 685.907 & 5,83 & 94.663 & 0,81 & 11.758 .245 & 100 \\
1988 & 764.852 & 5,79 & 109.612 & 0,83 & 12.193 .637 & 100 \\
1989 & 749.197 & 6,14 & 118.224 & 0,97 & 11.796 .360 & 100 \\
1990 & 766.834 & 6,50 & 124.415 & 1,05 & 11.796 .360 & 100 \\
1991 & 890.900 & 6,57 & 142.219 & 1,05 & 13.568 .485 & 100 \\
\hline
\end{tabular}

Fonte: Barros et al (1996)

Como a população de baixa renda depende quase que exclusivamente da rede pública de saúde, é fácil prever o aumento da pressão sobre os gastos públicos em saúde devido à inexistência de serviços de saneamento básico e infra-estrutura.

Outro ponto muito relevante ao se analisar a problemática da saúde no Brasil é a existência de enormes desigualdades sócio-econômicas entre as diferentes regiões. Os indicadores de saúde, também, refletem as desigualdades regionais. O coeficiente de mortalidade infantil pode ser utilizado para exemplificar esta situação. Segundo Barros et al. (1996), na última década, o coeficiente de mortalidade infantil, que indica o número de mortes por mil nascimentos, apresentava taxas de 43 na região Sul, 33 na região Sudeste e 74 na região Nordeste. Conclui-se que a região Nordeste apresentava taxas $72 \%$ superiores às da região Sul e $124 \%$ superiores às da região Sudeste. O aumento dos gastos públicos no setor de saúde, seja em saneamento básico ou em serviços médicos, aumenta no mundo inteiro. De acordo com Folland et al. (1993), um 
em cada oito dólares gastos em bens finais na economia norte-americana são alocados no setor de saúde.

A projeção apresentada no Figura 1 mostra que no ano de 1929 apenas 3,5\% do Produto Nacional Bruto (PNB) americano eram gastos em saúde, incluindo as despesas públicas e privadas. Já no início da década de 90 os gastos em saúde correspondiam a $12,2 \%$ do PNB e a projeção feita para o ano 2000 aponta para $16,4 \%$ do PNB.

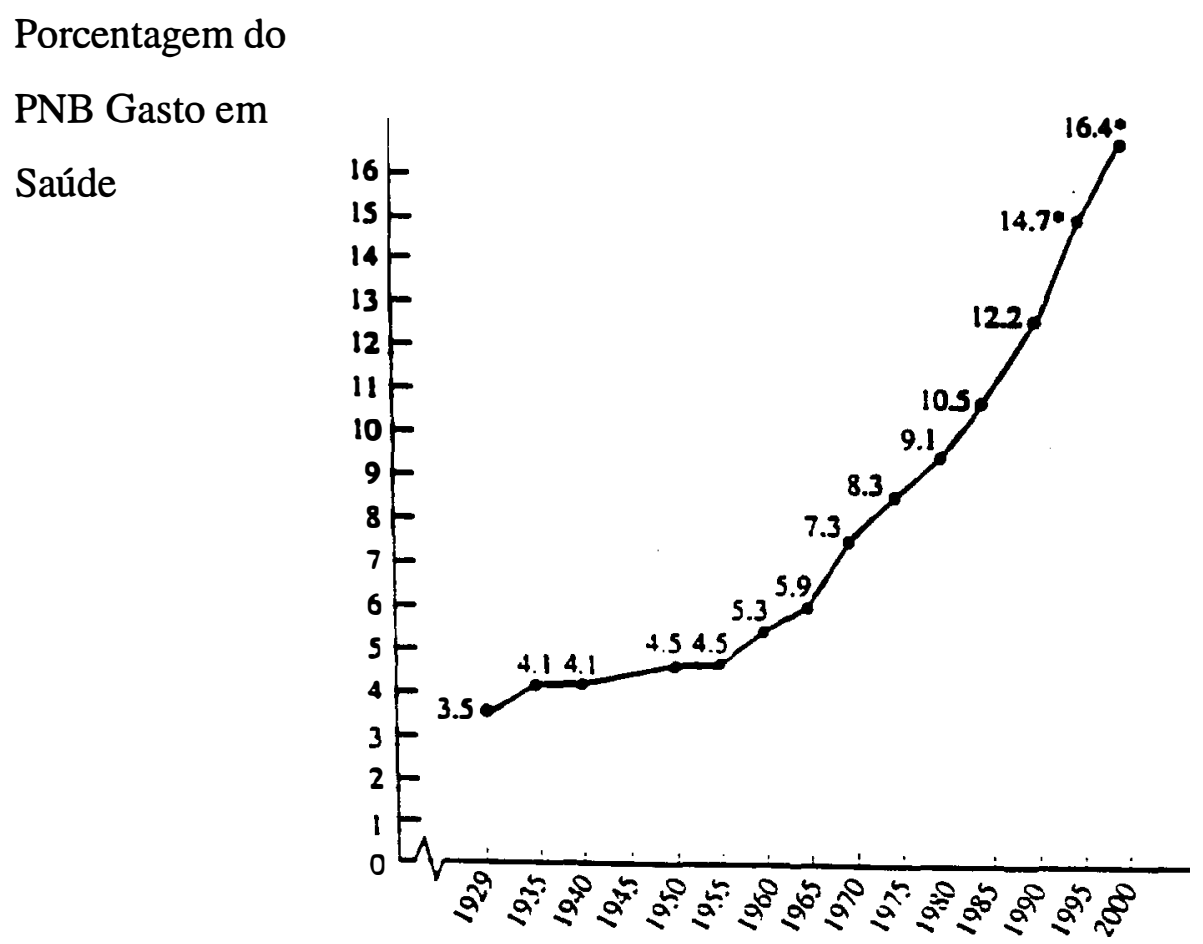

ano

Fonte: Folland et al. (1993).

Figura 1 - Porcentagem do Produto Nacional Bruto Gasto em Saúde nos Estados Unidos, 1929-2000

No Brasil as despesas públicas com saúde, como parcela do PIB, alcançaram a sua maior participação no ano de 1989 com uma taxa de 3,5\%, e a menor no ano de 1983, quando a taxa de participação ficou em 2,14\%, como pode ser visto na Tabela 2. 
Ao se analisar, de maneira específica, os gastos da União na década de 80, observa-se que até o ano de 1986 ocorreram flutuações de menor magnitude. Já a partir de 1987, os gastos federais em saúde aumentaram consideravelmente, mantendo tendência de estabilização até o fim da década. Porém, as informações presentes na Tabela 2 são inequívocas no que se refere a manutenção dos gastos estaduais em níveis constantes. Os municípios dobraram os gastos com saúde, apesar de continuarem com menor participação comparativamente aos Estados e a União.

Tabela 2 - Evolução Percentual dos Gastos com Saúde em Relação ao PIB do Brasil, 1980-1990

\begin{tabular}{lllll}
\hline Anos & Total & União & Estados & Municípios \\
\hline 1980 & 2,34 & 1,75 & 0,42 & 0,17 \\
1981 & 2,36 & 1,74 & 0,44 & 0,18 \\
1982 & 2,37 & 1,75 & 0,41 & 0,20 \\
1983 & 2,14 & 1,55 & 0,41 & 0,18 \\
1984 & 2,15 & 1,60 & 0,39 & 0,16 \\
1985 & 2,23 & 1,60 & 0,42 & 0,21 \\
1986 & 2,27 & 1,56 & 0,47 & 0,24 \\
1987 & 2,81 & 2,33 & 0,25 & 0,23 \\
1988 & 2,69 & 2,31 & 0,00 & 0,38 \\
1989 & 3,26 & 2,52 & 0,38 & 0,36 \\
1990 & 3,19 & 2,32 & 0,49 & 0,38 \\
\hline
\end{tabular}

Fonte: Barros et al. (1996)

Pode-se concluir que a União manteve sempre uma grande participação, mesmo após a Constituição de 1988, que aumentou significativamente o repasse de verbas federais para os Estados e Municípios. 
De acordo com Barros et al (1996), não obstante as frequentes alusões ao sucateamento do setor público em decorrência da redução dos aportes governamentais depois do boom dos anos 70, na verdade, durante a chamada década perdida ${ }^{1}$ os dispêndios per capita com saúde cresceram 9,55\%.

A tendência de envelhecimento, a modificação do padrão epidemiológico da população brasileira, assim como as desigualdades regionais demandarão a elevação dos gastos públicos no setor de saúde, tornando os trabalhos econômicos no setor de saúde de suma importância para a melhor alocação de recursos, bem como para a compreensão da dinâmica das condições de saúde e bem-estar. Algumas instituições confirmam a importância deste tipo de estudo.

“A atenção dos técnicos e pesquisadores na área tem historicamente se concentrado no grupo materno-infantil, dada a maior vulnerabilidade biológica que lhe atribuem e a importância que assumia, frente ao quadro epidemiológico do país. Entretanto, o Brasil vem apresentando uma transição importante no seu perfil epidemiológico. O acompanhamento da situação nutricional de toda a população brasileira, bem como a geração de informações que auxiliem no entendimento da questão, são fundamentais para o planejamento e monitoramento destas ações e devem ser enfocados como atividades prioritárias" (INAN, 1991, p.35).

É neste contexto que este estudo se enquadra, tendo em vista que procurará responder questões fundamentais para o entendimento desta nova realidade, permitindo a geração de um valioso conjunto de informações para o planejamento das ações governamentais na área de saúde.

\footnotetext{
1 A década de 80 é conhecida como década perdida devido à estagnação da taxa de crescimento do PIB per capita, que manteve-se praticamente nula.
} 


\subsection{O problema e sua importância}

A primeira questão a ser respondida neste estudo será verificar quantos milhões de dólares o trabalhador adulto brasileiro perdeu de rendimento devido a problemas de saúde ou, em outras palavras, a idéia é o de quantificar em termos monetários as perdas de rendimento oriundas de condições inadequadas de nutrição para as diferentes regiões e setores do país no ano de 1989.

Em termos econômicos, a melhoria das condições de saúde ${ }^{2}$ e meio ambiente 3 propiciam diversos benefícios. É certo que melhores condições de saúde permitem ao trabalhador realizar suas atividades produtivas de maneira adequada, evitando, do ponto de vista econômico, elevadas perdas para a sociedade. Os ganhos de produtividade advindos de melhores condições de saúde ocorrem por causa da diminuição dos dias perdidos devido a doenças e à maior disposição ao trabalho por parte dos indivíduos. Isto também provoca redução da pobreza, tendo em vista que a melhoria na saúde induz o aumento da produtividade e melhores oportunidades de emprego.

Neste sentido, ressalta-se a importância de estudar os efeitos de condições inadequadas de nutrição na produtividade da força de trabalho através das perdas de rendimento nos setores e regiões brasileiras.

Outro aspecto relevante ao se destacar a importância deste objetivo é o fato de que o rendimento desempenha um papel fundamental na determinação dos gastos com serviços médicos e alimentação na maioria das famílias brasileiras. Hoffmann (1993) analisa a relação entre recebimento familiar e despesas com alimentação na região

\footnotetext{
${ }^{2}$ Saúde, neste estudo, será mensurada pelo Índice de Massa Corporal (IMC) para os adultos. Esse índice é obtido pela divisão do peso pelo quadrado da altura. Apesar de ser um conceito restrito, acredita-se que o mesmo seja o mais adequado para o tipo de abordagem adotada.

${ }^{3} \mathrm{O}$ termo meio ambiente é entendido neste estudo como o saneamento básico (abastecimento de água, esgoto sanitário, limpeza pública e coleta de lixo); além das condições de salubridade da residência, que incluem, por exemplo, o asfaltamento das ruas.
} 
metropolitana de São Paulo e verifica que a participação das despesas com alimentação no total das despesas correntes tende a diminuir com o aumento da renda, passando de $40,6 \%$ na classe mais pobre para $13,8 \%$ na classe mais rica. Além disso, pode-se salientar que uma grande parcela da população brasileira tem o seu rendimento associado ao salário mínimo. Portanto, se um chefe de família, pertencente a um extrato de renda inferior, é acometido por uma doença os efeitos para o rendimento familiar são consideráveis. Nesta situação maior porcentagem do rendimento será gasto em alimentação.

Diversos estudos procuraram estimar as perdas de rendimento devido a condições de inadequadas de nutrição, destacando-se os elaborados por Luft (1974) e Cooper \& Rice (1976). Uma das principais conclusões apresentadas por Luft (1974) foi a de que nos Estados Unidos a perda global de salário devido a doenças para adultos com idade entre 18 e 64 anos era de 22,8 bilhões de dólares no ano de 1966. Mais da metade da perda total foi devido à não participação no mercado de trabalho de 2,9 milhões de pessoas que perderam, em média, 4100 dólares ao ano. Seguindo esta linha de investigação Cooper \& Rice (1976) encontraram perdas de 83,4 bilhões de dólares, ou seja, 3,5\% do PNB norte-americano por ano.

O segundo aspecto a ser investigado por este estudo refere-se à relação entre a disponibilidade da infra-estrutura no domicílio (esgoto sanitário, coleta de lixo, abastecimento de água e energia elétrica) e as condições de saúde do trabalhador. A idéia é obter equações de saúde que permitam captar a importância dos serviços de saneamento básico para a saúde do trabalhador. Vale salientar que esse objetivo permite explicar um dos fatores mantenedores das perdas de rendimento devido a condições adversas de nutrição. De acordo com o Relatório sobre o Desenvolvimento Humano no Brasil (1996), a inexistência de serviços de saneamento básico pode ser apontada como uma das principais fontes causadoras de doenças no Brasil e, portanto, de perda de capacidade salarial devido a doenças. 
O estudo das perdas de rendimento e do impacto da infra-estrutura na saúde dos indivíduos possibilitará maior clareza na dinâmica da condição de saúde brasileira entre diferentes regiões. Além disso, de acordo com o Relatório Sobre o Desenvolvimento Mundial (1990), são os pobres do Brasil que possuem as maiores taxas de mortalidade por doenças relacionadas às condições de saneamento básico. Sendo assim, as estratégias de prevenção devem ser baseadas nesta realidade.

Diversos estudos procuraram relacionar a saúde com a produtividade do trabalho, tentando captar os efeitos da produtividade e o consumo de calorias nos salários (Leibenstein (1957) e Bliss \& Stern (1978), entre outros). Entretanto, estes estudos não se preocupavam em estimar as perdas econômicas atribuídas às limitações de saúde dos indivíduos. Um dos primeiros estudos com esta intenção foi o de Luft (1974), que também teve o mérito de criar uma metodologia para quantificar estas perdas. Mais recentemente, Haveman et al. (1995) desenvolveram um novo indicador para captar as perdas econômicas atribuídas a uma força de trabalho com estado de saúde inadequado.

Para a análise das perdas de rendimento devido às condições adversas de saúde será utilizado o método de estimação propostos por Luft (1974). Ademais, para a obtenção da equação de saúde será utilizado o modelo econômico de família (household model), desenvolvido por Becker (1964).

\subsection{Objetivos do estudo}

Considerando o pequeno número de trabalhos que têm por objetivo estimar as perdas de rendimento da força de trabalho ocasionadas por condições de saúde inadequadas, assim como dos que relacionam a falta de saneamento básico às condições de saúde, procurar-se-á oferecer uma contribuição empírica para a melhor compreensão deste tema. 
O presente trabalho visa, sobretudo, possibilitar o melhor entendimento dos efeitos positivos que os investimentos em capital humano e em infra-estrutura, especificamente quando relacionados às condições de saúde e meio ambiente, podem proporcionar para a melhoria nas condições de desenvolvimento sócio-econômico do país.

Este estudo tem como objetivo geral estimar as perdas de rendimento dos homens e mulheres adultos (18 a 65 anos) provocadas pela ausência de condições adequadas de saúde, bem como relacionar os efeitos de condições adversas de saneamento básico na saúde dos indivíduos, utilizando a Pesquisa Nacional sobre Saúde e Nutrição (PNSN) de 1989.

Especificamente pretende-se:

a) Estimar as perdas de rendimento ocasionadas pela ausência de condições adequadas de saúde; e,

b) Estimar equações de saúde para captar o impacto da infra-estrutura disponível no local de residência (esgotamento sanitário, coleta de lixo, abastecimento de água e energia elétrica) sobre a saúde dos homens e mulheres adultos. 


\section{REFERENCIAL TEÓRICO}

Neste item, apresenta-se a definição de capital humano e como foi originado este conceito. Posteriormente, será apresentado como foram desenvolvidos os indicadores sociais de produtividade do trabalho, caracterizando os primeiros estudos realizados sobre nutrição e condições de saúde, bem como o atual estágio referente aos indicadores de perdas salariais.

Finalmente, serão apresentadas algumas evidências empíricas sobre o relacionamento entre condições ambientais e condições de saúde, revendo um conjunto de trabalhos realizados no Brasil e no Exterior.

\subsection{A Origem e a definição do conceito de capital humano}

A idéia de que o investimento na força de trabalho, seja na forma de investimento em educação, treinamento ou na melhoria das condições de saúde, é uma importante variável para que um país possa atingir maior nível de desenvolvimento econômico é de grande aceitação. Entretanto, havia até a década de 60 a idéia equivocada de que o crescimento econômico estaria baseado essencialmente no capital físico, a qual foi devidamente reavaliada com o sucesso do 
Plano Marshall na Europa e os escassos resultados da ajuda externa dada aos países menos desenvolvidos ${ }^{4}$.

A injeção de capital físico (máquinas e equipamentos) não foi suficiente para reverter o péssimo padrão de produtividade econômica presentes nos países menos desenvolvidos. A lição que fica é de que o capital físico não produz crescimento satisfatório se não houver capital humano apropriado. Tanto capital físico como capital humano são essenciais. Isoladamente, nenhum dos dois é condição suficiente para um país obter um crescimento acelerado.

A partir da década de 60 surgiram estudos adotando a idéia de que o desenvolvimento econômico é um fenômeno baseado não apenas nos recursos naturais e na acumulação de capital, mas também nos investimentos incorporados à mão-de-obra. Estes estudos possuíam um enfoque macroeconômico, tendo como objetivo básico compreender os efeitos do capital humano e do estoque de conhecimentos no desenvolvimento econômico. Ocorreu, naquela época, um certo rompimento com as teorias tradicionais de crescimento econômico ${ }^{5}$ que colocavam o capital físico como o fator de produção mais importante no desenvolvimento econômico.

Neste sentido Schultz (1961), ao analisar o processo de crescimento, ampliou o conceito de capital, presente nos modelos tradicionais, incluindo o capital humano e o estoque de conhecimentos. Na visão Schultziana, recursos naturais, capital físico e mãode-obra bruta não seriam suficientes para o desenvolvimento de uma economia moderna.

\footnotetext{
4 Spanier (1991) ressalta que o Plano Marshall foi baseado na liberação de vultosos créditos financeiros dirigidos para a reconstrução das economias capitalistas européias, devastadas pela guerra. Tratava-se de uma iniciativa de fundo, destinada a materializar a estratégia da contenção. A força do dólar e o dinamismo da economia americana passariam a alicerçar o espaço geopolítico da Europa Ocidental.

5 Harrod (1939) e Domar (1946) interpretam o modelo keynesiano, que estuda a dinâmica econômica, ressaltando a relação direta entre a taxa de crescimento econômico e a taxa de poupança na economia, dividida por uma relação capital-produto constante (condição Harrod-Domar).
} 
Haveria a necessidade de investimentos em um conjunto de aptidões humanas para a alimentação da dinâmica do desenvolvimento, ou seja, do crescimento da produtividade.

Kuznets (1961) também buscou ampliar o conceito de formação de capital indicando que investimentos em saúde, educação e no homem de forma geral deveriam ser levados em consideração ao se estudar o processo de crescimento econômico.

Outro importante modelo que procura explicar o progresso técnico é o modelo de Arrow e Sheshinski, citado por Stern (1964). A idéia básica deste modelo é que com o passar do tempo um conjunto de conhecimentos é gerado através dos investimentos em novas tecnologias feitos pelas firmas. Esse conhecimento é incorporado em novas máquinas e equipamentos, de tal modo que os agentes econômicos podem ter acesso a ele com custo zero. Neste modelo o progresso técnico é explicado através da idéia de aprender fazendo (learning-by-doing).

Os modelos recentes de crescimento endógeno, elaborados no final da década de 80, evoluíram ao considerar os efeitos positivos do investimento em capital humano. Destacam-se os modelos elaborados por Romer (1986) e Lucas (1988).

Além dos estudos com enfoque macroeconômico, analisados anteriormente, surgiram trabalhos sob um enfoque microeconômico, preocupados em evidenciar como as diferenças no estoque de capital humano individual e seu crescimento podiam explicar a variação observada na estrutura de salários e na distribuição de renda pessoal. Neste tipo de análise destacam-se os trabalhos de Mincer (1958) e Becker (1964), onde o capital humano é visto como um conjunto de fatores que influenciam a produtividade do trabalho.

Mincer (1958) foi o pioneiro na analise do relacionamento da distribuição de renda com o capital humano. Em seu estudo, ele abordou a idéia de capital humano, 
estudando as diferenças individuais de renda originárias do investimento em educação. Para atingir o seu objetivo analisou os investimentos em capital humano pelo lado dos custos individuais de oportunidade e pelo lado dos rendimentos através dos diferenciais de renda entre pessoas qualificadas e não qualificadas.

De acordo com Mincer (1958) há uma grande incompreensão sobre a natureza dos gastos com educação, saúde e informações, fazendo com que os investimentos sejam feitos mais em máquinas do que em capital humano. A terra, um recurso natural, já foi considerada como um fator crítico ao crescimento econômico por David Ricardo.

Atualmente há a percepção de que a qualidade da mão-de-obra e, até mesmo, a cultura de uma nação são fatores relevantes ao se considerar o processo de desenvolvimento econômico. Admite-se, portanto, que a rápida industrialização gera aumentos de produtividade e renda. Porém, é fundamental considerar a necessidade de recursos humanos altamente qualificados.

Becker (1964) desenvolveu a Teoria do investimento em Capital Humano, que possibilitou o estudo dos efeitos da educação, saúde e outras dimensões do capital humano no rendimento e emprego dos indivíduos. Sua análise teórica permitiu a determinação dos custos e retornos do investimento no ensino básico e superior. Outra parte de seus estudos explorou a relação entre a experiência no trabalho, idade e acumulação de riqueza e obtenção de rendimento.

O investimento em capital humano, segundo Becker (1964), é dado pelo nível de saúde, educação formal, experiência e pesquisa.

De acordo com Febrero \& Schwartz (1997), na obra The Essence of Becker, Gary Becker inova na teoria econômica, propondo uma nova restrição de tempo, indica onde o mesmo pode ser alocado entre as atividades do mercado de trabalho, atividades de 
consumo e investimento em capital humano. No modelo de investimento em capital humano o custo atual não precisa ser compensado por um beneficio equivalente hoje. Em outras palavras, isto significa que os indivíduos podem comparar o valor do custo marginal do investimento em capital humano (incluindo os rendimentos) com o valor presente dos retornos futuros.

O modelo de investimento em capital humano pode explicar, entre outras coisas, por que o montante de tempo gasto em capital humano tende a declinar com a idade e as pessoas com baixa propensão a poupar tendem a investir menos em capital humano. A diferença no montante de investimento em capital humano feito pelos indivíduos provoca o aparecimento de alto grau de heterogeneidade entre os trabalhadores e a consequente diferença nos seus correspondentes rendimentos. Além disso, os processos de mensuração de riqueza baseados exclusivamente em ativos físicos e financeiros tendem a subestimar a riqueza dos agentes e das nações.

Uma das maneiras de efetuar um investimento em capital humano é investindo na melhoria da saúde. A condição de saúde é considerada um importante determinante do rendimento. A saúde, assim como o conhecimento, pode ser melhorada de diferentes formas. O declínio da taxa de mortalidade da população economicamente ativa pode ampliar o período no qual o rendimento é recebido, assim como uma melhor dieta melhora a disposição ao trabalho dos indivíduos, afetando a produtividade de trabalho.

O investimento em saúde aumenta a produtividade na mesma extensão do investimento em treinamento. Portanto, uma firma poderia investir recursos em hospitais e consultas médicas. Entretanto, apesar de algumas empresas estarem começando a investir na saúde dos seus trabalhadores, muitos investimentos em saúde são feitos fora da firma. 
Becker (1964) sempre deixou claro que, ao enfatizar a importância do investimento em capital humano, não estava desconsiderando outros fatores mas sim, contribuindo para resgatar fatores que foram ignorados por muito tempo pela teoria econômica.

\subsection{Um breve histórico do desenvolvimento dos indicadores sociais de produtividade do trabalho relacionados ao estado de saúde}

O desenvolvimento de indicadores que procuram mensurar a produtividade do trabalho a partir de variáveis relacionadas às condições de saúde abrange duas linhas de trabalho. A primeira refere-se ao conjunto de autores que tinham como objetivo primordial o desenvolvimento de trabalhos que relacionassem condições nutricionais com o nível de renda, sem contudo, se preocuparem em relacionar diretamente os efeitos das condições de saúde sobre o trabalho. Entre os autores dessa linha de pesquisa podese citar especificamente Leibenstein (1957). A segunda linha de pesquisa tem como objetivo estudar os efeitos das condições de saúde sobre o salário, construindo indicadores que possam captar as perdas salariais provocadas por condições adversas de saúde. Destacam-se nesta linha os estudos de Luft (1974) e Haveman (1995).

\subsubsection{Das condições nutricionais até as primeiras inferências sobre produtividade do trabalho}

Diversos estudos realizados sobre as condições de saúde buscaram relacionar variáveis que captassem as condições nutricionais do indivíduo e, assim, fazer inferências sobre a produtividade do trabalho e a renda. 
Sukhatme $(1977)^{6}$, citado por Aziz (1995), procurou compreender os determinantes da desnutrição, fazendo uma revisão crítica dos métodos usados para analisar a relação entre o nível de renda dos pobres e a desnutrição. Alguns estudos consideravam 2200 calorias como sendo o valor adequado para manter as pessoas nutridas enquanto que o autor, baseado no estudo "Third World Food Plan" (elaborado pela FAO), reduziu este valor para 1900 calorias. Estes dados indicaram que 30\% da população rural da Índia era subnutrida, se fosse levado em consideração o parâmetro de subnutrição apontado pelo autor.

A importância do estudo elaborado por Sukhatme (1977) consiste em apresentar evidência estatística da diminuição do nível de energia necessária para se evitar a subnutrição. Este estudo, no entanto, não analisa a produtividade do trabalho e não mostra quais os efeitos que a desnutrição poderia ocasionar sobre o salário dos trabalhadores.

Vários estudos surgiram no intuito de postular a existência da relação entre consumo de alimentos e produtividade.

Myrdal (1968) ${ }^{7}$, citado por Aziz (1995), ressalta que uma dieta deficiente reduz a habilidade dos trabalhadores, diminuindo a oferta de trabalho e a eficiência na produção. Seu estudo indica que a baixa produtividade do trabalho, por outro lado, é a maior causa dos problemas de desnutrição e subnutrição no sul da Ásia. Ele chama a atenção para o círculo vicioso pelo qual a subnutrição conduz a uma baixa produtividade, sendo que este efeito volta a provocar a subnutrição. Neste sentido, as deficiências nutricionais seriam consideradas obstáculos ao crescimento e desenvolvimento da agricultura.

6 Sukhatme, P.V. Malnutrition and Poverty. Ninth L.B. Sastri Memorial Lecture. New Delhi: Indian Agriculture Research Institute. 1977.

7 Myrdal, J. Efficiency and Productivity. Milbank Memorial Fund. v.44, p. 65-102. 1968. 
Leibenstein (1957) foi um dos primeiros a mostrar a relação entre o aumento salarial, quantidade de horas de trabalho e produtividade. Ele propôs a Hipótese da Eficiência Salarial (Efficiency Wage Hypothesis Theory). Esta hipótese pressupõe que, em baixos níveis de renda, existe uma relação positiva entre consumo de alimentos e produtividade do trabalho. $\mathrm{O}$ autor salienta que a produtividade dos trabalhadores depende da energia armazenada e da saúde, a qual depende, por sua vez, do nível de consumo (que depende da renda) e, mais diretamente, do valor nutritivo dos alimentos ingeridos. Seguindo este raciocínio, um trabalhador pode trabalhar um menor número de horas, mantendo o mesmo nível de produção, caso esteja com um alto nível de energia armazenada. Esta idéia mostra a existência de um equilíbrio entre o nível de energia absorvida por um trabalhador, sua renda e o número de horas que ele é capaz de trabalhar.

Leibenstein (1986) consolida as idéias mencionadas, evidenciando que a relação salário-produtividade poderia ser dividida em duas relações:

a) renda (salário) e nutrição; e,

b) nutrição e produtividade.

O autor ressalta, com base em vários estudos, que o valor nutritivo da dieta (calorias, proteínas, ferro e cálcio, entre outros) cresce monotonicamente com a renda. Cita, especificamente, a Food and Agriculture Organization (FAO), que estimou as calorias consumidas em vários países, encontrando uma alta correlação entre baixas calorias consumidas e baixas rendas per capita.

No que se refere à relação entre caloria ingerida e produtividade, Liebenstein argumenta que a quantidade de calorias necessárias a uma determinada pessoa depende da sua estrutura física e da natureza da sua atividade. Os experimentos fisiológicos 
seriam capazes de calcular as calorias necessárias a um indivíduo de acordo com as atividades exercidas.

Para exemplificar essa idéia, o autor fez o seguinte raciocínio. Primeiramente, assumia que um indivíduo dormia oito horas por dia, ficando dezesseis horas acordado, sendo necessárias 1500 calorias para o perfeito funcionamento do seu metabolismo. Adicionando, aproximadamente, 100 calorias por hora de trabalho moderado, num período de quatro horas, 20 calorias por doze horas de relaxamento e mais 1500 calorias para o metabolismo, ter-se-ia um total de 2140 calorias necessárias para um trabalhador suportar quatro horas de trabalho por dia. Se o trabalhador adicionasse 320 calorias à sua dieta, ter-se-ia um total de 2460 calorias, possibilitando que ele trabalhasse oito horas por dia nas mesmas condições. Isto implicava que, se o empregador pagasse inicialmente um determinado salário para o trabalhador, que fosse suficiente apenas para obter uma dieta de 2140 calorias, o trabalhador poderia praticamente dobrar sua capacidade efetiva de trabalho, se o empregador pagasse um salário que lhe permitisse a compra de uma dieta de 2460 calorias.

De acordo com Bliss \& Stern (1978), a relação produtividade-consumo (aumento da produtividade via aumento do consumo de alimentos) e sua influência no salário dos trabalhadores tem sido examinada por muitos autores. Mirless (1976) e Stiglitz (1976) discutiram a relação produtividade-consumo influenciando a alocação ótima do trabalho e o salário sombra. O estudo de Bliss \& Stern (1978) incorporou muitas das idéias contidas nos trabalhos de Leibenstein (1957), Mirlees (1976) e Stiglitz (1976), testando a Hipótese da Eficiência Salarial. 


\subsubsection{A construção de novos indicadores sociais de produtividade do trabalho}

O desenvolvimento de estudos com o propósito de analisar o impacto das condições de saúde sobre o salário surgiu no início da década de 60 .

O trabalho sobre determinação da renda realizado por Morgan et al. $(1962)^{8}$, citado por Luft (1974), utiliza uma amostra de indivíduos adultos (com idade entre $18 \mathrm{e}$ 64 anos) dos Estados Unidos no ano de 1967, estratificados por sexo, raça e estado de saúde. A partir deste conjunto de informações foram estimadas equações de salário, participação na força de trabalho, emprego, entre outras, sendo que os coeficientes derivados da análise da amostra das pessoas em bom estado de saúde foram, posteriormente, utilizados para os valores observados da amostra das pessoas doentes, supondo que as pessoas doentes estivessem em boas condições de saúde. Neste estudo os autores concluíram que o estado de saúde foi importante na estimação da participação na força de trabalho, horas trabalhadas por ano e taxa de salário horária, com grande impacto sobre a taxa de participação na força de trabalho. Os autores também procuraram estimar o custo da incapacidade. Entretanto, o pequeno número de observações presentes na amostra utilizada fez com que poucas pessoas fossem incluídas como incapazes, afetando os resultados do estudo.

Diversos outros estudos como, por exemplo, o de Parnes \& Meyer (1971) ${ }^{9}$, citado por Luft (1974) e Davis (1972), indicaram que a saúde é importante para a participação na força de trabalho, semanas trabalhadas, taxa de desemprego e horas trabalhadas.

8 Morgan J.N, David M.H., W.J Cohen \& Brazer, H.E. Income and Welfare in United Estates. New York, McGraw-Hill, 1962.

9 Parnes, H. S.; J. Meyer. Withdrawal from the labor force by middle aged men, 1966-67. Columbia, Ohio: Center for human resource research, Ohio State University. Jan, 1971. 
Bowen \& Finagan (1969) explicaram os possíveis fatores que determinavam a participação na força de trabalho em grupos específicos da população, incluindo homens com idade entre 25 e 54 anos, mulheres casadas com idade entre 14 e 54 anos, pessoas idosas com idade acima de 54 anos e jovens com idade entre 14 e 24 anos. Os autores desenvolveram uma estrutura conceitual para determinar a taxa de participação na força de trabalho. De maneira geral, eles destacaram a importância do estado de saúde na determinação da participação na força de trabalho.

Pode-se dizer que uma das primeiras economistas que procurou estimar as perdas agregadas dos salários devido a doenças, por meio de indicadores de morbidade $\mathrm{e}$ mortalidade, foi D. P. Rice. Uma das dificuldades enfrentadas por ela foi a inexistência de estimativas, a não ser aquelas feitas pelo economista $J$. N. Morgan, dos efeitos da incapacidade sobre o mercado de trabalho.

Luft (1974) teve como interesse primário estimar a importância dos efeitos da saúde sobre o salário. O estudo considera as diferenças nos valores das variáveis dependentes para duas populações definidas pelo estado de saúde (doentes e saudáveis). Quatro amostras categorizadas por raça e sexo foram divididas de acordo com o grupo de pessoas doentes ou saudáveis.

Rice et al. (1985) estimaram para os Estados Unidos, a perda de produtividade devida a problemas de saúde, caracterizando-as como perdas salariais. O indicador proposto pelos autores tinha como propósito mensurar como o salário individual responderia a incapacidade/limitação de saúde, refletindo a preferencia individual por trabalho versus lazer ${ }^{10}$. A perda salarial estimada foi de 67,8 bilhões de dólares em 1980 ou aproximadamente $1,7 \%$ do PNB.

10 No capítulo dedicado à metodologia será feita uma descrição detalhada deste indicador comparativamente ao indicador utilizado neste estudo. 
Outro importante e recente trabalho realizado sobre as estimativas das perdas de rendimento devido as condições de saúde é o trabalho realizado por Haveman et al. (1995), que propõe a utilização de um novo procedimento metodológico para determinação das referidas perdas. Os autores elaboram um novo conceito de perdas salariais denominado perda da capacidade de rendimento, que é a diferença entre o montante de dinheiro que as pessoas potencialmente poderiam ganhar se estivessem livres de inabilidade ou limitações de saúde e o que realmente ganham. Este estudo analisou a perda de capacidade de rendimento da população americana em 1973 e 1978. No ano de 1973 a perda de capacidade de rendimento ficou em 5,3\% do Produto Nacional Bruto e no ano de 1988 a mesma perda foi estimada em 4,5\%.

É conveniente ressaltar que os trabalhos de Luft (1974) e Haveman et al. (1995) constituem a base para os procedimentos metodológicos adotados neste estudo ${ }^{11}$. O trabalho de Harold S. Luft é fundamental para a determinação das variáveis dependentes e explicativas do modelo adotado. Além disso, as perdas de rendimento por hora serão obtidas através dos procedimentos adotados por Luft (1974). Entretanto, para a obtenção das perdas de rendimento por ano será utilizado o conceito de capacidade potencial de horas de trabalho proposto por Haveman (1995).

\subsection{Algumas evidências empíricas sobre as condições ambientais e seu relacionamento com o estado de saúde}

Nesta seção faz-se referência a trabalhos que enfatizam a teoria do capital humano, particularmente na área ambiental e de saúde. Neste grupo destacam-se, também, os estudos que relacionam outras variáveis, como educação e saneamento básico.

\footnotetext{
11 No capítulo referente a metodologia será realizada uma descrição precisa sobre os procedimentos adotados para se estimar as perdas de rendimento provocadas por condições adversas de saúde.
} 
Observa-se que os estudos que abordam especificamente as condições ambientais e a saúde são poucos. Trabalhos recentes de Kassouf (1995), Martins (1995) e Seroa da Motta \& Mendes (1995) analisam a relação entre meio ambiente e saúde no Brasil.

Estudos que relacionam o grau de escolaridade com a saúde são mais frequentes na literatura internacional. Dentro desta linha de pesquisa, Merrick (1985) analisou o impacto da escolaridade e da presença de água encanada sobre a mortalidade infantil no Brasil durante os anos 70 .

Para alcançar o seu objetivo o autor elaborou um modelo recursivo composto por três equações. A primeira equação teve por intento especificar a variável endógena rendimento do marido em termos de sua educação e do valor do imposto de renda per capita. A educação refletiria a influência das características individuais sobre o rendimento. A segunda equação indicava como variável dependente o acesso doméstico à água encanada, que era função da educação do marido e da esposa, rendimento do marido e o nível de oferta de água da comunidade. Por último, a terceira equação representava a mortalidade infantil como função da educação do casal, rendimento do marido e nível de oferta de água na comunidade. As principais conclusões do autor foram de que a educação materna e paterna tiveram um maior efeito (negativo) na mortalidade infantil. Além disso, o seus resultados demostraram que o acesso a água encanada teve um efeito negativo significativo, mas secundário na mortalidade infantil.

Thomas \& Strauss (1990) tiveram por objetivo básico estudar três maneiras pelas quais a educação materna afetaria a saúde da criança. Um melhor nível educacional materno traria como resultado o aumento da renda, o melhor processamento de informações e maior interação com os serviços comunitários. Esses três efeitos contribuem para o melhor crescimento das crianças. Este estudo abrangeu o setor urbano e rural da região Nordeste, além dos Estados do Rio de Janeiro, Rio Grande do Sul, Paraná e Brasília que formaram, pela classificação dos referidos autores, a região 
Sul. Em conclusão, os autores ressaltaram um forte efeito positivo da educação materna sobre a altura das crianças no setor urbano e rural da região Nordeste. $\mathrm{O}$ aumento na quantidade e qualidade dos serviços de infra-estrutura teria um efeito positivo na saúde das crianças. Por fim, os autores apontaram evidências da significativa interação entre educação materna e a extensão da infra-estrutura para a comunidade, existindo uma interação positiva com os serviços de esgoto.

Um importante estudo elaborado por Barrera (1990) analisou se o grau de escolaridade da mãe afetava a saúde das crianças em diferentes faixas de idade nas Filipinas. Este estudo baseou-se no modelo desenvolvido por Becker (1965), que coloca a saúde como um bem que não é de mercado, mas sim um bem doméstico. Neste estudo o autor concluiu que a educação materna afeta positivamente a saúde da criança, principalmente as crianças em idade pré-escolar. Outro aspecto importante refere-se ao fato de que o padrão de interação entre a educação materna e o programa de saúde pública sugere que a educação materna afeta a saúde da criança, provocando um efeito eficiência, afetando a produtividade dos insumos utilizados na saúde, e um efeito alocativo pela diminuição dos custos da informação.

Nesta mesma linha de pesquisa Kassouf (1995) estudou o efeito da interação entre a educação materna e o saneamento básico (água encanada e esgoto) sobre a saúde das crianças brasileiras em diferentes faixas de idade. Este estudo também se baseou no modelo proposto por Becker (1981). Os resultados indicaram que o nível educacional da mãe, medido em número de anos de escolaridade, afeta de maneira significativa a saúde das crianças. O saneamento básico mostrou um grande efeito positivo sobre a saúde das crianças. Por fim a autora conclui que o saneamento básico inadequado, agravado pelo baixo nível educacional, e portanto higiene precária, tornam o ambiente doméstico propiciador de altos riscos para a saúde da criança. 
Martins (1995) analisou o impacto do saneamento básico na saúde da população em três municípios do Vale do Ribeira (região Sudeste do Estado de São Paulo). Outros aspectos analisados referem-se aos custos do tratamento das doenças relacionadas com a falta de infra-estrutura e os custos de serviços. $\mathrm{O}$ autor traçou um perfil dos moradores através das características das moradias, faixa salarial, ocupação e escolaridade. Também fez um levantamento do número de atendimentos ambulatoriais feitos pelas unidades de saúde da região e das internações dos moradores nos hospitais. $\mathrm{O}$ estudo indicou que as regiões com saneamento básico adequado contribuem com apenas $16 \%$ dos casos de doenças de veiculação hídrica comparativamente às regiões sem saneamento. Além disso, constata que nas localidades sem água encanada, o custo do tratamento com saúde varia entre US $\$ 33,02$ e US\$ 79,45 por habitante/ano. Já nas localidades com água tratada a despesa com saúde cai para US\$14,17 por habitante/ano e naquelas que dispõem de saneamento básico o custo é menor ainda, em torno de US\$11.

Seroa da Motta \& Mendes (1995) estimaram os gastos médicos e a produção sacrificada decorrentes da incidência de doenças associadas à poluição hídrica doméstica e a determinação da incidência de mortalidade e morbidade das doenças. Para alcançar o objetivo proposto os autores buscaram desenvolver uma função que permitiria indicar, para cada ano, o nível de incidência das doenças associadas à poluição hídrica. As simulações realizadas demonstraram que, se toda a população urbana tivesse acesso a sistemas de esgoto, aproximadamente 60\% dos casos de óbitos (mortalidade) registrados não ocorreriam, enquanto no caso de morbidade esta porcentagem chegaria a $90 \%$.

Esses trabalhos mostram a importância da realização de estudos na área ambiental pois demonstram que as condições de saneamento básico são relevantes para a redução e controle das doenças estudadas (cólera, infecções gastrintestinais, febre tifóide, poliomielite, amebíase, esquistossomose e shiguilose). 
Ainda de acordo com Seroa da Motta \& Mendes (1995), a degradação da qualidade da água está prejudicando os serviços de abastecimento de água. Os serviços de coleta de lixo e esgotamento sanitário permitiriam a redução das doenças ambientais, uma vez que mais de $80 \%$ da população urbana já possui serviços de abastecimento de água adequado. 


\section{MODELOS}

O objetivo básico deste item é detalhar os modelos que definiram a escolha da metodologia a ser seguida neste trabalho.

Primeiramente, serão analisados os principais modelos de estimação das perdas de rendimento devidas às condições adversas de saúde. Posteriormente, será analisado o modelo de Becker que possibilitará o estudo do relacionamento das condições de saúde e infra-estrutura, mais especificamente, os efeitos da quantidade e qualidade dos serviços de saneamento básico sobre a saúde dos indivíduos. Estes modelos são de fundamental importância para a compreensão dos diversos procedimentos metodológicos adotados no presente estudo.

O primeiro trabalho a ser destacado é o de Luft (1974), que teve como objetivo básico estudar os efeitos da saúde do trabalhador sobre o seu rendimento. Pode-se dizer que este estudo contribui de maneira decisiva para todos os estudos que tiveram o mesmo objetivo básico. Outros dois importantes estudos serão analisados por serem recentes na literatura internacional referente aos métodos de estimação de perdas de rendimento. O mais importante deles é o estudo elaborado por Haveman et al. (1995) que apresenta o conceito de Perda de Capacidade de Rendimento (PCR). Este conceito tenta corrigir alguns problemas metodológicos apresentados pelo conceito de Perda de Rendimento (PR) criado por Rice et al. (1985). 
Primeiramente, apresentar-se-ão os procedimentos metodológicos elaborados por Luft (1974). Posteriormente, serão analisados os dois conceitos para a estimação de perdas de produtividade: Perda da Capacidade de Rendimento (PCR), proposto por Haveman et al. (1995), e Perdas de Rendimento (PR), elaborado por Rice et al. (1985).

\subsection{O modelo de Luft}

Os objetivos básicos de Harrod S. Luft no seu estudo The impact of Poor Health on Earnings foram o de analisar os efeitos das condições de saúde do trabalhador nos vários componentes do rendimento, analisar as diferentes maneiras pelas quais as limitações na saúde afetam os diferentes grupos sociais e, finalmente, estimar as perdas de rendimento para os diferentes grupos sociais, assim como estimar as perdas totais devido as condições adversas de saúde.

Luft (1974) utilizou a pesquisa Survey of Economic Oportunity (SEO). Esta pesquisa é uma pesquisa nacional familiar que apresenta uma amostra para a população branca e outra amostra realizada em áreas onde os habitantes são, na sua maioria, não brancos. Os indivíduos pertencentes a amostra também foram divididos de acordo com o estado de saúde. Os doentes foram enquadrados em várias categorias, de acordo com o grau de incapacidade de realizar trabalho. Haviam alguns indivíduos que estavam impedidos de trabalhar e outros que podiam realizar parcialmente algum tipo de atividade. Além disso, os coeficientes derivados da amostra dos indivíduos saudáveis foram combinados com os valores observados da amostra dos indivíduos doentes para estimar o comportamento destas pessoas se elas estivessem saudáveis.

Os comentários sobre a participação da força de trabalho no mercado e a definição das variáveis dependentes elaborados no estudo de Bowe \& Finegan (1969) influenciaram de maneira decisiva os procedimentos metodológicos realizados por Luft 
(1974). Bowe \& Finegan (1969) fizeram uma ampla analise dos componentes do rendimentos da força de trabalho, ajudando na definição das principais variáveis a serem estudadas neste tipo de trabalho.

Ao construir o seu modelo Luft (1974), procurou determinar um grande número de variáveis explicativas, aproveitando a enorme gama de informações presentes na SEO. As variáveis sobre estado de saúde, ponderadas pelo peso de cada indivíduo na amostra, serviram para determinar a população de pessoas saudáveis e a população de pessoas inabilitadas, indicando a carência de saúde dos indivíduos. Além disso, a SEO permitiu a separação da amostra por sexo (homem e mulher) e raça (negro ou branco).

O procedimento de estimação adotado neste trabalho foi, de certa forma, bastante criativo. Primeiramente, foram estimadas equações para pessoas saudáveis e pessoas doentes. Então foi calculada a diferença total entre as médias das variáveis dependentes para as pessoas saudáveis e doentes. Esta diferença total não era uma medida precisa para mensurar o impacto da doença tendo em vista que as duas populações poderiam diferir em relação a outras características que não o estado de saúde. Para corrigir esta situação os coeficientes estimados para as pessoas saudáveis foram utilizados na amostra de doentes para captar qual o rendimento que eles poderiam obter se tivessem os mesmos coeficientes da população saudável. Foi obtido assim, uma diferença ajustada que teve por objetivo captar perdas provocadas exclusivamente por doenças. Este procedimento foi importante para o desenvolvimento de um método de estimação para as perdas de rendimento. Pode-se dizer que o seu estudo tornou-se fundamental para o desenvolvimento de novos métodos de estimação. Além disso, as informações geradas por este procedimento permitiram ainda a comparação do impacto de uma saúde inadequada para os diferentes grupos sociais, ampliando ainda mais a relevância dos conclusões do seu trabalho. 
Para estimar as perdas de rendimento total o autor utilizou uma combinação de procedimentos, possibilitando dois métodos distintos para captar as perdas de rendimentos das pessoas com condições de saúde adversas (métodos A e B).

O montante total de perda de rendimento foi definido como sendo a soma do rendimento perdido devido à não participação na força de trabalho e o rendimento perdido pelas pessoas que participam da força de trabalho mas que recebiam menos do que elas poderiam receber se estivessem bem durante um determinado ano base. A segunda parte deste conceito foi estimada de duas maneiras diferentes. A primeira maneira de se proceder este calculo é multiplicar o total da força de trabalho pela estimativa das perdas de rendimento para o ano base (método A). A outra maneira utiliza estimativas separadas para calcular as semanas perdidas e o rendimento perdido por semana (método B). Vale ressaltar que as perdas de rendimento encontrados no método A e no método B tiveram uma variação de apenas $1 \%$.

Ressalte-se que os procedimentos adotados podem ser considerados relativamente simples. Entretanto, pode-se dizer que o estudo teve o seu padrão de qualidade aumentado pelo grande número de pessoas incluídas na amostra, bem como um conjunto de informações que permitiram a construção de uma método de estimação eficiente.

\subsection{O modelo de Haveman derivado do modelo de Rice}

Neste item serão apresentados a definição dos conceitos bem como os procedimentos para estimação das Perdas de Capacidade de Rendimento (PCR) e Perdas de Capacidade (PC), elaborados, respectivamente, por Haveman (1995) e Rice et al. (1985). O objetivo básico é o de esclarecer as diferenças entre os dois conceitos, assim 
como evidenciar as principais vantagens na adoção do indicador de Perda da Capacidade de Rendimento (PCR).

\subsubsection{O Conceito de perda de capacidade de rendimento}

O objetivo do conceito de perdas de produtividade é o de capturar a redução na capacidade da força produtiva causada por inabilidade e/ou limitações de saúde. De acordo com Haveman et al. (1995), o conceito de perda da capacidade de rendimento (PCR) é definido como sendo a diferença entre a capacidade de rendimento atual da população economicamente ativa (refletindo as limitações atuais que restringem a capacidade de trabalho) e a capacidade de rendimento desta população, assumindo ausência de limitações de saúde.

Existem duas partes a serem analisadas nesta definição. A primeira refere-se à capacidade atual de rendimento (CAR) dos membros da população economicamente ativa, que é medida como o valor (rendimentos totais) que poderia ser gerado se eles estivessem trabalhando o número máximo de horas por ano permitido pelas suas atuais condições de saúde. O salário refletiria as limitações de saúde da população.

A idéia básica presente na definição da CAR é que ela refletiria o rendimento potencial que um determinado trabalhador poderia obter, levando-se em consideração as suas condições atuais de saúde. Este conceito pode ser analisado como sendo a capacidade produtiva da força de trabalho agregada.

A segunda parte presente no conceito de PCR é a capacidade potencial de rendimento (CPR) que é medida como o valor produzido (ou rendimento total) que as pessoas incluídas na população economicamente ativa poderiam gerar se trabalhassem 
na sua capacidade total (tempo integral). A taxa salarial estimada seria aquela que poderia ser paga se não estivessem presentes limitações de saúde.

$$
\begin{aligned}
& \text { Algebricamente tem-se, } \\
& \mathrm{PCR}_{i}=\mathrm{CPR}_{i}-\mathrm{CAR}_{i}
\end{aligned}
$$

ou

$$
\mathrm{PCR}_{i}=w_{i}^{P} \bar{H}_{i}^{P}-w_{i}^{A} \bar{H}_{i}^{A},
$$

onde, $w^{P}$ é o salário potencial com saúde, $\bar{H}^{P}$ é a capacidade potencial de horas de trabalho se saudável, $w^{A}$ é o salário atual no atual nível de limitação de saúde (se houver), e $\bar{H}^{A}$ é a capacidade atual de horas.

\subsubsection{O conceito de perda rendimento}

O conceito de perda salarial surgiu com o trabalho realizado por Rice et al (1985). Apesar de possuir uma série de desvantagens comparativamente ao conceito de perda de capacidade de rendimento elaborado no estudo de Haveman et al. (1995), podese salientar que ele tem um importante papel no desenvolvimento de metodologias que visem a estimação de perdas de rendimento ocasionadas por limitações de saúde.

A perda de rendimento $\left(\mathrm{PR}_{i}\right)$ é definida como sendo a diferença entre uma estimativa individual de rendimento potencial $\left(\mathrm{RP}_{i}\right)$ na ausência de doença e o rendimento atual $\left(\mathrm{RA}_{i}\right)$. 
Algebricamente, observa-se:

$$
\mathrm{PR}_{i}=\mathrm{RP}_{i}-\mathrm{RA}_{i}
$$

ou

$$
\mathrm{PR}_{i}=\mathrm{PCR}_{i}=w_{i}^{P} H_{i}^{P}-w_{i}^{A} H_{i}^{A},
$$

onde $H_{i}^{P}$ são as horas de trabalho com saúde e $H_{i}^{A}$ as horas atuais pagas à força de trabalho.

De qualquer modo a equação (4) não é estimada de fato. O procedimento adotado seria multiplicar o total de dias de trabalho perdidos pela rendimento médio do conjunto da população que trabalha em tempo integral o ano inteiro. Este procedimento seria equivalente a :

$$
\mathrm{PR}_{i}=w_{i}^{F}\left(H_{i}^{F}-H_{i}^{A}\right),
$$

onde $w_{i}^{F}$ e $H_{i}^{F}$ são, respectivamente, a taxa salarial e horas pagas a força de trabalho que trabalha em tempo integral o ano todo.

\subsection{As similaridades e diferenças entre os modelos de perdas de rendimento}

Existem diversas diferenças entre os três modelos apresentados no estudo. A primeira e a mais importante diferença refere-se ao procedimento de estimação. 
No modelo de Luft os procedimentos de estimação diferem em função dos mecanismos adotados para se chegar na perda de rendimento em valores monetários.

Luft (1974) calculou os coeficientes da amostra dos indivíduos doentes para estimar o comportamento destas pessoas se elas estivessem saudáveis. Os modelos de Rice e Haveman utilizam procedimentos distintos criando, respectivamente, os conceitos de Perda de Rendimento (PR) e Perda de Capacidade de Rendimento (PCR).

Vale destacar que o modelo de Haveman (1995) é um aperfeiçoamento do modelo de Rice. Observa-se que Haveman et al. (1995) procuraram evitar algumas distorções nos procedimentos metodológicos adotados por Rice (1985).

O modelo de Rice pressupõe implicitamente que as doenças e a incapacidade não afetam o salário isto é, $w_{i}^{A}=w_{i}^{F}$. Esta pressuposição de igualdade é questionável sob dois aspectos. Para indivíduos que não estão na força de trabalho paga $\left(H_{i}^{A}=0\right)$, as equações (4) e (5) tornam-se idênticas. Pressupondo-se que o salário dos indivíduos sem doenças ou em estado de saúde normal, é igual ao daqueles que trabalham em tempo integral o ano inteiro, então $w_{i}^{P}=w_{i}^{F}$. Esta pressuposição pode ou não ser verdadeira, dependendo das características do capital humano e das preferências dos dois grupos.

O segundo problema surge do fato de Rice et al. (1985) ignorarem as perdas provocadas pelo trabalho das pessoas que trabalham apenas parte do tempo disponível. Apenas os dias perdidos são computados e os dias de trabalho em tempo parcial são contados como dias perdidos integralmente. Isto significa que o trabalho realizado em tempo parcial não é captado pela metodologia perdas de rendimento.

$\mathrm{O}$ terceiro problema é o mais sério. Para calcular $\mathrm{RP}_{i}$ os autores pressupõem que, na ausência de doenças ou incapacidade, todos os trabalhadores poderiam trabalhar 
integralmente o ano inteiro. Esta pressuposição é incorreta, tendo em vista que diversas pessoas trabalham apenas em tempo parcial ou estão desempregadas.

Neste estudo as estimativas das perdas de rendimento serão efetuadas a partir do modelo de Luft devido a sua melhor adequação às variáveis presentes na Pesquisa Nacional sobre Saúde e Nutrição.

\subsection{O modelo de Becker}

Becker $(1965,1981)$ destacou-se ao introduzir a alocação de tempo e atividades produtivas do domicílio na teoria do consumidor.

Pressupõe-se que o indivíduo maximiza a função de utilidade $(U)$ dada por,

$$
U=U\left(C, H, t_{l}\right)
$$

onde $C$ são bens consumidos, $H$ é a saúde e $t_{l}$ é o tempo de lazer.

A saúde $(H)$ é um bem produzido no domicílio, a qual depende da alimentação $(C)$, consumo de cigarros, bebidas, entre outros; da infra-estrutura básica de saneamento (I), como água encanada, sistema de esgoto, coleta de lixo entre outros; insumos de saúde $(Y)$, como consultas médicas e medicamentos; tempo de lazer $\left(t_{l}\right)$; e outras variáveis $(Z)$, como idade, escolaridade entre outros fatores.

$$
H=H\left(C, I, Y, t_{l}, Z\right)
$$

O indivíduo se depara ainda com a seguinte restrição de tempo: 


$$
T=t_{l}+t_{w}
$$

onde $T$ é o tempo total disponível, $t_{l}$ é o tempo de lazer e $t_{w}$ é o tempo gasto no mercado de trabalho.

A restrição orçamentaria incorpora o gasto total na compra de bens de mercado e insumos de saúde que, por sua vez, deve se igualar à renda total recebida no mercado de trabalho mais a renda não salarial. Observa-se, portanto a seguinte equação:

$$
P_{c} C+P_{y} Y=w t_{w}+v
$$

onde $P_{c}$ e $P_{y}$ são os preços dos bens de mercado e insumos de saúde, respectivamente, $w$ é o salário por hora de trabalho, $v$ é a renda não salarial.

Designando a restrição de tempo como:

$t_{w}=T-t_{l}$

Pode-se combinar as restrições de tempo e renda numa única restrição.

Substituindo a equação acima na restrição de renda, obtém-se:

$$
P_{c} C+P_{y} Y=w\left(T-t_{l}\right)+v
$$

ou, expressando de outra forma:

$$
P_{c} C+P_{y} Y+w t_{l}=w T+v=S
$$


onde, $S$ representa a renda total obtida se todo o tempo fosse alocado no mercado de trabalho.

A maximização da função de utilidade (6) sujeita à função de produção de saúde (7) e a restrição de renda total (12) fornece a função de demanda na forma reduzida, isto é,

$$
H=H^{\prime}\left(P_{c}, P_{y}, I, W, S, Z\right)
$$




\section{METODOLOGIA}

\subsection{Base de dados}

O presente estudo tem por base as informações presentes na Pesquisa Nacional sobre Saúde e Nutrição (PNSN) realizada pelo Instituto Nacional de Alimentação e Nutrição (INAN), Fundação Instituto Brasileiro de Geografia e Estatística (IBGE) e Instituto de Planejamento Econômico e Social (IPEA), no ano de 1989. O objetivo desta pesquisa é avaliar o estado nutricional da população, utilizando medidas antropométricas de peso e altura, com base nos padrões de referência recomendados pela Organização Mundial de Saúde (OMS). A PNSN possui informações em nível individual, incluindo uma amostra de 17.920 domicílios, com cerca de 63.000 indivíduos, em 363 municípios.

Os questionários desta pesquisa são divididos em dois conjuntos de informações:

a) características demográficas básicas;

b) características de nutrição e saúde.

As características demográficas básicas compreendem as informações sobre a população, condições de habitação e instrução e participação da mão-de-obra no mercado de trabalho. Já as características de nutrição e saúde englobam as informações 
referentes a antropometria e sintomas e sinais de saúde, acesso a serviços de saúde, histórico obstétrico da mulher e aleitamento materno. Ressalte-se que o nível de desagregação na PNSN é bastante amplo, o que possibilita a realização de análises detalhadas.

Embora a PNSN forneçam dados de boa qualidade, é necessário salientar que ela têm sido pouco explorada em pesquisas econômicas. Também, torna-se importante ressaltar que alguns procedimentos efetivados na metodologia de seleção e definição das variáveis impõem a este estudo algumas limitações na análise dos resultados, que são:

a) As pesquisas foram realizadas no ano de 1989, originando dados do tipo cross section. Este fato impede o acompanhamento do grupo de indivíduos incluídos na amostra ao longo do tempo;

b) O processo de coleta de dados pode favorecer a subestimação da renda total declarada pelos indivíduos entrevistados. A aceleração do processo inflacionário assim como a coleta de informações em um determinado ponto no tempo são fatores que podem afetar a declaração precisa dos rendimentos por parte dos indivíduos;

c) A exclusão da área rural da Região Norte.

\subsection{A utilização de medidas antropométricas para se captar o estado de saúde}

$\mathrm{Na}$ literatura existem diversos indicadores que visam mensurar o estado de saúde dos indivíduos. De acordo com Kassouf (1993) os principais indicadores são mensurados por: a) medidas clínicas; b) incapacidade para executar atividades normais;

c) sintomas de doenças; e, d) medidas antropométricas. Além desses indicadores, 
observa-se que os primeiros trabalhos sobre saúde e nutrição utilizavam os indicadores que levavam em consideração a quantidade de energia armazenada ou a quantidade de energia gasta. Estes indicadores geram problemas referentes à inexistência de critérios precisos na determinação de quantidade de energia gasta ou armazenada por um indivíduo em perfeito estado de saúde, além de não levarem em consideração as flutuações que podem ocorrer no balanço energético dos indivíduos ao longo da vida.

De acordo com James et al. (1988), o Subcomitê de Nutrição e Saúde e o Grupo Consultivo Internacional de Energia e Dieta identificaram a necessidade de uma metodologia para diagnosticar a proporção de pessoas com problemas nutricionais na população adulta. É certo que atualmente existem mecanismos precisos para se mensurar a gordura corporal. Entretanto, estes mecanismos são complexos e custosos, tendo aplicação para uso clínico e individual. Desta forma, ocorreu o desenvolvimento de um método indireto baseado na relação do peso $(\mathrm{P})$ e estatura (E) do indivíduo observado.

Os estudos realizados pelo pesquisador francês Quetelet, no final do século passado, indicaram ser a relação entre o peso e o quadrado da altura (peso expresso em quilogramas e estatura em metros) um indicador que, isoladamente, permite a avaliação do estado nutricional dos indivíduos adultos, em nível epidemiológico. Este indicador é conhecido como Índice de Massa Corporal (IMC).

O IMC respeita alguns importantes critérios de qualidade. A sua precisão não varia ao se considerar pessoas baixas ou altas.

Vale ressaltar que a escolha do ponto de corte do IMC para a classificação de baixo e alto peso é matéria de amplo debate entre os pesquisadores internacionais. É certo porém, que diversos estudos epidemiológicos [Jarret et al. $(1982)^{12}$, Lew

$\overline{12}$ Jarret, R. J et al. Weigh and mortality in the Whitehall study. Br Med. v. 285, p.535-537. 1982. 
$(1985)^{13}$, Sorlie (1980) ${ }^{14}$ ], citados pelo INAN (1991), vêm indicando uma associação entre os valores extremos de peso relativo (IMC $<20$ e IMC $>30$ ) e a mortalidade em adultos.

Waaler (1984) $)^{15}$, citado por INAN/IBGE/IPEA (1989), estudou as causas de mortalidade para indivíduos obesos e magros na Noruega, indicando que as causas de morte associadas com IMC abaixo de 20 foram tuberculose, câncer pulmonar e doenças pulmonares obstrutivas, enquanto as causas de mortalidade associadas com IMC maior que 25 foram doenças cardiovasculares, diabetes e câncer de cólon. Entretanto, pode-se dizer que são raros os estudos que relacionam as causas de mortalidade para os indivíduos obesos associadas com o IMC.

De acordo com Monteiro (1995), o Comitê de Especialistas da Organização Mundial de Saúde (OMS) concluiu que o percentual de indivíduos que seriam, por constituição física magros em uma população representaria cerca de 3\% a 5\%.

\subsection{A composição da amostra da PNSN: Uma análise da dimensão do problema nutricional de adultos no Brasil}

De acordo com a Figura 2 e tomando-se como referência os pontos de corte propostos pela OMS, a população brasileira adulta apresenta alta prevalência de baixo peso (IMC < 20), sobrepeso (IMC > 25) e obesidade (IMC >30), com uma taxa de $48,9 \%$ da população estimada. Somente $45,4 \%$ das mulheres e $57 \%$ dos homens são considerados normais.

\footnotetext{
${ }^{13}$ Lew E. A.; Garfinkel L. Variations in mortality by weight among 750.000 men and women. J Chron Dis, v. 32, P. 563-576, 1979.

${ }^{14}$ Sorlie P. Body build and mortality. The Framingham study. JAMA. v. 243, p.1828-1831, 1980.

${ }^{15}$ Waaler H. Height, weight and mortality: The norwegian experience. Acta Med Scand Suppl. v. 679, p.1$56,1984$.
} 


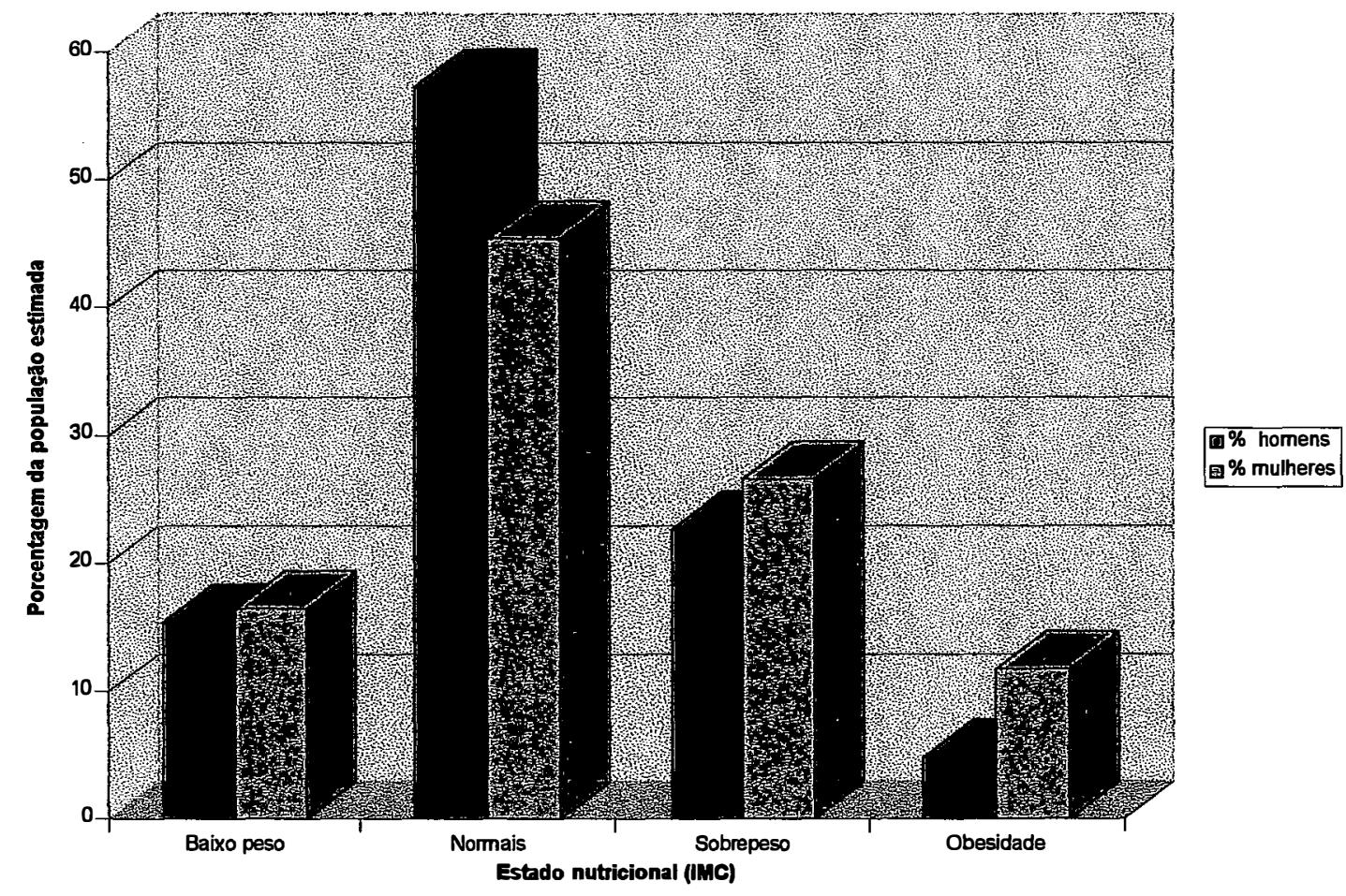

Figura 2 - Prevalência (\%) de baixo peso, sobrepeso e obesidade, segundo sexo. Brasil, 1989.

Aproximadamente 27 milhões de adultos brasileiros apresentam algum grau de excesso de peso. A obesidade, excesso de peso acentuado, atinge $8 \%$ da população, o que equivaleria a 6,8 milhões de indivíduos obesos.

Os casos de sobrepeso e obesidade são mais frequentes entre as mulheres do que entre os homens. Os casos de sobrepeso e obesidade no sexo feminino atingem $38,2 \%$ da população estimada, cerca de 16 milhões de pessoas, enquanto que a participação masculina fica em $27,4 \%$ da população, equivalente a 11 milhões. A maior prevalência de excesso de peso em mulheres é tendência mundial.

A Figura 3 demonstra que a freqüência de sobrepeso e obesidade para adultos eleva-se gradativamente até a faixa etária 45-54 anos. Nessa faixa etária encontra-se a 
maior prevalência de excesso de peso, quando $37 \%$ dos homens e $55 \%$ apresentam peso acima dos limites normais.

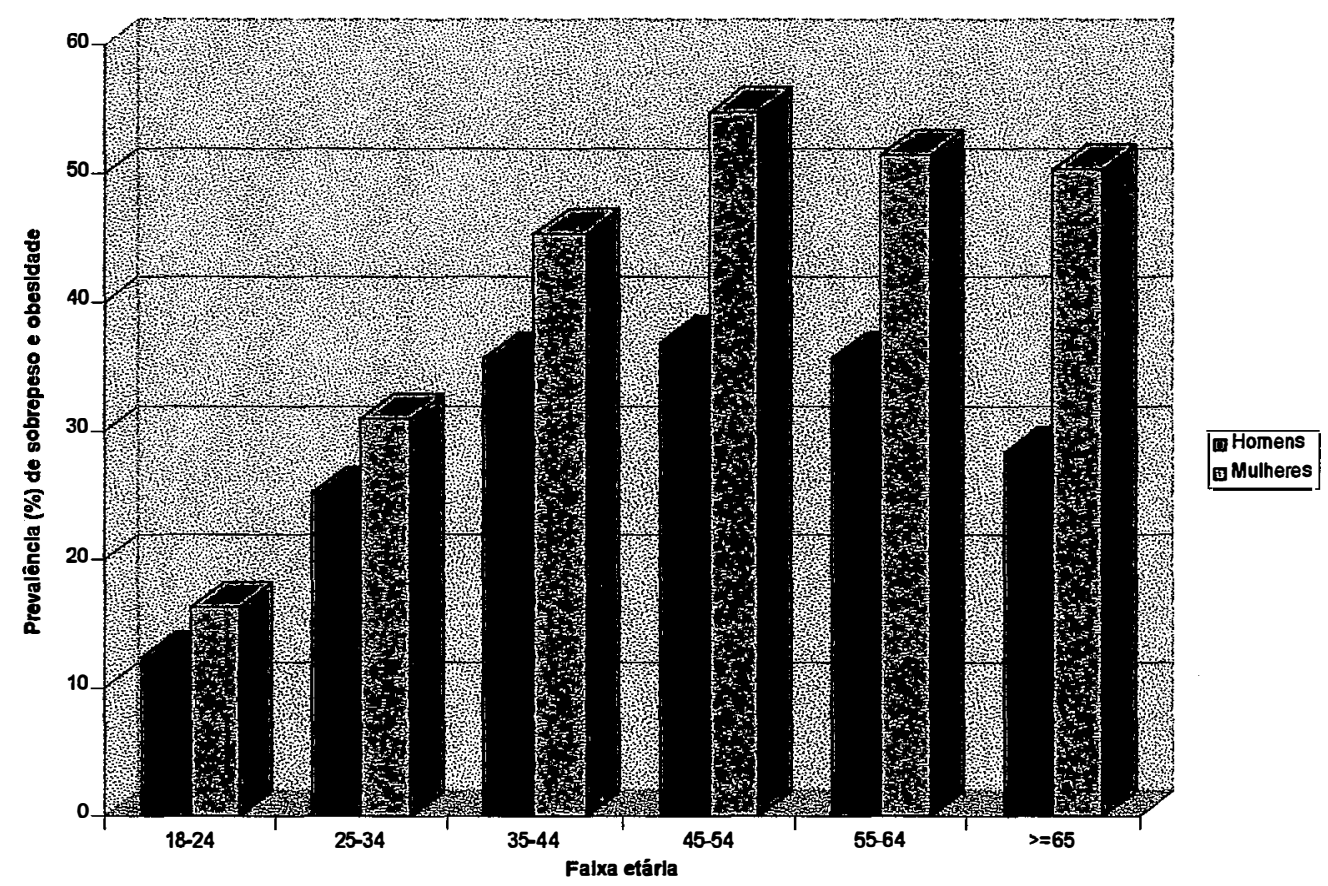

Figura 3 - Prevalência (\%) de sobrepeso e obesidade segundo sexo e idade, Brasil, 1989.

O excesso de peso tem graves consequências à saúde das pessoas uma vez que o sobrepeso e a obesidade aumentam a possibilidade de ocorrência e o agravamento de várias doenças. Entre elas destacam-se a hipertensão, a diabetes e as doenças cardiovasculares.

De acordo com a Figura 4 a prevalência de baixo peso não apresentou diferença significativa entre os sexos. Aproximadamente 6,1 milhões de homens (15,4\%) e 6,9 milhões de mulheres (16,5\%) têm baixo peso, atingindo cerca de 13 milhões de adultos brasileiros . 
A idade é uma importante variável explicativa para prevalência de baixo peso. Aproximadamente um quarto da população jovem, na faixa etária 18-24 anos, possuem baixo peso. Os jovens sofrem profundas transformações pois assumem maior responsabilidade na sociedade, que são associadas a maior stress. Como exemplo, podese citar a maternidade, a entrada no mercado de trabalho e a constituição de família. Entretanto, os aspectos biológicos que afetam os jovens não podem ser desconsiderados. É certo que a prevalência de baixo peso na parcela dos jovens é um assunto complexo, existindo poucos estudos que permitam maiores comentários.

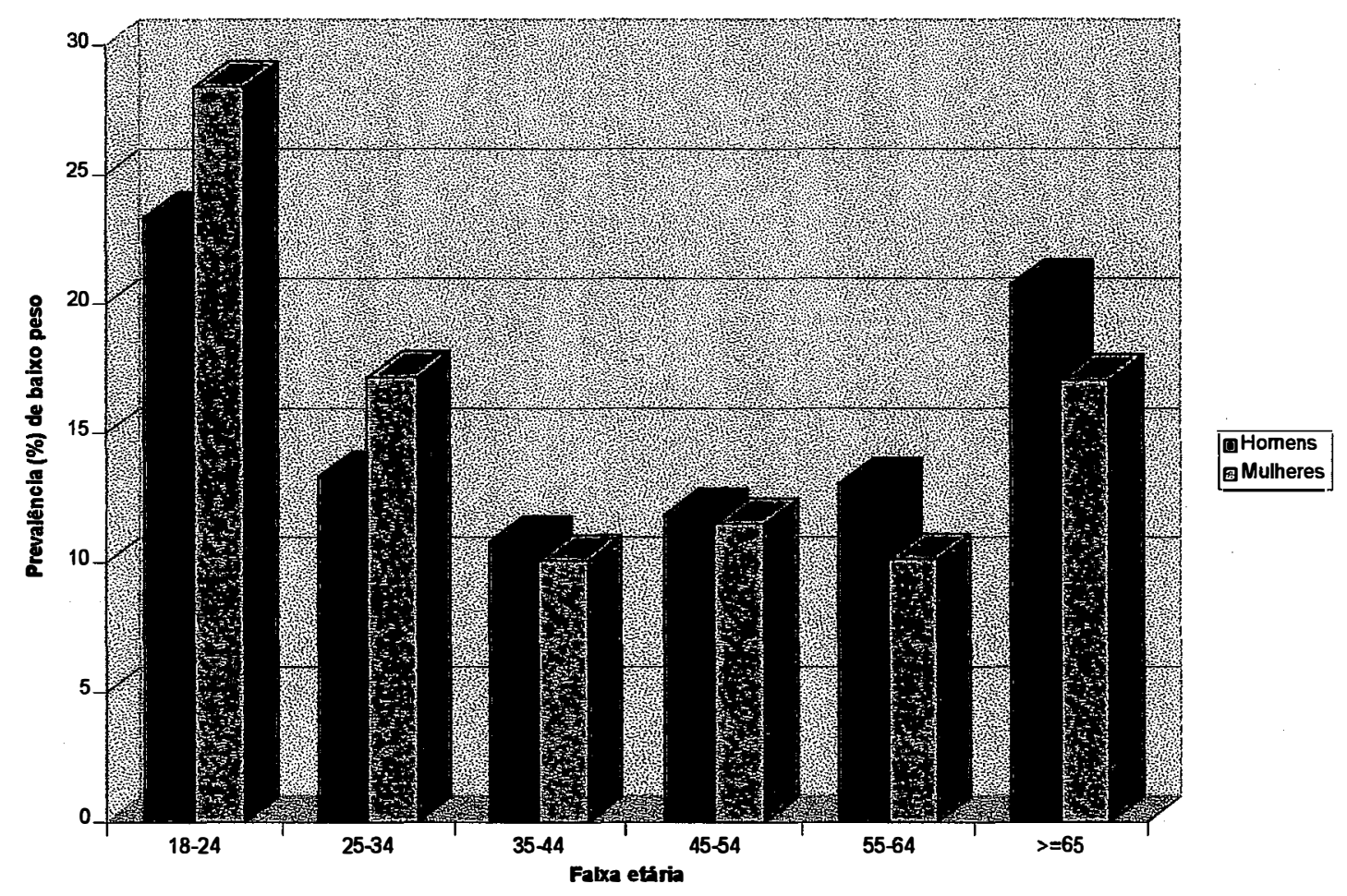

Figura 4 - Prevalência (\%) de baixo peso segundo sexo e idade. Brasil, 1989.

Verifica-se que a prevalência de baixo peso diminui com a idade e tende a assumir os menores valores para a faixa etária dos 35 aos 44 anos. As freqüências de baixo peso voltam a subir para a população com 45 ou mais, indicando um salto 
importante a partir dos 65 anos para os dois sexos. De acordo com INAN/IBGE/IPEA (1989) os fatores que provavelmente contribuem para a deterioração do estado de nutrição da população idosa atuam de forma sinérgica podendo ser agrupados em:

a) maior vulnerabilidade biológica;

b) isolamento, solidão e perda do status social;

c) pobreza.

Quando a prevalência de baixo peso é analisada de acordo com a região onde reside o indivíduo, observa-se que a região Nordeste apresenta taxa de $21,74 \%$ dos adultos com baixo peso (Figura 5). A região Sul apresenta a menor freqüência tendo aproximadamente $10 \%$ de sua população maior de 18 anos afetada por problemas de baixo peso. Se este problema for analisado em termos absolutos, constata-se que é na Região Sudeste que o problema se agrava pois cerca de 6 milhões de pessoas são afetadas (14,7\% da população). 


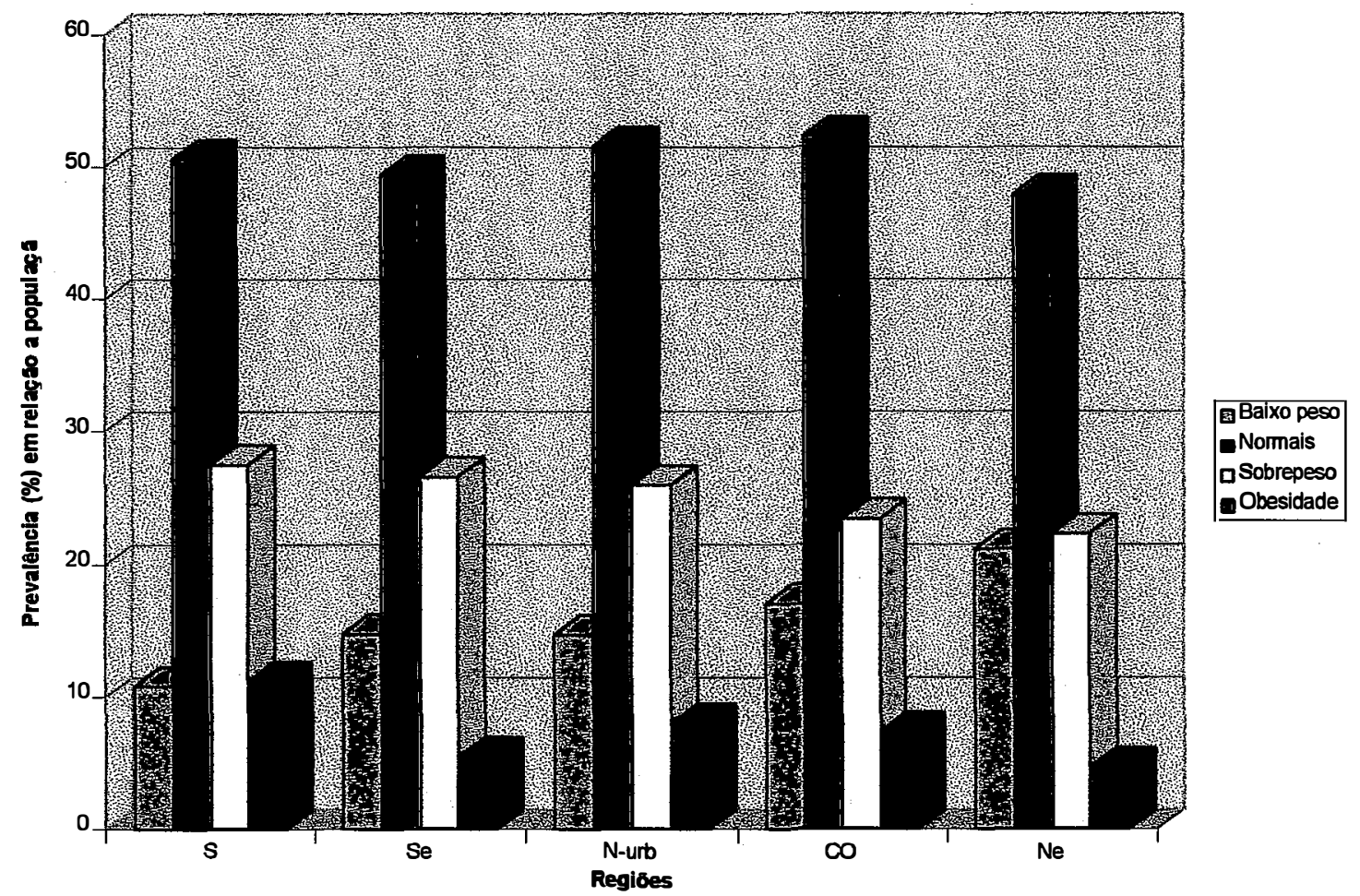

Figura 5 - Prevalência (\%) de baixo peso, obesidade, padrão normal, sobrepeso e obesidade, segundo regiões, Brasil, 1989.

O problema de excesso de peso apresenta-se em todas as regiões brasileiras. Em termos relativos a região Sul apresenta maior participação percentual nos problemas de obesidade e sobrepeso. Nesta região $34 \%$ dos homens e $45 \%$ das mulheres apresentam algum grau de excesso de peso, totalizando cerca de 5 milhões de adultos. As regiões Sudeste, Norte, Centro-Oeste e Nordeste possuem, respectivamente, $36 \%, 34 \%, 31 \%$ e $24 \%$ de seus adultos com problemas relacionados ao excesso de peso.

Ao analisar a prevalência de baixo peso em relação a renda, o INAN/IBGE/IPEA (1989) cita que para os jovens, esta variável, parece não atuar de forma significativa. A diferença nos grupos de renda se acentua com a idade. 0 grupo de idosos de menor renda 
apresenta mais do que o dobro da prevalência de baixo peso quando comparado com aqueles cuja renda mensal excede dois salários mínimos per capita.

Nos casos de obesidade as mulheres residentes na zona rural e pertencentes a famílias com renda superior a dois salários mínimos per capita são as mais afetadas (Tabela 3). Somente para a faixa de renda menor do que 0,5 salário-mínimo per capita a prevalência de obesidade é maior na zona urbana do que na rural.

Tabela 3 - Prevalência (\%) de obesidade segundo sexo, situação de domicílio e renda domiciliar mensal per capita no Brasil, 1989.

\begin{tabular}{llll}
\hline Situação & Renda (salário-mínimo) & \% Homens & \% Mulheres \\
\hline \multirow{3}{*}{ Rural } & $<0,5$ & 0,8 & 6,8 \\
& entre 0,5 e 2,0 & 2,8 & 16,5 \\
& $>2,0$ & 6,6 & 18,5 \\
& & & \\
\multirow{4}{*}{ Urbano } & entre 0,5 e 2,0 & 3,3 & 15,2 \\
& $>2,0$ & 5,8 & 13,6 \\
\hline
\end{tabular}

Fonte: INAN/IBGE/IPEA (1989).

\subsection{Modelos econométricos}

Neste item serão apresentados os modelos econométricos adotados neste estudo. O primeiro modelo refere-se à estimação das perdas de rendimento provocadas por condições adversas de saúde e o segundo detalha a estimação de uma equação para captar a relação entre saúde e condições de saneamento básico e outros fatores que afetam a produção da saúde, como, por exemplo, a educação e a idade. É importante ressaltar que a escolha das variáveis especificadas nestes modelos foi fortemente influenciada pelos trabalhos realizados por Kassouf (1993 e 1996). 


\subsubsection{O modelo econométrico adotado no estudo: procedimentos e descrição das variáveis}

Conforme foi ressaltado anteriormente, este modelo econométrico adotará os procedimentos de estimação apresentados por Harrold S. Luft. Primeiramente são obtidas duas amostras distintas e a partir daí, estimadas duas equações. A primeira equação engloba toda a amostra contendo indivíduos saudáveis (IMC $\geq 20$ ), de acordo com o Índice de Massa Corpórea (IMC) disponível na $\mathrm{PNSN}^{16}$. A segunda equação inclui apenas os indivíduos com condições de saúde inadequada ( $\mathrm{IMC}<20$ ), seguindo os mesmos critérios adotados na primeira equação. É importante ressaltar que os indivíduos na amostra serão ponderados pelo fator de expansão da amostra.

H. S Luft propõe o cálculo da diferença total que é definida como sendo a diferença entre o valor médio da variável dependente obtido na amostra de indivíduos saudáveis e o valor médio obtido na amostra de indivíduos doentes. Este valor não exclui os efeitos provocados por outras variáveis não relacionadas às condições de saúde. Portanto, este cálculo será desconsiderado neste estudo. Para anular o erro presente neste cálculo será realizado um novo procedimento para a obtenção da diferença ajustada. Esta diferença é igual ao valor médio da variável dependente obtido para a população de saudáveis menos a estimativa obtida para a população doente computada na regressão para pessoas saudáveis (coeficientes) e com as características da população doente (média).

A Tabela 4, a seguir, apresenta as variáveis a serem utilizadas neste modelo. É importante ressaltar que a maioria das variáveis propostas por Luft (1974) está presente nessa tabela. Isto comprova a qualidade das informações presentes na PNSN.

\footnotetext{
${ }^{16}$ No próximo ítem o processo de seleção da amostra será analisado detalhadamente.
} 
Tabela 4 - Descrição das variáveis explicativas e dependentes no modelo.

\begin{tabular}{ll}
\hline \multicolumn{1}{c}{ Variáveis } & \multicolumn{1}{c}{ Definição } \\
\hline Variáveis Explicativas & \\
Idade & Idade do indivíduo em anos \\
Idade2 & Idade do indivíduo elevada ao quadrado \\
Educação & Idade de anos de escolaridade \\
Idade x educação & Renda não salarial per capita em dólares \\
Rendanãosalarial & Número de filhos de até 2 anos de idade \\
Filhos2 & Número de filhos de 3 a 5 anos de idade \\
Filhos3-5 & Número de filhos de 6 a 12 anos de idade \\
Filhos6-12 & Número de filhos com 13 anos ou mais \\
Filho>=13 & Número de fillhas com 13 anos ou mais \\
Filha>=13 & $=1$ se o indivíduo reside na região Norte \\
Norte & $=1$ se o indivíduo reside na região Centro-Oeste \\
Centro-Oeste & $=1$ se o indivíduo reside na região Sudeste \\
Sudeste & $=1$ se o indivíduo reside na região Sul \\
Sul & $=1$ se o indivíduo reside no setor urbano \\
Urbano & $=1$ se o indivíduo é da raça parda \\
Pardo & $=1$ se o indivíduo e da raça branca ou asiático \\
Bramarel & $=1$ se o indivíduo é chefe na família \\
Chefe & $=1$ se o indivíduo é cônjuge na família \\
Cônjuge & $=1$ se o indivíduo é filho na família \\
Filho & $=1$ se o indivíduo é pertencente a outro parentesco \\
Outros & \\
Variáveis & \\
Dependentes & \\
Trabalha & \\
Logrhr & zero \\
& \\
&
\end{tabular}

As variáveis explicativas procuram captar um amplo conjunto de informações, tais como características individuais dos indivíduos, localização geográfica, cor e condição na família. A utilização das variáveis dummy de localização geográfica permitirá a análise dos possíveis desequilíbrios regionais na área de saúde.

As variáveis dependentes incluem a participação do indivíduo na força de trabalho e o rendimento obtido. A variável Trabalha inclui todos os indivíduos com 
rendimento positivo ${ }^{17}$. A variável Logrhr é o logaritmo do rendimento obtido em uma hora de trabalho.

A Tabela 5 mostra um resumo das etapas a serem seguidas para se obter o montante total de perda de rendimento (item 9) o qual é definido como sendo a soma do rendimento perdido devido a não participação na força de trabalho (item 5) e o rendimento perdido pelas pessoas que participam da força de trabalho mas que recebem menos do que elas poderiam receber se estivessem bem (com saúde) durante um determinado ano base (item 8). Para captar as perdas de rendimento dos indivíduos com condições de saúde adversas o total da força de trabalho (item 6) é multiplicado pela estimativa das perdas de rendimento para o ano base. Para se obter as perdas de rendimento das pessoas doentes, devido a não participação no mercado de trabalho, o primeiro passo será encontrar o numero de adultos doentes (item 1). Posteriormente, será utilizada a diferença ajustada para a variável Trabalha, que indica a probabilidade de um indivíduo doente que não participa do mercado de trabalho participar caso seja saudável, ou seja, utilizam-se os coeficientes de um modelo próbite (participa/não participa) para a amostra de saudáveis com as médias da amostra de doentes para calcular a diferença ajustada (item 2). Ao se multiplicar o item 1 pela item 2 serão obtidas as perdas de trabalhadores. Esta perda de mão-de-obra (item 3) será multiplicada pelo rendimento por hora dos doentes (linha 4) para se encontrar as perdas de rendimento provocadas pela condições inadequadas de saúde (linha 5)

\footnotetext{
${ }^{17}$ A variável Trabalha possui a limitação de não incluir os indivíduos que trabalham e não recebem qualquer forma de rendimento.
} 
Tabela 5 - Descrição dos dados e cálculos a serem adotados na estimativa das perdas de rendimento total.

\begin{tabular}{ll}
\hline \multicolumn{1}{c}{ Dados } & \multicolumn{1}{c}{ Cálculo } \\
\hline 1- População de adultos doentes em mil pessoas & \\
Perdas para as pessoas que estão doentes e continuam fora & \\
do mercado de trabalho & \\
2- Diferença Ajustada / Trabalha & (linha 1 multiplicada pela linha 2) \\
3- Perdas de Pessoas & \\
4- Estimativas de Rendimento para os doentes & (linha 3 multiplicada pela linha 4) \\
5- Perdas de rendimento em dólares (doentes) \\
Perdas das Pessoas que Participam da Força de Trabalho \\
6- Força de Trabalho em mil pessoas \\
7- Diferenças Ajustada /Logrhr \\
8- Perdas em dólares & (linha 6 multiplicada pela linha 7) \\
9- Perda total & (linha 5 mais linha 8) \\
\hline
\end{tabular}

\subsubsection{A equação de saúde: descrição das variáveis}

Conforme citado anteriormente, serão estimadas quatro equações de saúde, uma para as mulheres normais e de baixo peso (IMC $\leq 25)$, a segunda para mulheres normais, com sobrepeso e obesidade ( $\mathrm{MC} \geq 20$ ), a terceira para os homens normais e de baixo peso (IMC $\leq 25)$ e a última para os homens normais, com sobrepeso e obesidade (IMC 220). Nessas equações, a variável dependente será o Índice de Massa Corporal (IMC). Este procedimento foi adotado para evitar problemas de interpretação oriundos da variável Fuma. Caso fosse estimada apenas duas equações, uma para os saudáveis e outra para os doentes, o sinal da variável Fuma poderia levar a erros de interpretação do sinal dos coeficientes. É certo que o vício de fumar provoca uma diminuição do peso nos indivíduos. Então, se um indivíduo estiver com sobrepeso e começar a fumar; é possível 
que o seu IMC diminua, podendo inclusive torna-lo normal pelo critério do IMC. Para evitar este erro, adotou-se o critério exposto anteriormente.

As variáveis explicativas, adotadas neste modelo, procuram identificar importantes aspectos que afetam a saúde dos indivíduos, tais como a idade, educação, raça e localização geográfica. Entretanto, o objetivo principal será discutir a importância da infra-estrutura sobre as condições de saúde da população brasileira. As variáveis Abastecimento, Esgoto, Lixo e Luz são fundamentais para a realização deste objetivo.

As variáveis utilizadas na estimação das equações de saúde são descritas na Tabela 6. 
Tabela 6 - Descrição das variáveis utilizadas no modelo de Becker adaptado

\begin{tabular}{ll}
\hline \multicolumn{1}{c}{ Variável } & \\
\hline Endógena & Índice de massa Corporal $\left(\mathrm{p} / \mathrm{h}^{2}\right)$ \\
Saúde & \\
Exógenas & Número de anos de escolaridade \\
Educação & Idade do indivíduo em anos \\
Idade & Idade do indivíduo elevada ao quadrado \\
Idade2 & $=1$ se o indivíduo e da raça branca ou asiático \\
Bramarel & $=1$ se o indivíduo é da raça parda \\
Pardo & $=1$ se o indivíduo reside na região Norte \\
Norte & $=1$ se o indivíduo reside na região Centro-Oeste \\
Centro-Oeste & $=1$ se o indivíduo reside na região Sudeste \\
Sudeste & $=1$ se o indivíduo reside na região Sul \\
Sul & $=1$ se o indivíduo reside no setor urbano \\
Urbano & Estimativa da renda não salarial mensal per capita \\
Rendanãosalarial & Número de vezes que o indivíduo fuma por dia \\
Fuma & $=1$ se existe rede geral com canalização na \\
Abastecimentoágua & residência \\
Esgoto & $=1$ se existe sistema de esgoto na residência \\
Lixo & $=1$ se o lixo é coletado na residência \\
Luz & $=1$ se há eletricidade na residência \\
\hline
\end{tabular}

Considera-se que a educação provoca um efeito eficiência na produção da saúde, ou seja, quanto maior o grau de escolaridade de uma pessoa, mais conhecimento poderá ser empregado para se tomar atitudes que possibilitem a melhoria da condição de saúde.

As variáveis Idade e Idade2 são utilizadas para verificar o efeito do tempo sobre as condições de saúde. 
As variáveis Bramarel e Pardo procuram captar possíveis diferenças nas condições de saúde entre raças. Vale lembrar que elas poderão captar algum tipo de discriminação racial, no sentido que os brancos são privilegiados quanto ao acesso aos serviços de saúde.

As variáveis regionais possibilitarão captar as desigualdades regionais existentes no Brasil. No que tange aos setores urbano e rural, observa-se que os problemas advindos da poluição e superpopulação, podem trazer dúvidas no resultado da equação, mesmo sabendo-se que o setor urbano é mais desenvolvido do que o setor rural. Salienta-se que Kassouf (1996) encontrou um coeficiente negativo para o setor urbano nas demandas de saúde de crianças.

A variável Rendanãosalarial deverá propiciar um efeito positivo na saúde dos indivíduos. A renda maior permite maior alocação de recursos em saúde e cuidados médicos.

A variável Fuma é utilizada para captar o efeito do tabagismo sobre as condições de saúde. As informações sobre saúde pública indicam que o vício de fumar provoca sérios danos à saúde, tais como o câncer pulmonar. Portanto, espera-se que exista uma relação negativa entre a variável Fuma e a variável Saúde.

As variáveis relacionadas à infra-estrutura do domicílio refletem condições sanitárias adequadas para a obtenção de melhores condições de saúde. Diversos estudos indicam o efeito positivo da presença de infra-estrutura no domicílio (saneamento básico) sobre a saúde das crianças. Entres os principais estudos estão os realizados por Merrick (1985), Thomas \& Strauss (1992) e Kassouf (1995).

A variável Abastecimentoágua procura identificar se existe rede geral com canalização na residência e a variável Esgoto capta a existência de esgoto sanitário. 
Espera-se que haja um relacionamento positivo entre as condições de saúde e a presença de esgoto e rede geral de canalização na residência, pois o aparecimento de algumas doenças, como, por exemplo, o cólera e esquistossomose, está intimamente ligado à inexistência de esgotos sanitários.

Espera-se um efeito positivo do processo de coleta de lixo sobre a saúde dos indivíduos, pois é notório que a inexistência deste serviço pode provocar sérios danos à saúde dos indivíduos devido à deterioração de produtos, presença de ratos e contaminação de córregos e rios.

A última variável utilizada na equação de saúde procura captar o efeito da existência de energia elétrica sobre as condições de saúde. É válido salientar que a energia elétrica possui um efeito positivo sobre as condições de saúde tendo em vista que quanto melhores as condições de salubridade da residência, melhor será a produção da saúde, pois a presença de energia elétrica permite a utilização de equipamentos que possibilitam melhores condições de saúde. Como exemplo, pode-se citar a utilização de geladeiras que possibilitam melhores condições de conservação dos alimentos.

\subsection{A seleção da amostra}

Neste estudo optou-se por utilizar apenas o ponto de corte inferior para delimitar a amostra de saudáveis e doentes. Sendo assim, a população de doentes, expandida pelo fator de ponderação elaborado pelo IBGE será composta pelos indivíduos com IMC menor do que 20 (baixo peso preocupante). Já, a população de indivíduos saudáveis incluirá as pessoas com IMC acima de 20. Tal procedimento se deve ao fato de que a inclusão dos indivíduos com obesidade extrema (IMC >30) como doentes carece de maior respaldo teórico e de estudos em nível internacional. 
A Tabela 7, a seguir, apresenta a amostra e a população de homens saudáveis e doentes, assim como a porcentagem de doentes e saudáveis em cada região e setor no Brasil. Observa-se que, a maior percentagem de homens saudáveis na região Sul e a menor na região Nordeste. O setor urbano apresenta maior porcentagem de homens saudáveis comparativamente ao setor rural.

No que se refere à população de homens doentes verifica-se que a maior porcentagem está na região Nordeste e no setor Rural.

Tabela 7 - População de homens saudáveis, população de homens doentes e variação percentual por regiões e setores do Brasil (exclusive a população rural da Região Norte), de 1989.

\begin{tabular}{lrrrrrr}
\hline $\begin{array}{l}\text { Regiões/ } \\
\text { Setores }\end{array}$ & \multicolumn{3}{c}{ Saudáveis } & \multicolumn{3}{c}{ Doentes } \\
\hline \multicolumn{1}{l}{ Pudeste } & 14451490 & 2951 & 82,5 & 3067439 & 713 & 17,5 \\
Sul & 5335475 & 3106 & 88,2 & 711981 & 431 & 11,8 \\
Centro-Oeste & 2141330 & 2656 & 80,9 & 505844 & 645 & 19,1 \\
Nordeste & 7331023 & 2721 & 78,8 & 1974627 & 742 & 21,2 \\
Norte* & 938480 & 1625 & 84,6 & 170445 & 297 & 15,4 \\
Urbano & 22933263 & 7403 & 83,8 & 4414088 & 1373 & 16,2 \\
Rural & 7264535 & 5656 & 78,3 & 2016248 & 1455 & 21,7 \\
Brasil & 30197798 & 13059 & 82,4 & 6430336 & 2828 & 17,6 \\
\hline
\end{tabular}

* Inclui somente o Norte Urbano.

A Tabela 8, a seguir, apresenta a população feminina de saudáveis e doentes para as regiões e setores do Brasil, além da variação percentual. Observa-se que para as mulheres saudáveis, a região Sul também apresenta a maior percentagem, enquanto que a região Nordeste apresenta a maior porcentagem de mulheres doentes. 
Tabela 8 - População de mulheres saudáveis, população de mulheres doentes e variação percentual por Região e Setores do Brasil (exclusive a população rural da Região Norte), de 1989.

\begin{tabular}{lrrrrrr}
\hline $\begin{array}{l}\text { Regiões/ } \\
\text { Setores }\end{array}$ & \multicolumn{3}{c}{ Saudáveis } & \multicolumn{3}{c}{ Doentes } \\
\hline & População & Amostra & $\%$ & População & Amostra & $\%$ \\
\hline Sudeste & 15911368 & 3098 & 84,7 & 2882431 & 603 & 15,3 \\
Sul & 5659132 & 3188 & 87,5 & 806103 & 468 & 12,5 \\
Centro-Oeste & 2216731 & 2587 & 80,2 & 546893 & 647 & 19,8 \\
Nordeste & 8110084 & 2988 & 77,0 & 2424132 & 912 & 23,0 \\
Norte & 994157 & 1736 & 82,7 & 207230 & 351 & 17,3 \\
Urbano & 26084652 & 8410 & 84,1 & 4942187 & 1672 & 15,9 \\
Rural & 6806820 & 5187 & 78,0 & 1924602 & 1309 & 22,0 \\
Brasil & 32891472 & 13597 & 82,7 & 6866789 & 2390 & 17,3 \\
\hline
\end{tabular}

Nota-se que o percentual de mulheres saudáveis é maior no setor Urbano. Tal fato pode ser explicado pelo menor acesso às melhores condições de saneamento básico e assistência médica no setor rural do Brasil.

Comparando-se as Tabelas 7 e 8, observa-se que na região Sudeste e no setor Urbano, a proporção de homens doentes é maior do que a de mulheres doentes. Entretanto, nas demais regiões e no setor Rural observa-se o contrário.

Outro indicador disponível na PNSN é o sintoma de doença, como os problemas respiratórios, dor de cabeça, diarréia e outros. A desvantagem na utilização deste indicador consiste nos possíveis erros ocasionados por respostas subjetivas por parte dos entrevistados. Devido a estas desvantagens, neste estudo o indicador do estado de saúde será o IMC.

As médias de participação para homens e mulheres permitem alguns importantes comentários. 
Na tabela 9, descrita a seguir, pode-se verificar que a idade média dos doentes, que participam do mercado de trabalho, nas regiões Centro-Oeste, Norte e Nordeste é inferior à encontrada nas regiões Sudeste e Sul. Quando a comparação é feita para os setores observa-se que os trabalhadores doentes do setor urbano são mais jovens comparativamente aos trabalhadores do setor rural. 


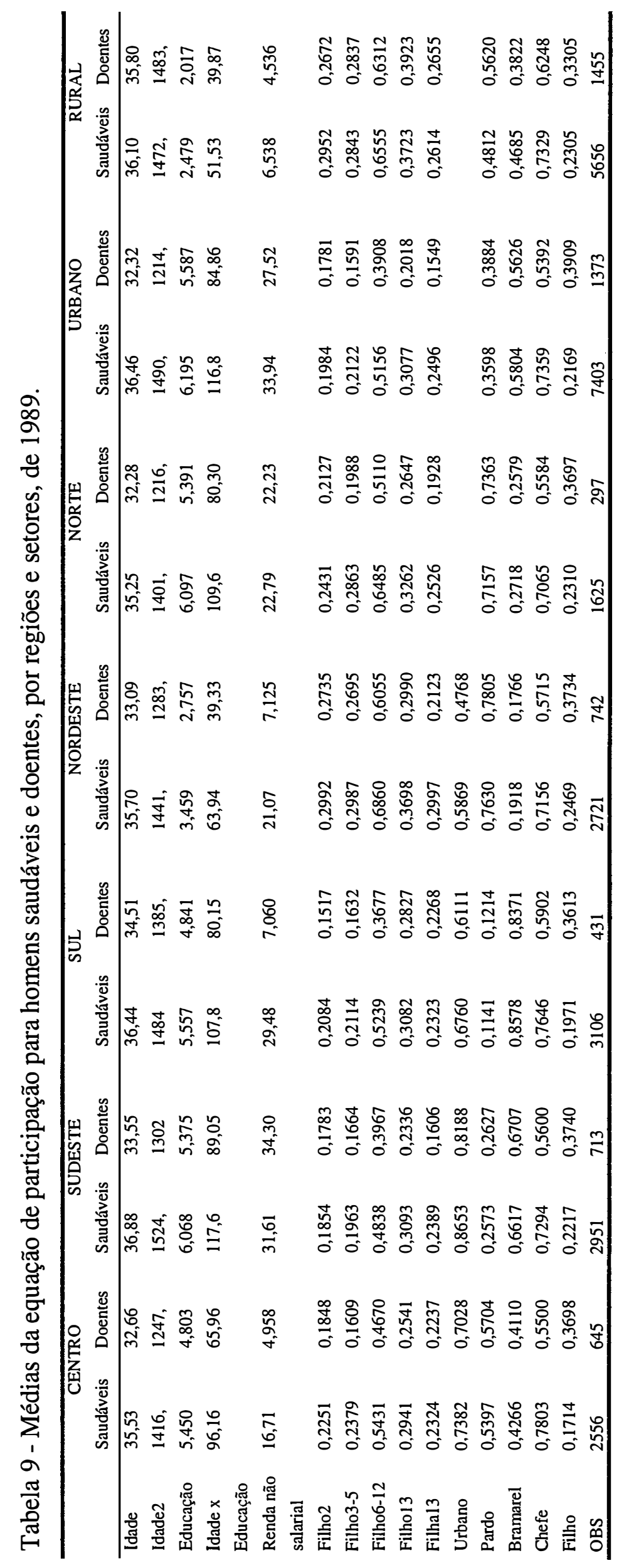


Ao se analisar a variável educação, constata-se que os anos de estudo dos trabalhadores saudáveis, são em todos as regiões e setores, superiores comparativamente aos indivíduos doentes. Este fato é esperado tendo em vista que quanto maior o grau de escolaridade melhor tende a ser a sua saúde.

Outra importante constatação é de que a renda não salarial dos trabalhadores saudáveis é muito superior a renda dos doentes.

A Tabela 10 apresenta as médias de participação no mercado de trabalho para as mulheres. Pode-se dizer que, ao se analisar a variável idade, os doentes mais jovens encontram-se nas regiões Centro-Oeste e Sudeste. O setor rural apresenta as mulheres doentes mais jovens comparativamente ao setor rural. As médias da variável idade apresentam comportamento diferente em relação aos homens, acontecendo o mesmo para a variável educação. 


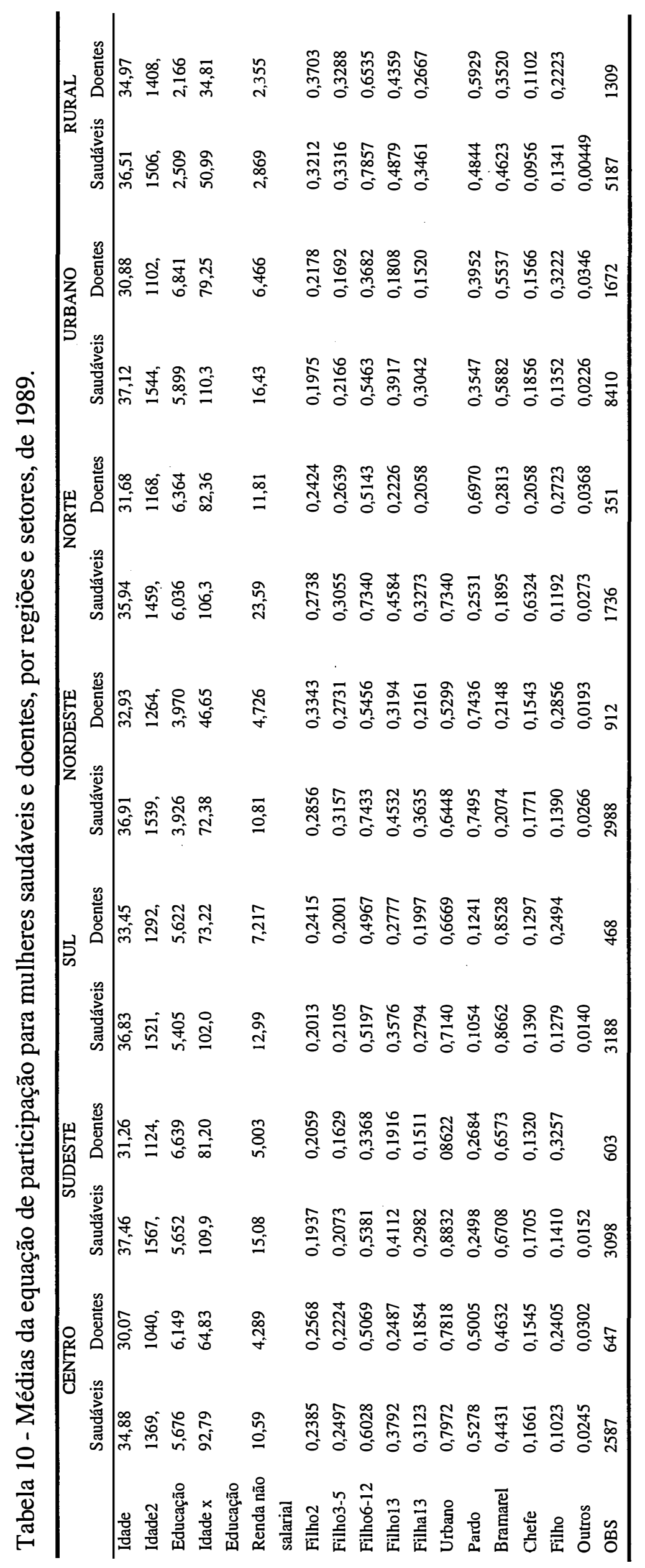


A variável renda não salarial permite constatar que as mulheres possuem em média menor rendimento através de, por exemplo, aluguel se comparado com os homens.

As médias de rendimento para homens e mulheres encontram-se em anexo nas tabelas A.15 e A.16. 


\section{ESTIMAÇÃO}

\subsection{O procedimento de Heckman na obtenção da estimativa do salário}

Conforme ressaltado no capitulo anterior, serão estimadas equações de participação no mercado de trabalho e de determinação de salários para o cálculo das perdas de rendimento. Numa amostra de adultos o número do indivíduos que não trabalham geralmente é significativo, podendo provocar um viés de seletividade amostral ao se estimar as equações de rendimento, por mínimo quadrados, apenas para os indivíduos que participam do mercado de trabalho. Visando solucionar este problema, será utilizado o procedimento de Heckman.

Kassouf (1994) apresentou as vantagens econométricas na utilização do procedimento de Heckman na estimativa salarial, além de derivar o custo de oportunidade do tempo através da estimação da equação de participação da força de trabalho e taxa salarial, comparando os resultados com o método tradicional de estimação. Os resultados deste estudo indicaram uma tendenciosidade positiva (em valor absoluto) nas estimativas dos parâmetros da amostra masculina e uma tendenciosidade negativa (em valor absoluto) para trabalhadores do sexo feminino. 


\subsection{O modelo econométrico de Heckman ${ }^{18}$ :}

O salário pode ser usada para representar o custo de oportunidade do tempo. Normalmente nem todos os indivíduos estão empregados no mercado de trabalho e a estimativa do salário pode ser calculada.

A estimativa da equação de salário utilizando-se mínimos quadrados ordinários poderá causar viés devido a seletividade da amostra onde apenas os indivíduos que participam da amostra entram no cálculo. Para analisar este problema considere que $L^{*}$ seja a variável que representa a participação do indivíduo na força de trabalho, então pode se escrever:

$$
L_{i}^{*}=\gamma^{\prime} Z_{i}+u_{i}
$$

onde $Z$ é o vetor das variáveis que determina a participação do indivíduo $i$ no mercado de trabalho.

Sabe-se que $L^{*}$ não é observado na prática, mas $L$ pode ser observado, tal que,

$$
\begin{aligned}
& L_{i}=1 \quad \text { se } L_{i}^{*}>0 ; \\
& L_{i}=0 \quad \text { se } L_{i}^{*} \leq 0 ;
\end{aligned}
$$

Representando $W$ como o salário;

$$
W_{i}=\beta \cdot R_{i}+v_{i}
$$

\footnotetext{
${ }^{18}$ O modelo econométrico de Heckman está detalhadamente comentado e descrito em Kassouf (1994).
} 
onde $R_{i}$ é o vetor das variáveis que determina os salários.

Pode-se observar $W$ apenas quando $L^{*}$ é maior do que zero. Pressupondo-se que $u_{i}$ e $v_{i}$ tệm distribuição normal bivariada com média zero, desvio padrão $\sigma_{u} \mathrm{e} \sigma_{v}$, e correlação $\rho$, então

$$
\begin{aligned}
E\left(W_{i} \mid W_{i} \text { é observada }\right) & =E\left(W_{i} \mid L_{i}^{*}>0\right)=E\left(W_{i} \mid u_{i}>-\gamma^{\prime} Z_{i}\right) \\
& =\beta \cdot R_{i}+E\left(v_{i} \mid u_{i}>-\gamma^{\prime} Z_{i}\right) \\
& =\beta \cdot R_{i}+\rho \sigma_{\nu} \lambda_{l}\left(\alpha_{u}\right)
\end{aligned}
$$

onde,

$$
\lambda_{i}\left(\alpha_{u}\right)=\frac{\phi\left(\frac{\gamma \cdot Z_{i}}{\sigma_{u}}\right)}{\Phi\left(\frac{\gamma^{\prime} Z_{i}}{\sigma_{u}}\right)}
$$

e $\phi$ e $\Phi$ são respectivamente, a função de densidade de probabilidade e a função de distribuição acumulada para a distribuição normal. A função $\lambda_{l}\left(\alpha_{u}\right)$ é chamada de inverso da razão de Mill.

Tomando-se a equação (16), a regressão pode ser escrita como

$$
W_{i} \mid L_{i}^{*}>0=\beta \cdot R_{i}+\beta_{\lambda} \lambda_{i}\left(\alpha_{u}\right)+\varepsilon_{i}
$$

Se a equação da taxa salarial for estimada pelo método de mínimo quadrados ordinários, incluindo apenas os indivíduos que estão trabalhando, as estimativas de $\beta$ serão inconsistentes devido a não inclusão da variável $\lambda$. 
Não obstante, a estimativa da taxa salarial pelo método dos mínimos quadrados, em função de $R$ e $\lambda$ mesmo que, utilizando-se apenas os indivíduos que participam do mercado de trabalho, produzirá estimativas consistentes de $\beta$.

De acordo com Heckman $\left(1974^{19} \& 1980^{20}\right)$, citado por Kassouf (1994), o procedimento de estimação deve seguir os seguintes passos:

1) estimar a equação de participação no mercado de trabalho, fazendo-se a regressão de $\mathrm{L}$ em função de $Z$ pelo método de máxima verossimilhança, utilizando-se $o$ modelo Próbite, onde $\mathrm{L}$ assumirá valor 0 se o indivíduo não participar do mercado de trabalho ou 1 se o mesmo estiver recebendo rendimento. Com a estimativa de $\gamma$, resultante deste modelo, é possível calcular a estimativa de $\lambda$. Tendo a estimativa de $\lambda$, pode-se fazer a regressão de $W$ em função de $\mathrm{R}$ e $\hat{\lambda}$, utilizando-se mínimos quadrados ordinários e obter a estimativa consistente de $\beta$.

\subsection{A aplicação do modelo de Heckman na obtenção das perdas de rendimento}

Utilizando-se os mesmos procedimentos citados no item 5.2.1, primeiramente será estimada a equação de participação no mercado de trabalho através do modelo Próbite. A variável Trabalha assumirá valor um se o indivíduo tiver salário positivo e valor zero, caso contrário. Com base nos coeficientes estimados no modelo Próbite será estimada a variável LAMBDA que será utilizada na equação de rendimentos. Desta forma, serão corrigidos os problemas gerados pela não inclusão das pessoas adultas que não recebem salário.

\footnotetext{
${ }^{19}$ Heckman, J. Shadow prices, market wages, and labor supply. Econométrica, v.1, 679-694 p. 1974.

${ }^{20}$ Heckman, J. Sample selection bias as a specification error. In Smith, J.P, Female Labor Suply:

Theory and Estimation. Princeton University Press, v.1, 1980.
} 


\section{RESULTADOS}

Neste capítulo apresentam-se os resultados das estimativas das perdas de rendimento e das equações de saúde.

\subsection{As estimativas das perdas de rendimento}

Antes de iniciar os comentários sobre as estimativas das perdas de rendimento deve-se ressaltar que o importante é a comparação relativa das referidas perdas entre as regiões e os setores. Esta afirmação surge do fato de que os valores das perdas de rendimento em termos absolutos são apenas estimativas que, apesar de estarem metodologicamente corretos possuem limitações.

Outro ponto importante a ser destacado é o fato de as estimativas das perdas de rendimento referentes à população masculina apresentarem um melhor ajustamento. Os valores das estimativas das perdas de rendimento para os homens foram positivos para todos os tipos de perdas e para todas as regiões e setores.

A Tabela 11 apresenta a os coeficientes da equação de participação para os homens saudáveis e doentes, conforme as regiões e setores. 


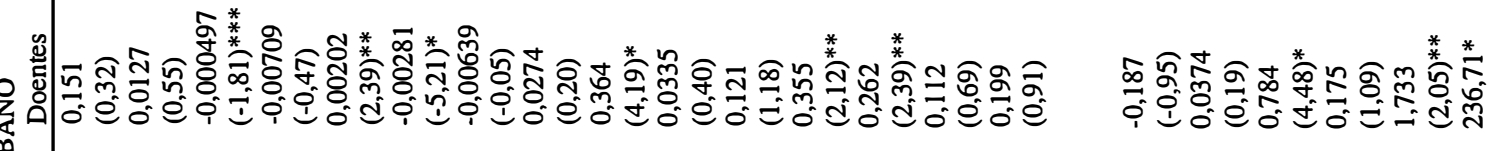

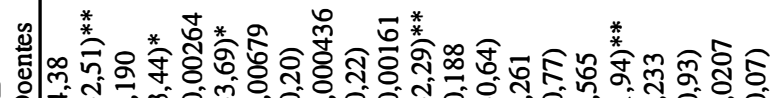

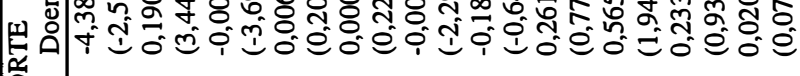

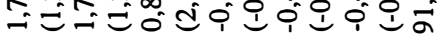

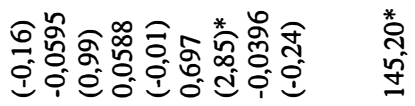

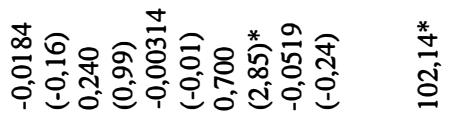

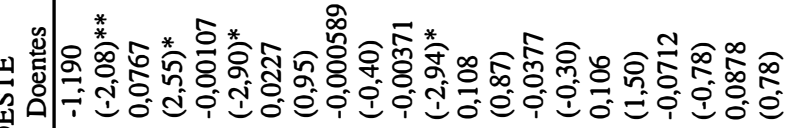

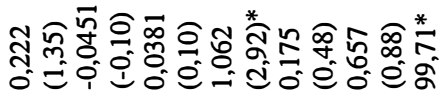

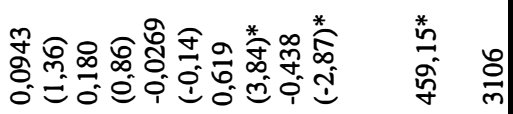

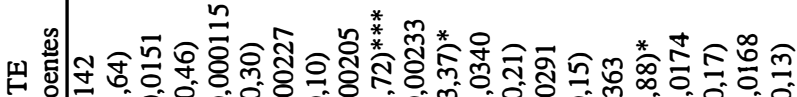

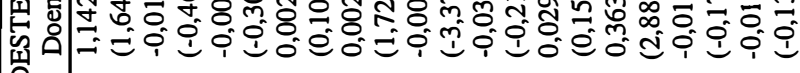

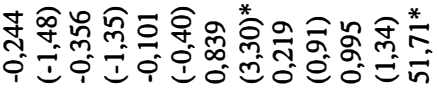

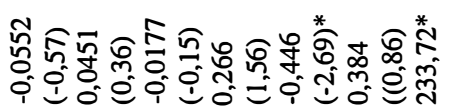

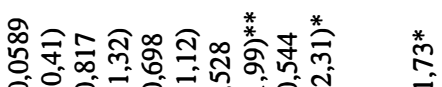


O teste $\mathrm{t}$ (entre parênteses) indicou que os coeficientes da equação dos indivíduos saudáveis foram mais significativos do que os coeficientes dos indivíduos doentes.

As variáveis idade, idade2, rendanãosalarial, chefe e filho foram, em quase todos as equações, significativas. $\mathrm{O}$ teste Qui-quadrado foi significativo a $1 \% \mathrm{em}$ todas regressões.

As variáveis com melhor ajustamento nas equações de rendimento foram idade, idade2, educação, urbano e bramarel. $\mathrm{O}$ teste $\mathrm{F}$ foi significativo a $1 \%$ em todas as regressões. Além disso, observa-se que a variável Lâmbda não foi significativa. Tal fato indica que não haveria problema de seletividade amostral devido a não inclusão de indivíduos adultos que não recebem salário.

Para a população feminina, na maioria dos casos, os valores das estimativas das perdas de rendimento foram negativos. Vale ressaltar que, apesar destes valores negativos para as perdas de rendimento serem metodologicamente possíveis, as comparações entre regiões e setores ficaram prejudicadas. 


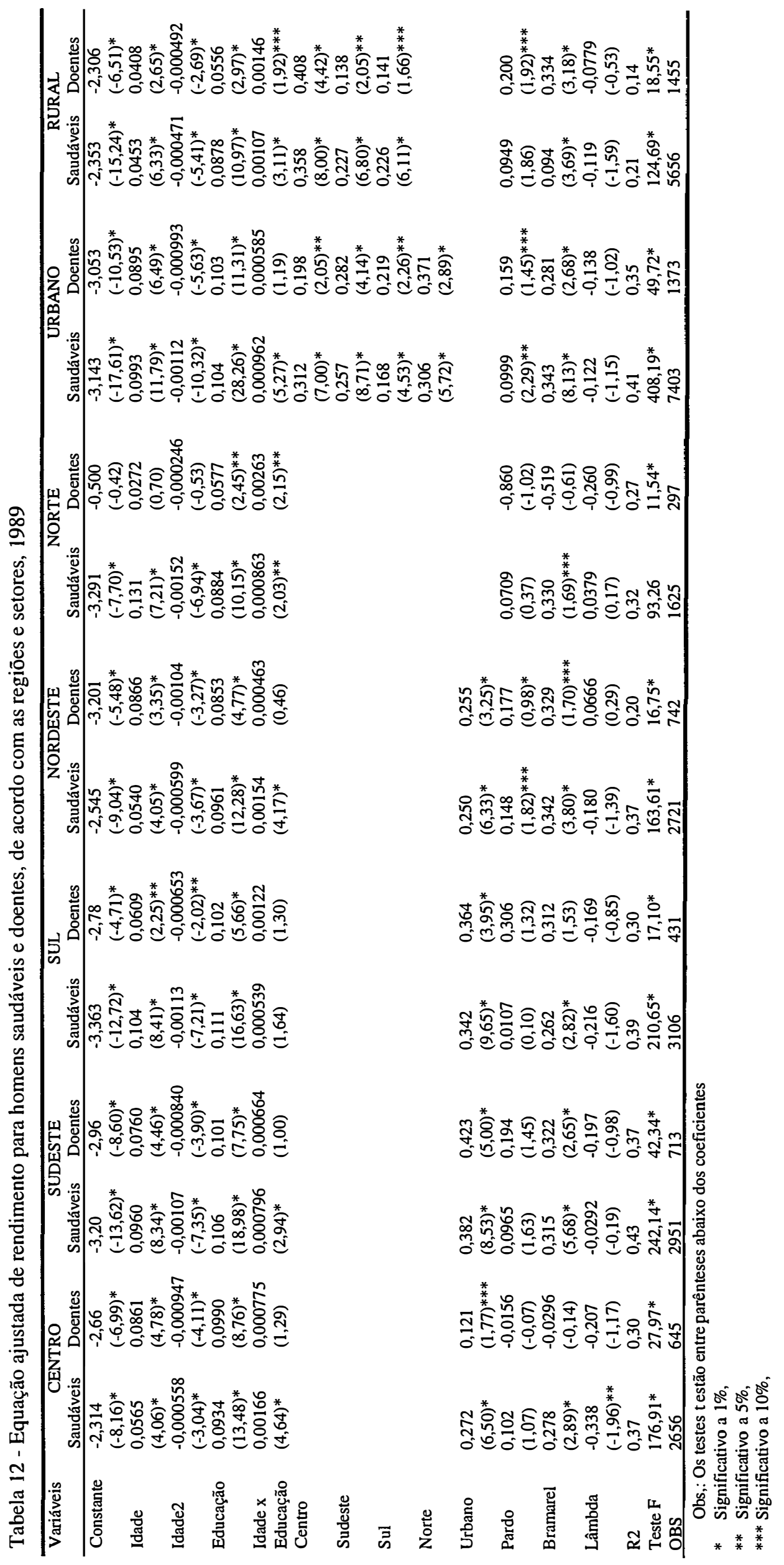


Neste estudo obtém-se as estimativas para dois tipos de perdas de rendimento.

O primeiro tipo de perda de rendimento inclui no seu cálculo apenas os doentes que estão fora do mercado de trabalho (Perda 1). A segunda perda refere-se aos doentes que participam da força de trabalho, mas têm rendimentos inferiores aos saudáveis (Perda 2).

As tabelas de participação no mercado de trabalho e rendimento, para as mulheres saudáveis e doentes, necessárias para o cálculo das diferenças ajustadas estão em anexo.

A Tabela 13 apresenta os cálculos das perdas de rendimento devido aos problemas de saúde para os homens adultos no Brasil por região e setor. Essa tabela é, em grande parte, auto explicativa. Os itens 4 e 12 são os únicos que necessitam de uma melhor explicação. O item 4 é obtido multiplicando-se os coeficientes estimados das equações de participação no mercado de trabalho para os saudáveis pelas médias das variáveis da amostra de indivíduos doentes. Já o item 12 é obtido multiplicando-se os coeficientes estimados nas equações de rendimentos dos indivíduos saudáveis pelas médias das variáveis exógenas da amostra de indivíduos doentes. O objetivo desse método é eliminar ou reduzir as diferenças na participação do mercado de trabalho e rendimento entre homens saudáveis e doentes devido a outros fatores, que não os problemas de saúde. 
Tabela 13 - Perdas de rendimento por hora em dólares para os homens adultos do Brasil, 1989.

\begin{tabular}{|c|c|c|c|c|c|c|c|c|c|c|c|c|c|}
\hline 覓| & $\begin{array}{l}m \\
0 \\
0 \\
0\end{array}$ & & 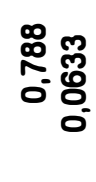 & 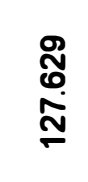 & 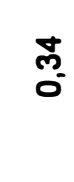 & 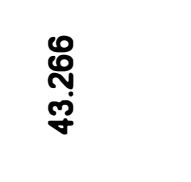 & 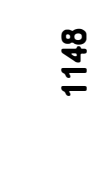 & 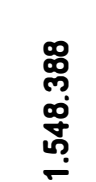 & $\frac{8}{6}$ & 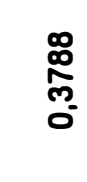 & & 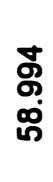 & 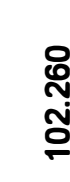 \\
\hline 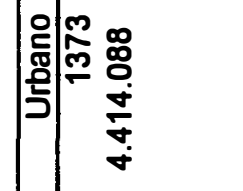 & $\underset{\substack{\mathfrak{N} \\
0 \\
0}}{ }$ & & $\begin{array}{l}\mathscr{0} \\
0.00 \\
0.0 \\
0\end{array}$ & $\begin{array}{l}\mathscr{8} \\
\stackrel{8}{8} \\
\stackrel{8}{0}\end{array}$ & $\begin{array}{c}\mathbb{N} \\
0\end{array}$ & 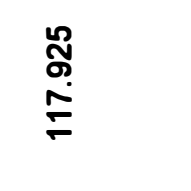 & 웅 & $\begin{array}{l}\stackrel{0}{0} \\
\stackrel{\leftrightarrow}{0} \\
\stackrel{0}{+} \\
\stackrel{n}{0}\end{array}$ & $\stackrel{\circ}{\stackrel{0}{0}}$ & $\begin{array}{l}\frac{9}{9} \\
\frac{0}{0} \\
0\end{array}$ & & 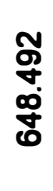 & ‡) \\
\hline 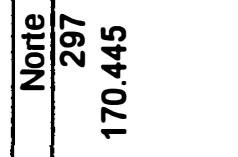 & $\begin{array}{l}\bar{n} \\
\infty \\
0 \\
0\end{array}$ & & 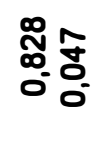 & $\underset{\infty}{\infty}$ & 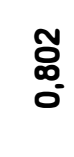 & 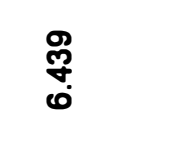 & $\bar{N}$ & 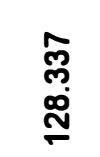 & : & $\bar{\Phi}$ & & $\begin{array}{l}\bar{\delta} \\
\stackrel{\sigma}{\sigma}\end{array}$ & 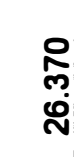 \\
\hline 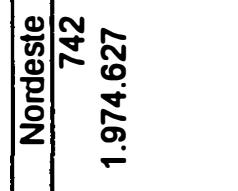 & 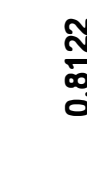 & & $\begin{array}{l}\stackrel{R}{R} \\
0 \\
0\end{array}$ & $\begin{array}{l}\stackrel{9}{\circ} \\
\stackrel{\text { }}{ }\end{array}$ & ֻొ & 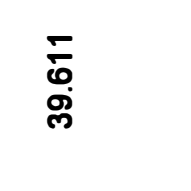 & న్రి & 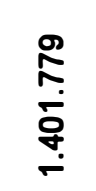 & 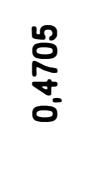 & $\begin{array}{c}0 \\
0 \\
0 \\
0 \\
0\end{array}$ & & 灾 & 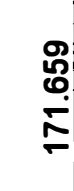 \\
\hline 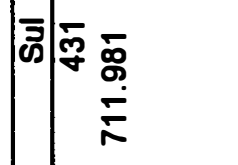 & 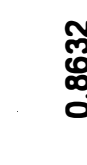 & & 牙是 & $\begin{array}{l}\text { 芯 } \\
\underset{\text { ల్ల }}{ }\end{array}$ & $\begin{array}{l}\text { : } \\
\text { : } \\
0 \\
0\end{array}$ & 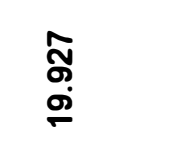 & 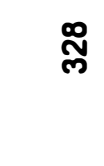 & 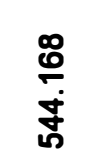 & $\begin{array}{c}\stackrel{N}{N} \\
\infty \\
0 \\
0\end{array}$ & $\begin{array}{l}\infty \\
0 \\
: \\
0 \\
0\end{array}$ & & $\begin{array}{l}\overline{1} \\
80 \\
8\end{array}$ & 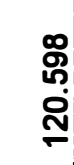 \\
\hline 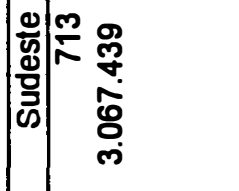 & $\begin{array}{l}8 \\
\stackrel{0}{0} \\
\infty \\
0 \\
0\end{array}$ & & 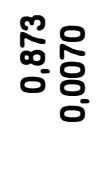 & 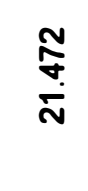 & $\underset{\stackrel{0}{0}}{\stackrel{0}{0}}$ & $\begin{array}{l}\stackrel{\mathscr{D}}{0} \\
\stackrel{\rho}{\rho}\end{array}$ & $\underset{\varpi ్}{\tilde{~}}$ & $\begin{array}{l}\stackrel{9}{\stackrel{9}{*}} \\
\stackrel{\text { Oे }}{\text { N }}\end{array}$ & $\stackrel{\infty}{\overleftarrow{8}}$ & 总 & $\frac{\infty}{\frac{\infty}{\sigma}}$ & $\begin{array}{l}\mathscr{\mathscr { g }} \\
\stackrel{\infty}{0} \\
\stackrel{9}{q}\end{array}$ & 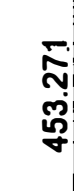 \\
\hline 仓ी & $\begin{array}{l}\mathscr{g} \\
\mathbb{8} \\
\mathbb{0} \\
0 \\
0 \\
0\end{array}$ & & 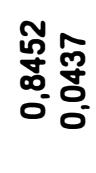 & 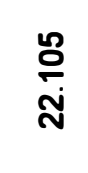 & $\underset{0}{0}$ & 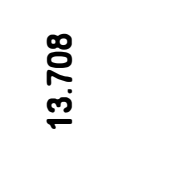 & జ్లి & $\stackrel{\stackrel{8}{\circ}}{\stackrel{\leftrightarrow}{\bar{j}}}$ & $\frac{0}{0}$ & 敢 & & $\begin{array}{l}\underset{f}{\sigma} \\
\stackrel{i}{N}\end{array}$ & $\frac{9}{\sigma}$ \\
\hline 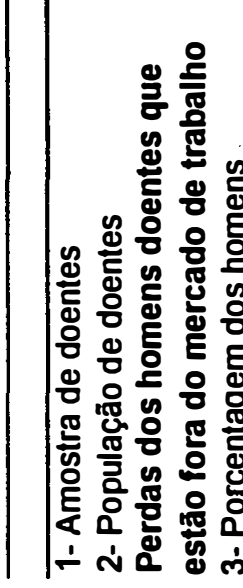 & 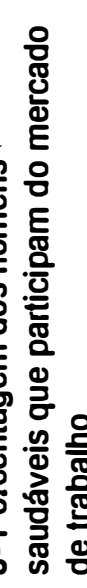 & 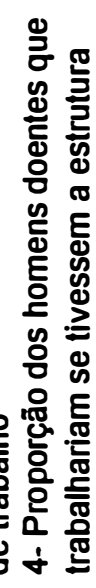 & . & 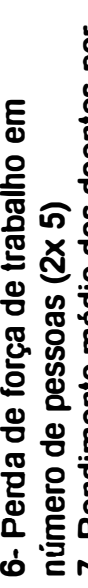 & 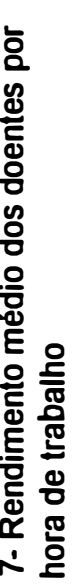 & 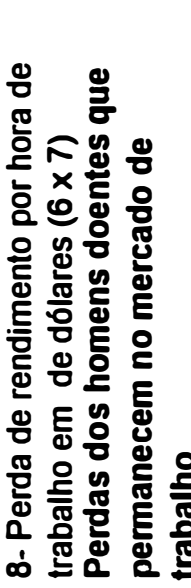 & 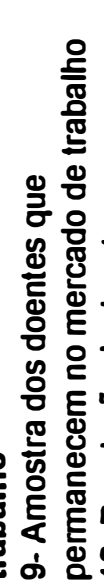 & 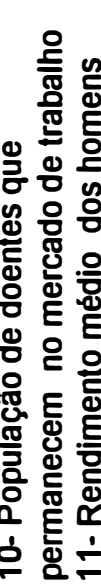 & 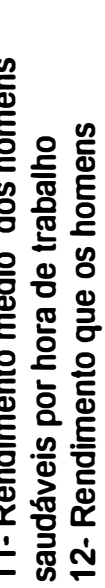 & 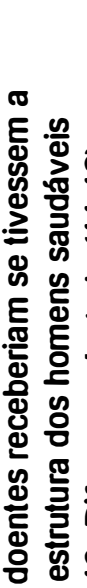 & 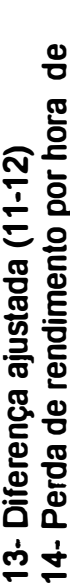 & & 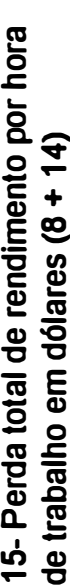 \\
\hline
\end{tabular}


Os resultados para a população masculina, apresentados na Tabela 13, indicam que as perdas de rendimento devido aos problemas relacionados a saúde são elevadas no Brasil.

A Figura 6, a seguir, indica que as perdas das pessoas que estão atuando no mercado de trabalho são superiores às perdas das pessoas que estão fora do mercado de trabalho. Nota-se que as regiões Norte e Nordeste apresentam as maiores perdas do tipo 1, assim como o setor rural. Já as regiões Sudeste, Sul e Centro-Oeste, e o setor urbano apresentam as maiores perdas do tipo 2 .

A hipótese levantada para explicar a maior participação percentual das perdas do tipo 2 em relação as perdas totais de rendimento é a de que as pessoas que participam do mercado de trabalho, mesmo com condições de saúde inadequadas possuem melhores empregos e, por consequiência, maior rendimento comparativamente as pessoas que estão fora do mercado de trabalho.. 


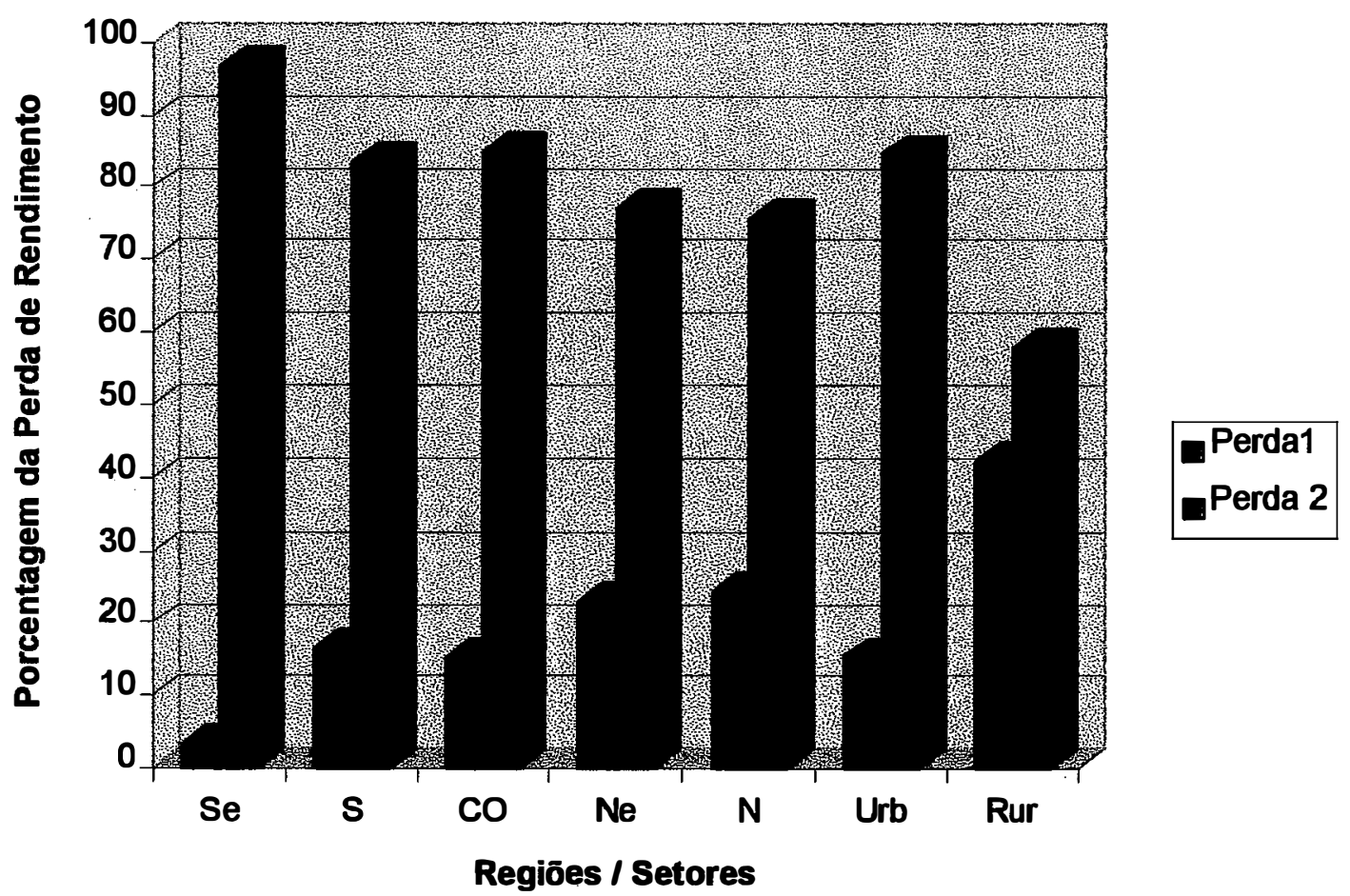

Figura 6 - Distribuição percentual das perdas de rendimento por hora de trabalho do tipo 1 e tipo 2 entre regiões e setores do Brasil, 1989.

Ao considerar-se a perda de rendimento total, que é obtida através do somatório das perdas 1 e 2, com relação a perda total nas cinco regiões, observa-se que as regiões Sudeste e Nordeste apresentam as maiores perdas percentuais com 52,5\% e 19,9\%, respectivamente. As regiões Sul, Centro-Oeste e Norte apresentam percentuais inferiores a 15\% (Figura 7).

Quando a comparação é feita entre os setores, verifica-se que o setor Urbano responde por $88,2 \%$ das perdas de rendimentos totais, sendo que o setor rural participa com apenas $11,8 \%$ das referidas perdas. Este resultado também é aceitável tendo em vista que os rendimento médio por hora de trabalho no setor Rural é de apenas US\$ 0,34 e, no setor Urbano é de US\$ 0,72. 


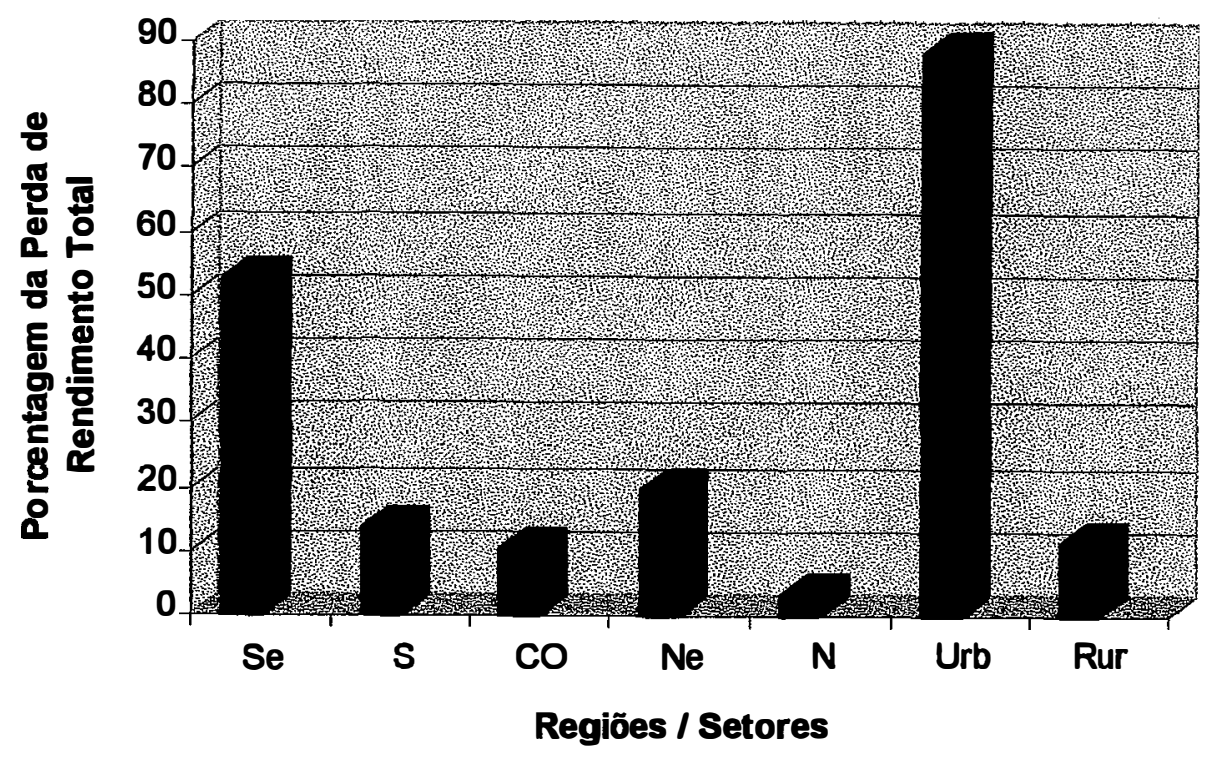

Figura 7 - Distribuição percentual das perdas de rendimento totais por hora de trabalho entre regiões e setores do Brasil, 1989.

Pode-se dizer que estes resultados são plenamente aceitáveis e, até mesmo, esperados. A região Sudeste apresenta elevada densidade demográfica e, conforme citado anteriormente no capítulo 4 , possui uma grande população de doentes. Já, a região Nordeste possui elevados índices de pobreza absoluta. É de se esperar, portanto, que as perdas de rendimento devido a condições inadequadas de saúde sejam elevadas nestas regiões.

Utilizando-se a idéia de capacidade potencial de horas de trabalho, proposta por Haveman (1995), as perdas totais de rendimento potencial por ano foram estimadas multiplicado-se as perdas de rendimento por hora de trabalho, o número máximo de horas de trabalho semanal permitido pela legislação trabalhista (40 horas), o número de semanas em um mês (4 semanas) e o número de meses em um ano (12 meses). Portanto, 
para obter-se a perda de rendimento potencial por ano é necessário multiplicar o valor das perdas de rendimento em horas por 1.920 (Tabela 14).

Tabela 14 - Perda total de rendimento por hora e perda potencial de rendimento por ano em milhões de dólares para a população masculina do Brasil, 1989.

\begin{tabular}{lcc}
\hline Regiões / Setores & $\begin{array}{c}\text { Perda Total de Rendimento } \\
\text { por Hora }\end{array}$ & $\begin{array}{c}\text { Perda Potencial de } \\
\text { Rendimento por Ano (US\$1 10 }\end{array}$ \\
\hline Centro-Oeste & 91.349 & 175,4 \\
Sudeste & 453.271 & 870,3 \\
Sul & 120.598 & 231,6 \\
Nordeste & 171.659 & 329,6 \\
Norte & 26.370 & 50,6 \\
Urbano & 766.417 & $1.471,5$ \\
Rural & 102.260 & 196,3 \\
Brasil Regiões & 863.247 & $1.657,4$ \\
Brasil Setores & 868.677 & $1.657,5$ \\
\hline
\end{tabular}

A perda potencial de rendimento por ano, para os homens do Brasil, considerando-se o somatório por região, atinge o valor de US\$1.657,4 bilhões. Ao se efetuar o somatório por setores o montante de perda potencial de rendimento chega a US\$ 1.657,5 bilhões. A diferença entre os dois critérios foi praticamente nula.

A Tabela 15, a seguir, mostra as estimativas das perdas de rendimento por hora para as mulheres adultas. Conforme citado anteriormente, na maioria dos casos os valores das perdas de rendimento 1 e perda de rendimento 2 foram negativos.

$\mathrm{O}$ valor negativo das estimativas das perdas de rendimento surgiram devido ao sinal negativo da diferença ajustada. A diferença ajustada na perdas de rendimento tipo 1 é calculada subtraindo-se a porcentagem de mulheres saudáveis que participam do 
mercado de trabalho menos a proporção das mulheres doentes que trabalhariam se tivessem a estrutura das mulheres saudáveis. Já o sinal negativo da diferença ajustada na estimativa das perdas tipo 2 ocorre devido ao fato de que o rendimento médio das mulheres saudáveis foi na maioria dos casos, inferior ao rendimento médio que as mulheres doentes receberiam se tivessem a estrutura das mulheres saudáveis. 
Tabela 15 - Perdas de rendimento por hora em dólares para as mulheres adultas do Brasil, 1989.

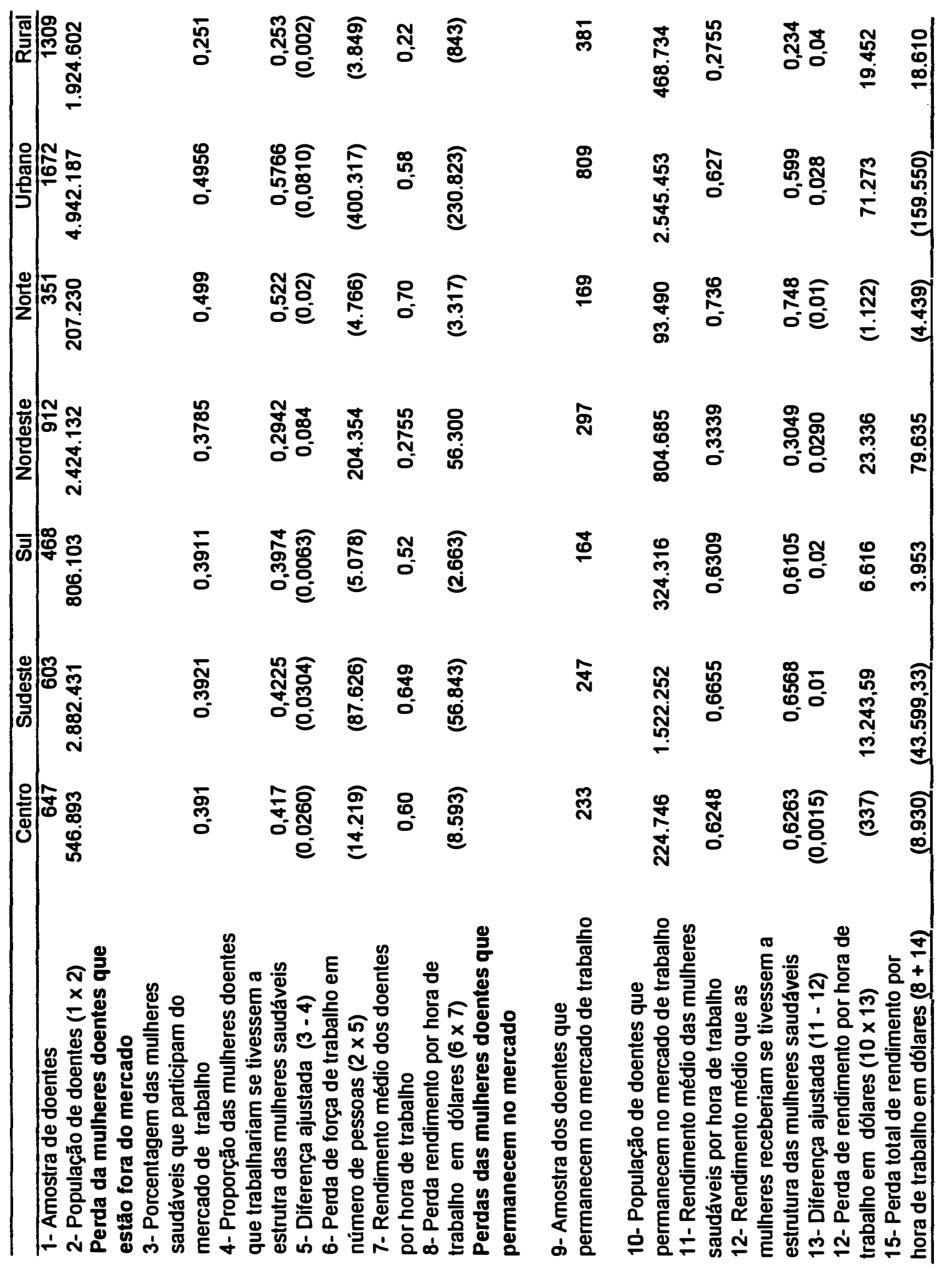


No tocante as perdas de rendimento nas regiões pode-se dizer que apenas a região Nordeste apresentou perda de rendimento positiva nas perdas tipo 1 e 2 . A perda tipo 1 ficou em US $\$ 56.300$, correspondendo a $70,66 \%$ das perdas de rendimentos totais, e as perdas tipo 2 ficaram em US\$23.336, correspondendo a $29,34 \%$ das referidas perdas. A perda total de rendimento nesta região chegou a atingir US\$ 79.636. Além disso, vale destacar que a região Sul apresentou uma pequena perda total de rendimento que atingiu US\$ 3.953 por hora de trabalho.

No que refere-se aos setores apenas o setor Rural apresentou perda total positiva com o valor de US\$ 18.610 por hora de trabalho.

Apesar das estimativas das perdas de rendimento por hora para as mulheres brasileiras serem incompletas, uma importante constatação pode ser feita. A participação no mercado de trabalho e o salário médio dos homens saudáveis são significativamente maiores do que os das mulheres. Apesar da necessidade de um estudo aprofundado, este fato pode ser considerado um indício de discriminação contra a mulher. Conforme o Relatório sobre o Desenvolvimento Humano no Brasil (1996) estudos empíricos sobre a discriminação por gênero mostram que os salários das mulheres são sistematicamente menores do que os dos homens (cerca da metade). Além disso, esse diferencial salarial por gênero tem se mostrado relativamente constante ao longo do tempo, não demonstrando qualquer tendência ao declínio.

\subsection{As equações de saúde}

As equações de saúde estimadas por mínimos quadrados ponderados pelo fator de expansão da amostra são apresentadas nas Tabelas 16 e 17 . Observa-se que o objetivo principal destas equações é o de captar o relacionamento do estado de saúde com as condições de saneamento básico e de salubridade da população adulta. 
Tabela 16 - Equações de saúde para homens e mulheres normais e de baixo peso (IMC

\begin{tabular}{|c|c|c|}
\hline Variáveis & Homens & Mulheres \\
\hline Constante & $\begin{array}{l}16,2334 \\
(72,31)^{*}\end{array}$ & $\begin{array}{l}17,259 \\
(67,24)^{*}\end{array}$ \\
\hline Educação & $\begin{array}{l}0,0724 \\
(11,29)^{*}\end{array}$ & $\begin{array}{l}-0,0628 \\
(-8,67)^{*}\end{array}$ \\
\hline Idade & $\begin{array}{l}0,268 \\
(24,21)^{*}\end{array}$ & $\begin{array}{l}0,241 \\
(19,36) *\end{array}$ \\
\hline Idade2 & $\begin{array}{l}-0,00280 \\
(-19,95)^{*}\end{array}$ & $\begin{array}{l}-0,00238 \\
(-15,054)\end{array}$ \\
\hline Bramarel & $\begin{array}{l}0,00389 \\
(0,039)\end{array}$ & $\begin{array}{l}-0,293 \\
(-2,50)\end{array}$ \\
\hline Pardo & $\begin{array}{l}-0,0389 \\
(-0,38)\end{array}$ & $\begin{array}{l}-0,328 \\
(-2,74)\end{array}$ \\
\hline Norte & $\begin{array}{l}0,549 \\
(3,95)^{*}\end{array}$ & $\begin{array}{l}0,381 \\
(2,45)\end{array}$ \\
\hline Centro-Oeste & $\begin{array}{l}0,310 \\
(3,22)^{*}\end{array}$ & $\begin{array}{l}0,215 \\
(1,97)\end{array}$ \\
\hline Sudeste & $\begin{array}{l}-0,0471 \\
(-0,705)\end{array}$ & $\begin{array}{l}0,394 \\
(5,26)^{*}\end{array}$ \\
\hline Sul & $\begin{array}{l}0,697 \\
(8,55)^{*}\end{array}$ & $\begin{array}{l}0,639 \\
(6,96)^{*}\end{array}$ \\
\hline Urbano & $\begin{array}{l}-0,207 \\
(-2,49)\end{array}$ & $\begin{array}{l}-0,205 \\
(-2,056)\end{array}$ \\
\hline Rendanãosalarial & $\begin{array}{l}0,000461 \\
(3,205)^{*}\end{array}$ & $\begin{array}{l}0,000822 \\
(2,46)^{*}\end{array}$ \\
\hline Fuma & $\begin{array}{l}-0,0218 \\
(-9,78)^{*}\end{array}$ & $\begin{array}{l}-0,0291 \\
(-7,58)^{*}\end{array}$ \\
\hline Abastecimentoágua & $\begin{array}{l}0,331 \\
(4,37)^{*}\end{array}$ & $\begin{array}{l}0,339 \\
(3,95)^{*}\end{array}$ \\
\hline Esgoto & $\begin{array}{l}0,135 \\
(2,08)\end{array}$ & $\begin{array}{l}0,0315 \\
(0,44)\end{array}$ \\
\hline Lixo & $\begin{array}{l}0,488 \\
(5,87)^{*}\end{array}$ & $\begin{array}{l}0,234 \\
(3,072) *\end{array}$ \\
\hline Luz & $\begin{array}{l}0,486 \\
(5,87)^{*}\end{array}$ & $\begin{array}{l}1,051 \\
(10,32) *\end{array}$ \\
\hline $\begin{array}{l}\text { Teste } F \\
\mathrm{R}^{2}\end{array}$ & $\begin{array}{l}140,795 * \\
0,13\end{array}$ & $\begin{array}{l}109,705^{*} \\
0,10\end{array}$ \\
\hline
\end{tabular}

Obs.: Os testes t estão entre parênteses abaixo dos coeficientes.

* Indica significativo a $1 \%$.

${ }^{21} \mathrm{O}$ Índice de Massa Corporal é a variável dependente. 
Tabela 17 - Equações de saúde para homens e mulheres normais, com sobrepeso e obesidade (IMC $\geq 20$ ) de 18 a 65 anos $^{22}$.

\begin{tabular}{|c|c|c|}
\hline Variáveis & Homens & Mulheres \\
\hline \multirow[t]{2}{*}{ Constante } & 17,054 & 18,40 \\
\hline & $(62,10)^{*}$ & $(53,52)^{*}$ \\
\hline \multirow[t]{2}{*}{ Educação } & 0,0595 & $-0,0857$ \\
\hline & $(8,02)^{*}$ & $(-9,10)^{*}$ \\
\hline \multirow[t]{2}{*}{ Idade } & 0,260 & 0,268 \\
\hline & $(19,50)^{*}$ & $(16,39)^{*}$ \\
\hline \multirow[t]{2}{*}{ Idade 2} & $-0,00262$ & $-0,00237$ \\
\hline & $(-15,56)^{*}$ & $(-11,61)^{*}$ \\
\hline \multirow[t]{2}{*}{ Bramarel } & 0,254 & $-0,795$ \\
\hline & $(2,16)$ & $(-5,33)^{*}$ \\
\hline \multirow[t]{2}{*}{ Pardo } & $-0,0327$ & $-0,598$ \\
\hline & $(-0,27)$ & $(-3,90)^{*}$ \\
\hline \multirow[t]{2}{*}{ Norte } & 0,617 & 0,462 \\
\hline & $(3,81)^{*}$ & $(2,45)$ \\
\hline \multirow[t]{2}{*}{ Centro-Oeste } & 0,364 & 0,552 \\
\hline & $(3,18)^{*}$ & $(1,97)^{*}$ \\
\hline \multirow[t]{2}{*}{ Sudeste } & $-0,00596$ & 0,576 \\
\hline & $(-0,074)$ & $(5,76)^{*}$ \\
\hline \multirow[t]{2}{*}{ Sul } & 0,634 & 1,079 \\
\hline & $(6,66)^{*}$ & $(8,97)^{*}$ \\
\hline \multirow[t]{2}{*}{ Urbano } & $-0,164$ & $-0,193$ \\
\hline & $(-1,619)$ & $(-1,468)$ \\
\hline \multirow[t]{2}{*}{ Rendanãosalarial } & 0,000864 & 0,000385 \\
\hline & $(5,006)^{*}$ & $(0,96)$ \\
\hline \multirow[t]{2}{*}{ Fuma } & $-0,0206$ & $-0,0324$ \\
\hline & $(-7,94)^{*}$ & $(-6,45)^{*}$ \\
\hline \multirow[t]{2}{*}{ Abastecimentoágua } & 0,592 & 0,492 \\
\hline & $(6,51)^{*}$ & $(4,37)^{*}$ \\
\hline \multirow[t]{2}{*}{ Esgoto } & 0,307 & 0,166 \\
\hline & $(4,03)^{*}$ & $(1,78)$ \\
\hline \multirow[t]{2}{*}{ Lixo } & 0,444 & $-0,229$ \\
\hline & $(5,54)^{*}$ & $(-0,23)$ \\
\hline \multirow[t]{2}{*}{ Luz } & 0,436 & 1,264 \\
\hline & $(4,29)^{*}$ & $(9,13)^{*}$ \\
\hline Teste F & $132,866^{*}$ & $114,508^{*}$ \\
\hline $\mathrm{R}^{2}$ & 0,14 & 0,12 \\
\hline
\end{tabular}

Obs.: Os testes t estão entre parênteses abaixo dos coeficientes.

* Indica significativo a $1 \%$.

22 O Índice de Massa Corporal é a variável dependente. 
Entretanto, outras variáveis foram incluídas para ampliar a análise dos fatores que contribuem para um melhor estado de saúde.

Ressalte-se que a maioria dos coeficientes estimados são significativos a $1 \%$ de probabilidade.

Os coeficientes encontrados na variável Educação são significativos a $1 \%$ de probabilidade nas quatro equações. $O$ sinal positivo do coeficiente na equação masculina confirma a teoria pois a educação tem efeitos benéficos a saúde. Entretanto, o sinal negativo encontrado para as equações para mulheres foi inesperado.

Os coeficientes das variáveis Idade e Idade2 são significativos a $1 \%$ de probabilidade. Além disso, o sinal positivo da variável Idade e o sinal negativo da variável Idade2 indicam uma relação parabólica. O sinal positivo encontrado para a variável Idade é esperado tendo em vista que é grande a parcela de jovens com problema de baixo peso.

Os coeficientes encontrados nas variáveis raça, Bramarel e Pardo não são estatisticamente significativos para explicar melhor condição de saúde. Apenas a variável Bramarel na equação das mulheres com IMC $\geq 20$ foi significativa a $1 \%$ de probabilidade. Entretanto, o sinal negativo não é o esperado pois os brancos possuem melhores condições e acesso à saúde comparativamente aos negros.

A região Nordeste (relativamente pobre) foi omitida para permitir a sua comparação com as demais regiões. As variáveis regionais são quase todas significativas a $1 \%$ e apresentaram na sua maioria coeficientes positivos, conforme o esperado. A única exceção foi a região Sudeste que apresentou sinal negativo para os homens nas duas equações. 
A variável Urbano não foi significativa para explicar melhor condição de saúde.

Com exceção da equação para mulheres com IMC $\geq 20$, os coeficientes referentes a variável Rendansalarial foram significativos a $1 \%$ de probabilidade. Além disso, eles apresentaram sinal positivo pois quanto maior o rendimento melhores condições terá o indivíduo para alocar recursos em alimentação, consultas médicas e remédios.

Os coeficientes estimados para a variável Fuma, que indica o número de cigarros fumados ao dia, foram estatisticamente significativos e apresentaram sinais negativos, conforme o esperado.

No que refere-se a infra-estrutura do domicilio, as variáveis Abastecimentoágua, Esgoto, Lixo e Luz, apresentaram sinais positivos, indicando efeito positivo sobre a saúde, conforme o esperado. Todas as variáveis relacionadas a infra-estrutura do domicilio, com exceção da variável esgoto para as mulheres e homens com IMC $<30$, foram significativas a $1 \%$ de probabilidade. Na equação para mulheres com IMC $\geq 20$ as variáveis Esgoto, Lixo e Luz não foram significativas. Entretanto, a equação para homens indica que todas as variáveis foram significativas a $1 \%$ de probalidade, confirmando a hipótese de que o saneamento básico provoca um efeito positivo na saúde.

A partir dessa afirmação, algumas considerações sobre a alocação dos recursos públicos no setor de saúde e saneamento básico podem ser feitas. Antes porém, torna-se necessário analisar a oferta de serviços de saúde e saneamento básico no Brasil.

O primeiro aspecto a ser analisado refere-se a oferta de serviços de saúde, ou seja, o conjunto de hospitais, ambulatórios e leitos, assim como a produção de serviços de saúde caracterizadas pelas consultas e internações. 
De acordo com Medici (1997), os anos 80 foram caracterizados por um forte crescimento da oferta de saúde, especialmente no que se refere aos estabelecimentos públicos. Ainda de acordo com o autor, entre os anos de 1980 e 1989 o número de hospitais públicos passou de 1217 para 1966, e o número de estabelecimentos públicos sem serviços de internação passou de 8828 para 20817, atingindo uma taxa de crescimento de $61,5 \%$ e $135,8 \%$, respectivamente.

Conforme pode ser visualizado na Figura 8 , o crescimento do número de hospitais públicos na década de 80 foi maior nas regiões Norte, Nordeste e CentroOeste; notadamente as mais carentes em relação a oferta de serviços de saúde.

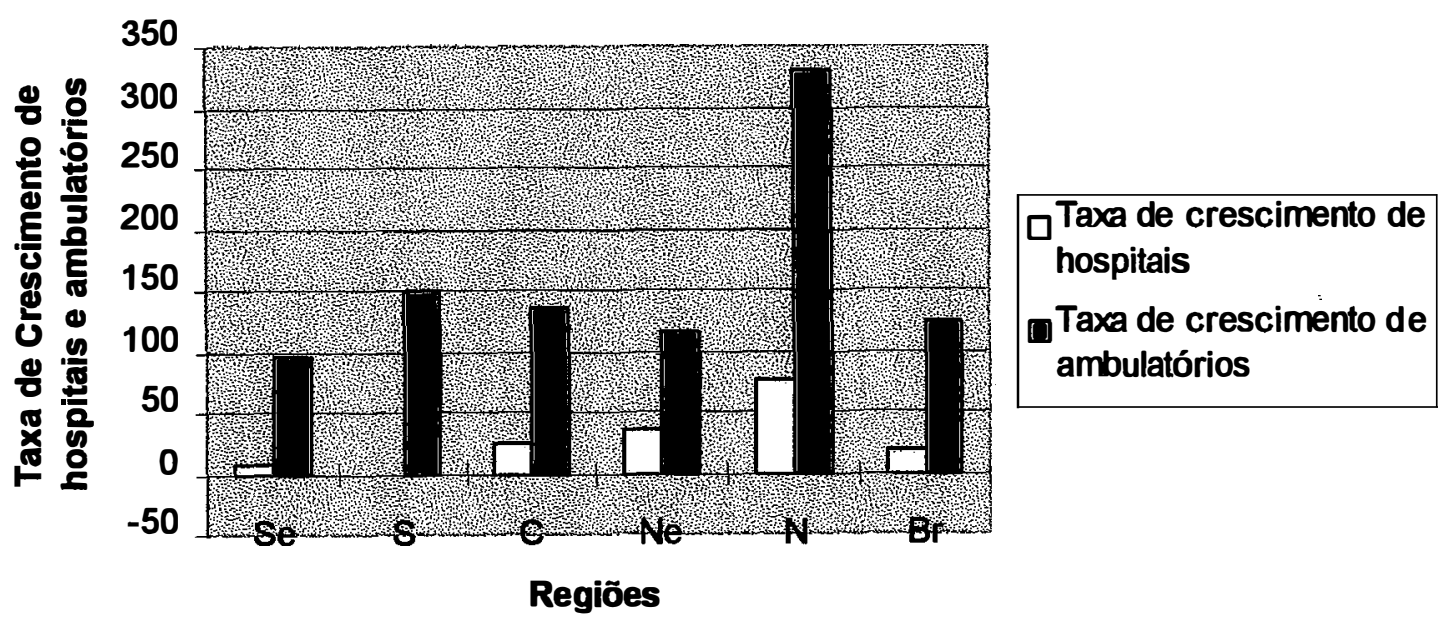

Fonte: Medici (1997).

Figura 8 - Taxa de crescimento de hospitais e ambulatórios nas regiões e Brasil entre 1980 e 1989.

O crescimento do número de hospitais na região Sudeste foi tímido e na região Sul houve um decréscimo de cerca de $2 \%$. Quanto aos estabelecimentos ambulatoriais observa-se que ocorreu um acréscimo em todos as regiões. No Brasil a taxa de 
crescimento de hospitais e ambulatórios entre 1980 e 1989 ficou em 17,9\% e 123,8\%, respectivamente.

Outro fato importante a ser destacado é a forte evidência de que o número de leitos é elevado. A Tabela 18 demostra que apesar do crescimento do número de hospitais; o número de leitos hospitalares declinou de 4,3 para 3,7/1.000 habitantes, entre 1980 e 1989. A hipótese para o declínio do índice de leitos e ambulatórios por 1000 habitantes é de que a capacidade instalada não esteja sendo utilizada plenamente. Há um forte indicio de que esteja ocorrendo o fechamento de leitos e ambulatórios no Brasil.

Tabela 18 - Oferta de leitos por 1.000 habitantes e 1.000 habitantes por ambulatório no Brasil, 1989.

\begin{tabular}{lccccc}
\hline Regiões & $\begin{array}{l}\text { Leitos } \\
\text { habitantes }\end{array}$ & por & 1.000 & $\begin{array}{l}1.000 \\
\text { ambulatório }\end{array}$ & habitantes \\
\cline { 2 - 5 } & 1980 & 1989 & 1980 & 1989 \\
\hline Sudeste & 2,8 & 2,1 & 14,1 & 4,6 \\
Sul & 2,6 & 2,9 & 9,1 & 5 \\
Centro-Oeste & 5,3 & 4,3 & 8,3 & 3,8 \\
Nordeste & 5,1 & 5,2 & 9,9 & 5,9 \\
Norte & 4,6 & 4,2 & 11,8 & 6,5 \\
Brasil & 4,3 & 3,7 & 9,6 & 5,1 \\
\hline
\end{tabular}

Fonte: Medici (1995).

O acesso a serviços de saneamento básico no Brasil apresenta profundas diferenças entre os estratos sociais. De acordo com o Relatório sobre o Desenvolvimento Humano no Brasil (1986), entre os anos de 1981 e 1990, as parcelas da população urbana mais pobre, com renda até um salário mínimo e entre um e dois salários mínimos, com acesso a esses serviços ( $33 \%$ e $41 \%$, respectivamente), mantiveram-se em patamar muito inferior a média nacional de $69 \%$. 
Quando a questão do acesso a serviços de saneamento básico é analisada entre as regiões e setores brasileiros, constata-se que as regiões mais ricas são privilegiadas. Neste sentido o Relatório sobre o Desenvolvimento Humano no Brasil (1986) indica que as regiões Sul e Sudeste apresentam a cobertura do serviço de água potável acima da média de 80,87\%. Além disso, essas mesmas regiões possuem o maior índice de esgoto urbano coletados por estações de tratamento. As regiões mais pobres, como por exemplo, as regiões Norte e Nordeste apresentam níveis de tratamento de esgoto menores que $1 \%$; comparativamente a média nacional que, apesar de baixa, chega a $10 \%$.

As informações sobre o acesso de serviços de saneamento no setor rural são pouco precisas, mas de acordo com o Relatório sobre Desenvolvimento Humano no Brasil (1986) as estimativas de 1990 indicavam que a cobertura do serviço da rede geral de abastecimento de água situava-se em $16 \%$ e de coleta de esgoto, em aproximadamente $5 \%$.

O limitado acesso ao serviço de saneamento básico no Brasil demonstra que a necessidade de investimento é elevada. A Tabela 19 demonstra que com base nos preços de obras de saneamento no ano de 1990 e com tecnologias convencionais (cenário I) para suprir os serviços públicos de coleta e tratamento, seriam necessários investimentos estimados em US\$15,3 bilhões. Já se o cenário II for adotado, o total de investimentos necessários para atender a população excluída dos serviços de saneamento básico, seria de US\$ 11,5 bilhões, também a preços de 1990. Dependendo do tipo de cenário adotado, as despesas anuais totais ficariam em torno de US\$ 1,5 bilhões e US\$ 2 bilhões, considerando uma taxa de desconto de $12 \%$, uma vida útil superior a cinquenta anos e um custo de operação e manutenção de $10 \%$ sobre o investimento estimado. 
Tabela 19 - Necessidades de investimento em saneamento urbano no Brasil em milhões de dólares, 1990.

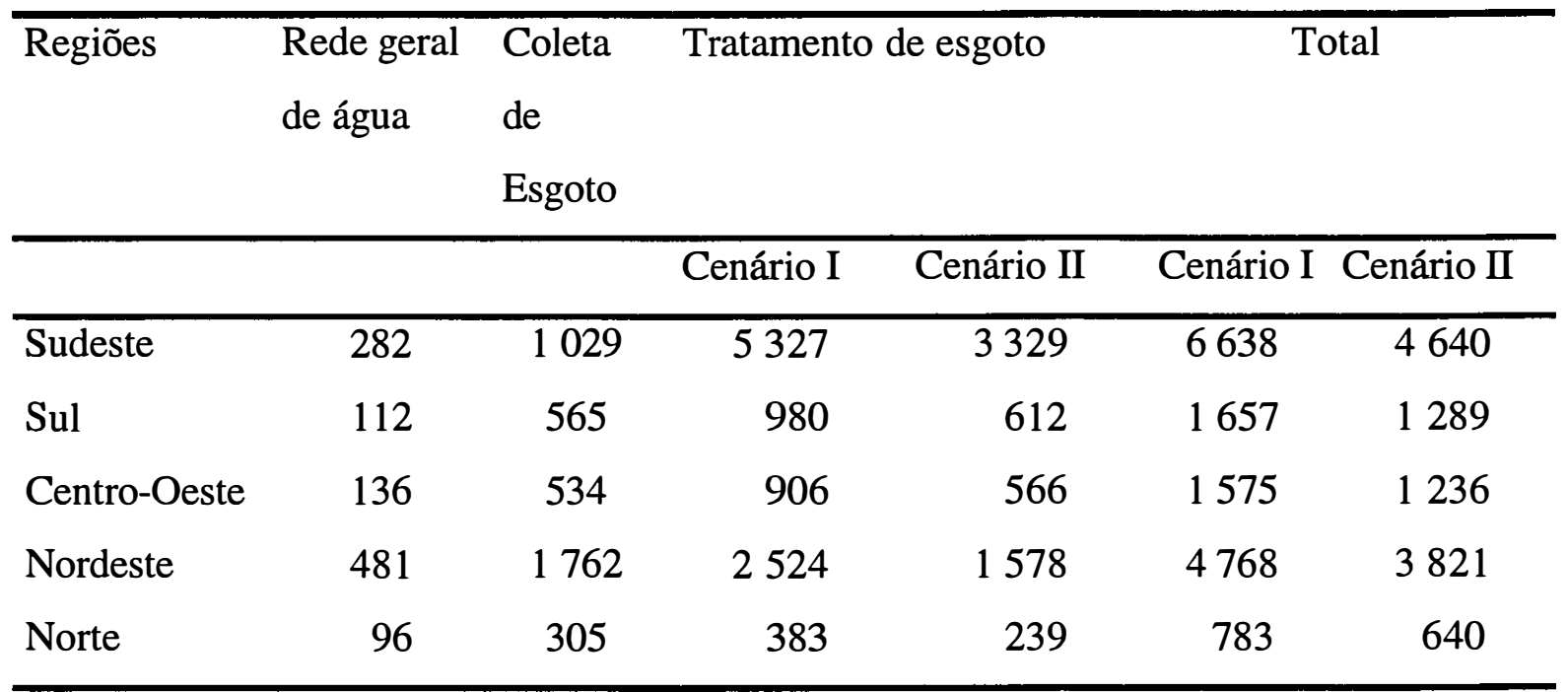

Fonte: Relatório sobre Desenvolvimento Humano no Brasil (1986).

Cenário I - Tratamento secundário de esgoto a $100 \%$ da população não atendida

Cenário II - Tratamento secundário de esgoto a 50\% da população não atendida

O estudo da oferta dos serviços de saúde e saneamento básico indicam haver uma prioridade para os investimentos em hospitais e ambulatórios comparativamente aos investimentos em saneamento básico. Essa estratégia provoca uma grave distorção na alocação dos recursos públicos na área de saúde, tendo em vista que existem indícios de que o número de leitos hospitalares é elevado e a necessidade de investimento em saneamento básico é significativa.

Em termos de viabilidade econômica os investimentos na área de saneamento são extremamente viáveis pois os custos das mortes, dos tratamentos e das internações causadas pela falta de infra-estrutura são enormes. De acordo com Barros et al (1996), a queda acentuada da mortalidade pelas doenças infecciosas e parasitárias não é acompanhada de uma redução, na mesma magnitude, na morbidade por este grupo de patologia, que ocupa o terceiro lugar em termos do total de internações. Essas doenças 
possuem custos elevado para o sistema de saúde, além de provocarem acentuadas perdas na produção e no rendimento do trabalhador que atua na força de trabalho.

Cabe destacar que as classes de renda menos elevadas continuam sendo excluídas do sistema de saneamento e, portanto, sujeitas as doenças que tem como causa a contaminação de água e a inexistência de serviços de esgoto. Portanto, pode-se concluir que o investimento em saneamento básico também possui viabilidade social, podendo ser um importante mecanismo para amenizar as enormes desigualdades sócioeconômicas; além de aumentar eficiência alocativa dos recursos públicos na área de saúde. 


\section{CONCLUSÕES}

Este estudo teve como objetivos básicos a estimativa das perdas de rendimento devido as condições adversas de saúde e as estimativas de equações de saúde.

As perdas de rendimento foram todas positivas para a população masculina, possibilitando comparações entre as regiões e os setores brasileiros.

As perdas de rendimento dos indivíduos que estão atuando no mercado de trabalho foram superiores às perdas dos homens que estão fora do mercado de trabalho quando se considera a amostra masculina. Além disso, as estimativas demonstraram que as regiões com maiores perdas foram a Sudeste e a Nordeste que, juntas, responderam por mais de $70 \%$ das perdas de rendimento totais. No que refere-se aos setores, as estimativas indicaram que o setor Urbano atingiu quase $90 \%$ das perdas de rendimentos totais.

As estimativas das perdas de rendimento para a população de mulheres indicaram que a região Nordeste foi a única que apresentou perdas de rendimento elevada. A região Sul apresentou uma pequena perda de rendimento e o setor Rural foi o que apresentou perda de rendimento. As estimativas das perdas de rendimento para as mulheres não permitiram inferências sobre as perdas de rendimento totais devido aos sinais negativos encontrados para a maioria das regiões e o setor Urbano. Entretanto, 
evidências de discriminação contra a mulher no mercado de trabalho surgiram com a comparação dos rendimentos médios dos homens e mulheres saudáveis.

Os coeficientes estimados nas equações de saúde foram, na sua maioria, significativos a $1 \%$ de probabilidade.

As variáveis relacionadas incluídas no modelo para captar outros fatores, que não o relacionamento das condições de saneamento básico e condições de salubridade, na sua maioria, apresentaram os resultados esperados.

No que refere-se a infra-estrutura do domicilio, objetivo principal das equações de saúde, as variáveis Abastecimentoágua, Esgoto, Lixo e Luz, com raras exceções, demonstraram provocar um efeito positivo na saúde, confirmando a idéia de que o saneamento básico possui grande importância para melhores condições de saúde.

Em conclusão, pode-se dizer que este estudo tem como mérito demonstrar que as perdas de rendimento devido as condições de saúde adversas são elevadas no Brasil (principalmente para população masculina) e que o saneamento básico é um importante fator para explicar melhor saúde tanto para os homens como para as mulheres.

É certo que os serviços de saúde não possuem, por si só, a capacidade de atenuar as macrodiferenças existentes nos padrões de saúde. Isto ocorrerá em consequência de um amplo processo de desenvolvimento econômico e da intensificação de políticas sociais, como aquelas direcionadas para as questões de saneamento básico e para a melhoria do estado nutricional da população. 


\section{REFERÊNCIAS BIBLIOGRÁFICAS}

AZIZ, F. Nutrition, health and labor productivity analysis of male and female workes: a test of the efficiency wage hypothesis. Minneapolis, University of Minnesota, 1995. 66 p. (Bulletim Number 95-5).

BARRERA, A. The role of maternal schooling and its interaction with public health programs in child health production. Journal of Development Economics, v.3, p.69-91, 1990.

BARROS, E. M.; Piola, S. F.; Vianna, S. M. Política de saúde no Brasil: Diagnóstico e perspectivas. IPEA, Brasília, n. 401, 1996. 123 p.

BECKER, G. S. Human Capital. New York: The University of Chicago Press. NBER, 1964. 390p.

A theory of the allocation of time. The Economic Journal, v.75, p.493$517,1965$.

A treatise of the family. Cambridge: Harvard University Press. 1981.

BLISS, C.; P. Stern. Productivity, wages and nutrition. Journal of Development Economics, v.5, p. 331-362, 1978. 
BOWEN, W. G.; Finagan, A. The economics of labor force participation. Princeton. Princeton University Press, 1969. 390p.

CENSO DEMOGRÁFICO -1991. Rio de Janeiro, FIBGE, 1994.

COOPER, B. S.; Rice D. P. The economic cost of illness revised. Social Security Bulletim, v.39, p.21-36, 1976.

DAVIS, J. M. Impact of health on earnings and labor market activity. Monthly Labor Review, Oct. p-46-49, 1972.

DOMAR, E. Capital expansion, rate of grow and employment. Econometrica, april, 1946.

FEBRERO, R. \& SCHWARTZ, P. S. The essence of Becker. Stanford: Hoover Institution Press, 1995. 669p.

FOLLAND, S.; Goodman, A. C.; Stano, M. The economics of health and health care. New York: Library of Congress. 1993. 726p.

HARROD, R. F. An essay in dynamic Theory. Economic Journal. v.49, p.14-33, 1939.

HAVEMAN, R.; Wolfe, B \& Buron, L. The loss of earnings capability disability/health limitations: toward a new social indicator. Review of Income and Wealth, v.41, n.3, 1995.

HECKMAN, J. Shadow prices, market wages, and labor supply. Econometrica, v.1, p.679-694, 1974. 
- Sample selection bias as a specification error. In: Smith, J.P. Female

labor suply: Theory and estimation. Princeton University Press, 1980. p206-248..

HELENA ALVIM, C. B. Família: indicadores sociais. Rio de Janeiro:IBGE/DEIS,1989. 27p.

HOFFMANN, R. Distribuição da renda e despesas com alimentação em 11 áreas urbanas do Brasil. Anais do XXXI Congresso Brasileiro de Economia e Sociologia Rural. Ilhéus, v.1, p.113-26.1993.

INAN/IBGE/ IPEA. Pesquisa nacional sobre saúde e nutrição. Brasília. 1989.

INAN. Pesquisa nacional sobre saúde e nutrição: condições nutricionais da população brasileira. Brasília. 1991

JAMES, W. P. T.; FERRO-LUZZI, A; WATERLOW, J. C. Definition of chronic energy in adults. European Journal of Clinical Nutrition. v. 42, p.969-981. 1988.

KASSOUF, A.L. Estimation of health demand and health production functions for children in Brasil. Minessota,1993. 135p. Thesis (Ph. D.) - University of Minessota. . Função de produção de saúde em diferentes regiões e setores do Brasil. Pesquisa \& Planejamento Econômico, v.23, n.3, p.547-570, 1993. . The wage rate estimation using the heckman procedure. Revista de Econometria, v.14, n.1, p.89-107, 1994.

- Saneamento e educação: bens substitutos ou complementares?. Pesquisa \& Planejamento Econômico, v.24, n.2, p.235-260, 1995. 
A saúde dos adultos e o seus rendimentos no meio rural. In: Teixeira,

E. C. \& VIEIRA W. C., ed. Reforma da política agrícola e abertura econômica. Viçosa-MG, 1996.

KUZNETS, S. Capital in American Economy. Princeton University Press, 1961.

LEIBENSTEIN, H. Economic Backwardness and Economic Growth. New York: John Wiley and Sons.1957.

. The teory of underemployment in densely populated backward areas.

In: Akerlof \& Yellen, ed. Efficiency Wage Models of Labor Market. Cambridge University Press.1986

LUCAS, R. E. On the mechanics of Economic Development. Journal of Monetary Economics. v.22, p.3-42. 1988.

LUFT, H. S. The impact of poor health on earnings. The review of Economics and Estatistics, 1974.

MADDALA, G. S. Limited Dependent Variables in Econometrics. New York. Cambridge University Press.1983.

MARTINS,G. Benefícios e custos do abastecimento de água e esgotamento sanitário em pequenas comunidades. São Paulo, 1995. FSP/USP. Dissertação de (M.S) Universidade de São Paulo.

MEDICE, A. C.; BELTRÃO, K I.Transição demográfica no Brasil: uma agenda para pesquisa. Planejamento e Políticas Públicas. v.12, n.2, p.199-212, 1996. 
MEDICE, A. C. Perfil da saúde no Brasil. Rio de Janeiro:IPEA, 1997, 189p.

MERRICK, T. The effect of piped water on early childhood mortality in urban Brazil, 1970 to 1976. Demography, v.13, p.87-104, 1985.

MINCER, J. On-the-job training: costs, returns, and some implications. Journal of Political Economic. v.70, n.5, p. 59-70, 1962.

MIRLEES, J.A. A pure underdeveloped economics. In: Reynolds, ed. Agriculture in development theory. New Haven: Yale University Press. 1975.

MONTEIRO, C. A. A dimensão da pobreza, da fome e da desnutrição no Brasil. Estudos avançados, v.9, n.24, p.195-207, Mai/ago. 1995.

RELATÓRIO SOBRE O DESENVOLVIMENTO HUMANO NO BRASIL. Rio de Janeiro: IPEA; Brasília, DF:PNUD, 1996.

RELATÓRIO SOBRE O DESENVOLVIMENTO MUNDIAL. Washington, Banco Mundial, 1992/93.

RELATÓRIO SOBRE O DESENVOLVIMENTO MUNDIAL. Washington, Banco Mundial, 1989/90.

RICE, D., HODGSON, T.A; KOPSTEIN, A.N. The economic costs of illness: a replication and update. Health Care Financing Review. v.6, n.1, p.61-80, 1985.

ROMER, P.M. Endogeneus technological change. Journal of Political Economic. XCVIII. p.71-102, 1990. 
SEROA DA MOTA, R.; MENDES, A. P. Estimativas de custos de saúde associados à poluição hídrica no Brasil. In: Seroa da Mota, R., ed. Contabilidade ambiental: teoria, metodologia e estudos de casos no Brasil. Rio de Janeiro: IPEA, 1995. cap.8, p.81-92.

SPANIER, J. A orientação americana da política externa. In: La politica exterior norteamericana a partir de la segunda guerra mundial. Buenos Aires: Grupo Editor Latinoamericano,1991. p.18-26.

STERN, N. Growth theories, old and new, and the role of agriculture in economic development. London: Toyota International Centre Economics, 1994.149p.

STIGLITZ, J. The efficiency wage hypothesis, surplus labor and the distribution of income in LDCs. Oxford Economic Papers. v.28, p.185-207, 1978.

SCHULTZ, T. W. Investiment in Human Capital. American Economic Review. LI mar, 1961.

THOMAS, D.; STRAUSS, J.; Henriques, M. H. Child survival, height for age and household characteristics in Brazil. Journal of Development Economics, v.33, p.197-234,1990.

WOLFE, B \& BERHRMAN, R. Women's schooling and children,s health. Journal of Health Economics. v.6, p.239-254. 1987. 
ANEXO 


\section{ANEXO}

Página

Tabela A1 - Resultados da estimação das equações de participação para as mulheres saudáveis e doentes da região Centro-Oeste, 1989.

Tabela A2 - Resultados da estimação das equações de rendimentos para as mulheres saudáveis e doentes da região Centro-Oeste, 1989.

Tabela A3 - Resultados da estimação das equações de participação para mulheres saudáveis e doentes da região Sudeste, 1989.

Tabela A.4 - Resultados da estimação das equações de rendimentos para mulheres saudáveis e doentes da região Sudeste, 1989.

Tabela A.5 - Resultados da estimação das equações de participação para mulheres saudáveis e doentes da região Sul, 1989.

Tabela A.6 - Resultados da estimação das equações de rendimentos para mulheres saudáveis e doentes da região Sul, 1989.

Tabela A.7 - Resultados da estimação das equações de participação para mulheres saudáveis e doentes da região Nordeste, 1989.

Tabela A.8 - Resultados da estimação das equações de rendimentos para mulheres saudáveis e doentes da região Nordeste, 1989.

Tabela A.9 - Resultados da estimação das equações de participação para mulheres saudáveis e doentes da região Norte, 1989.

Tabela A.10 - Resultados da estimação das equações de rendimentos para mulheres saudáveis e doentes da região Norte, 1989.

Tabela A.11- Resultados da estimação das equações de participação para mulheres saudáveis e doentes do setor Urbano, 1989. 
Tabela A.12 - Resultados da estimação das equações de rendimentos para mulheres saudáveis e doentes do setor Urbano, 1989.

Tabela A.13 - Resultados da estimação das equações de participação para mulheres saudáveis e doentes do setor Rural, 1989.

Tabela A.14 - Resultados da estimação das equações de rendimentos para mulheres saudáveis e doentes do setor Rural, 1989.

Tabela A.15 - Resultados da estimação das médias de rendimentos para homens saudáveis e doentes por região e setor, 1989.

Tabela A.16 - Resultados da estimação das médias de rendimentos para mulheres saudáveis e doentes por região e setor, 1989. 
Tabela A1 - Resultados da estimação das equações de participação para as mulheres saudáveis e doentes da região Centro-Oeste, 1989.

\begin{tabular}{|c|c|c|}
\hline \multirow[t]{2}{*}{ Variável } & \multicolumn{2}{|c|}{ Eauação de Participação } \\
\hline & Saudável & Doentes \\
\hline \multirow[t]{2}{*}{ Constante } & $-2,692$ & $-1,731$ \\
\hline & $(-6,95) *$ & $(-2,19)^{* *}$ \\
\hline \multirow[t]{2}{*}{ Idade } & 0,138 & 0,0802 \\
\hline & $(7,50)^{*}$ & $(1,91)^{* * *}$ \\
\hline \multirow{2}{*}{ Idade2 } & $-0,00175$ & $-0,00120$ \\
\hline & $(-7,74)^{*}$ & $(-2,21)^{* *}$ \\
\hline \multirow[t]{2}{*}{ Educação } & 0,0901 & 0,0936 \\
\hline & $(8,10) *$ & $(4,76) *$ \\
\hline \multirow[t]{2}{*}{ Idade $\mathrm{x}$ educação } & $-0,00119$ & 0,00171 \\
\hline & $(-2,14)^{* *}$ & $(1,29)$ \\
\hline \multirow[t]{2}{*}{ Rendanãosalarial } & $-0,00145$ & $-0,00352$ \\
\hline & $(-3,81)^{*}$ & $(-1,52)$ \\
\hline \multirow[t]{2}{*}{ Filho2 } & $-0,188$ & $-0,238$ \\
\hline & $(-2,97)^{*}$ & $(-1,68)^{* *}$ \\
\hline \multirow[t]{2}{*}{ Filho3-5 } & $-0,0524$ & 0,0319 \\
\hline & $(-0,93)$ & $(0,25)$ \\
\hline \multirow{2}{*}{ Filho6-12 } & 0,00203 & 0,0878 \\
\hline & $(0,06)$ & $(1,26)$ \\
\hline \multirow{2}{*}{ Filho13 } & $-0,0963$ & 0,0476 \\
\hline & $(-2,32)^{* *}$ & $(0,48)$ \\
\hline \multirow[t]{2}{*}{ Filha13 } & 0,0974 & 0,129 \\
\hline & $(2,24)^{* *}$ & $(1,08)$ \\
\hline \multirow[t]{2}{*}{ Urbano } & 0,391 & 0,241 \\
\hline & $(5,36) *$ & $(1,57)$ \\
\hline \multirow[t]{2}{*}{ Pardo } & $-0,332$ & $-0,458$ \\
\hline & $(-2,04)^{* *}$ & $(-1,51)$ \\
\hline \multirow[t]{2}{*}{ Bramarel } & $-0,372$ & $-0,460$ \\
\hline & $(-2,26)$ & $(-1,51)$ \\
\hline \multirow[t]{2}{*}{ Chefe } & 0,566 & 0,240 \\
\hline & $(3,56)^{* *}$ & $(0,89)$ \\
\hline \multirow[t]{2}{*}{ Conjuge } & $-0,464$ & $-0,546$ \\
\hline & $(-3,10)^{*}$ & $(-2,14) * *$ \\
\hline \multirow[t]{2}{*}{ Filho } & 0,0930 & 0,172 \\
\hline & $(0,58)$ & $(0,76)$ \\
\hline \multirow[t]{2}{*}{ Outros } & 1,048 & 1,038 \\
\hline & $(4,37)^{*}$ & $(2,42) * *$ \\
\hline Qui-quadrado & $486,62 *$ & $145,48^{*}$ \\
\hline Observações & 2587 & 647 \\
\hline
\end{tabular}

Obs.: Os testes t estão entre parênteses abaixo dos coeficientes.

* Indica significativo a $1 \%$.

** Indica significativo a $5 \%$.

$* * *$ Indica significativo a $10 \%$. 
Tabela A2 - Resultados da estimação das equações de rendimentos para as mulheres saudáveis e doentes da região Centro-Oeste, 1989.

\begin{tabular}{lcc}
\hline \multirow{2}{*}{ Variável } & \multicolumn{2}{c}{ Equação de Rendimento } \\
\cline { 2 - 3 } & Saudável & Doentes \\
\hline Constante & $-4,252$ & $-5,425$ \\
Idade & $(-11,83)^{*}$ & $(-5,33)^{*}$ \\
& 0,111 & 0,106 \\
Idade2 & $(7,01)^{*}$ & $(2,08)^{* *}$ \\
& $-0,00120$ & $-0,00133$ \\
Educação & $(-6,12)^{*}$ & $(-1,96)^{* *}$ \\
& 0,140 & 0,215 \\
Idade x educação & $(13,75)^{*}$ & $(7,75)^{*}$ \\
& $-0,000195$ & 0,00131 \\
Urbano & $(-0,37)$ & $(0,77)$ \\
& 0,215 & 0,256 \\
Pardo & $(2,42)^{* *}$ & $(1,13)$ \\
& 0,245 & 0,00509 \\
Bramarel & $(1,81)^{* * *}$ & $(0,01)$ \\
& 0,308 & 0,210 \\
Lâmbda & $(2,23)^{* *}$ & $(0,57)$ \\
& 0,204 & 1,229 \\
Teste F & $(2,31)^{* *}$ & $(4,43)^{*}$ \\
\hline Observações & $78,16^{*}$ & $20,84^{*}$ \\
\hline
\end{tabular}

Obs.: Os testes t estão entre parênteses abaixo dos coeficientes.

* Indica significativo a $1 \%$.

** Indica significativo a $5 \%$.

$* * *$ Indica significativo a $10 \%$. 
Tabela A3 - Resultados da estimação das equações de participação para mulheres saudáveis e doentes da região Sudeste, 1989.

\begin{tabular}{|c|c|c|}
\hline \multirow[t]{2}{*}{ Variável } & \multicolumn{2}{|c|}{ Equação de Participação } \\
\hline & Saudável & Doentes \\
\hline Constante & $\begin{array}{c}-3,069 \\
(-8,98)^{*}\end{array}$ & $\begin{array}{c}-1,403 \\
(-1,98)^{* *}\end{array}$ \\
\hline Idade & $\begin{array}{c}0,166 \\
(10,61)^{*}\end{array}$ & $\begin{array}{c}0,0675 \\
(1,79)^{* * *}\end{array}$ \\
\hline Idade2 & $\begin{array}{l}-0,00212 \\
(-11,34)^{*}\end{array}$ & $\begin{array}{l}-0,000879 \\
(-1,85) * * *\end{array}$ \\
\hline Educação & $\begin{array}{l}0,0868 \\
(8,56)^{*}\end{array}$ & $\begin{array}{l}0,0610 \\
(3,19)^{*}\end{array}$ \\
\hline Idade $\mathrm{x}$ educação & $\begin{array}{l}-0,00251 \\
(-5,51)^{*}\end{array}$ & $\begin{array}{c}-0,000886 \\
(-0,76)\end{array}$ \\
\hline Rendanãosalarial & $\begin{array}{c}-0,000461 \\
(-1,31)\end{array}$ & $\begin{array}{l}-0,0102 \\
(-2,86)^{*}\end{array}$ \\
\hline Filho2 & $\begin{array}{c}-0,543 \\
(-8,51)^{*}\end{array}$ & $\begin{array}{c}-0,428 \\
(-2,87)^{*}\end{array}$ \\
\hline Filho3-5 & $\begin{array}{c}-0,00913 \\
(-0,16)\end{array}$ & $\begin{array}{l}-0,174 \\
(-1,09)\end{array}$ \\
\hline Filho6-12 & $\begin{array}{c}-0,125 \\
(-3,97)^{*}\end{array}$ & $\begin{array}{c}0,176 \\
(2,01)^{* *}\end{array}$ \\
\hline Filho13 & $\begin{array}{c}-0,0624 \\
(-1,89)^{* * *}\end{array}$ & $\begin{array}{c}-0,275 \\
(-2,45)^{* *}\end{array}$ \\
\hline Filha13 & $\begin{array}{l}0,0223 \\
(0,55)\end{array}$ & $\begin{array}{c}0,242 \\
(1,79)^{* * *}\end{array}$ \\
\hline Urbano & $\begin{array}{c}0,374 \\
(4,65)^{*}\end{array}$ & $\begin{array}{c}0,584 \\
(3,21)^{*}\end{array}$ \\
\hline Pardo & $\begin{array}{c}-0,193 \\
(-1,96)^{* *}\end{array}$ & $\begin{array}{c}0,0378 \\
(0,16)\end{array}$ \\
\hline Bramarel & $\begin{array}{c}-0,362 \\
(-3,96)^{*}\end{array}$ & $\begin{array}{c}0,0437 \\
(0,20)\end{array}$ \\
\hline Chefe & $\begin{array}{c}0,475 \\
(2,90)^{*}\end{array}$ & $\begin{array}{l}0,189 \\
(0,72)\end{array}$ \\
\hline Conjuge & $\begin{array}{c}-0,163 \\
(-1,035)\end{array}$ & $\begin{array}{c}-0,883 \\
(-3,80)^{*}\end{array}$ \\
\hline Filho & $\begin{array}{l}0,0811 \\
(0,48)\end{array}$ & $\begin{array}{l}-0,110 \\
(-0,51)\end{array}$ \\
\hline Outros & $\begin{array}{c}1,040 \\
(3,74)^{*}\end{array}$ & \\
\hline Qui-quadrado & $431,87 *$ & $145,57 *$ \\
\hline Observações & 3098 & 603 \\
\hline
\end{tabular}

Obs.: Os testes $t$ estão entre parênteses abaixo dos coeficientes.

* Indica significativo a $1 \%$.

** Indica significativo a 5\%.

*** Indica significativo a $10 \%$. 
Tabela A.4 - Resultados da estimação das equações de rendimentos para mulheres saudáveis e doentes da região Sudeste, 1989.

\begin{tabular}{lcc}
\hline Variável & \multicolumn{2}{c}{ Eauação de Rendimento } \\
\cline { 2 - 3 } Constante & Saudável & Doentes \\
\hline \multirow{2}{*}{ Idade } & $-4,030$ & $-3,519^{*}$ \\
& $(-11,62)^{*}$ & $(-5,58)$ \\
Idade2 & 0,104 & 0,0750 \\
& $(7,04)^{*}$ & $(2,45)^{* *}$ \\
Educação & $-0,00119$ & $-0,000821$ \\
& $(-6,58)^{*}$ & $(-2,12)^{* *}$ \\
Idade x educação & 0,134 & 0,135 \\
& $(14,51)^{*}$ & $(9,05)$ \\
Urbano & 0,000390 & $-0,000148$ \\
& $(0,93)$ & $(-0,14)$ \\
Pardo & 0,250 & 0,431 \\
& $(2,69)^{*}$ & $(2,10)^{* *}$ \\
Bramarel & 0,0618 & 0,113 \\
& $(0,74)$ & $(0,56)$ \\
Lâmbda & 0,385 & 0,185 \\
& $(4,79)^{*}$ & $(0,98)$ \\
Teste F & 0,193 & 0,136 \\
Observações & $(2,03)^{* *}$ & $(0,79)$ \\
\hline Obs.: Os tes & $137,42^{*}$ & $23,87^{*}$ \\
\hline
\end{tabular}

Obs.: Os testes t estão entre parênteses abaixo dos coeficientes.

* Indica significativo a $1 \%$.

** Indica significativo a $5 \%$. 
Tabela A.5 - Resultados da estimação das equações de participação para mulheres saudáveis e doentes da região Sul, 1989.

\begin{tabular}{|c|c|c|}
\hline \multirow[t]{2}{*}{ Variável } & \multicolumn{2}{|c|}{ Equação de Particinação } \\
\hline & Saudável & Doentes \\
\hline Constante & $\begin{array}{c}-1,989 \\
(-5,67)^{*}\end{array}$ & $\begin{array}{l}0,379 \\
(0,39)\end{array}$ \\
\hline Idade & $\begin{array}{c}0,110 \\
(7,00)^{*}\end{array}$ & $\begin{array}{c}0,0405 \\
(0,93)\end{array}$ \\
\hline Idade2 & $\begin{array}{c}-0,00150 \\
(-7,98)^{*}\end{array}$ & $\begin{array}{c}-0,000759 \\
(-1,44)\end{array}$ \\
\hline Educação & $\begin{array}{l}0,0773 \\
(7,37)^{*}\end{array}$ & $\begin{array}{c}0,0444 \\
(2,11)^{* *}\end{array}$ \\
\hline Idade $x$ educação & $\begin{array}{c}-0,000567 \\
(-1,11)\end{array}$ & $\begin{array}{c}0,000982 \\
(0,70)\end{array}$ \\
\hline Rendanãosalarial & $\begin{array}{c}-0,00159 * \\
(-3,62)\end{array}$ & $\begin{array}{c}-0,00404 \\
(-1,47)\end{array}$ \\
\hline Filho2 & $\begin{array}{c}-0,491 * \\
(-7,53)\end{array}$ & $\begin{array}{c}-0,470 \\
(-2,60)^{*}\end{array}$ \\
\hline Filho3-5 & $\begin{array}{c}-0,190^{*} \\
(-3,28)\end{array}$ & $\begin{array}{c}-0,369 \\
(-2,08)^{* *}\end{array}$ \\
\hline Filho6-12 & $\begin{array}{l}0,0196 \\
(0,59)\end{array}$ & $\begin{array}{c}0,000608 \\
(0,007)\end{array}$ \\
\hline Filho13 & $\begin{array}{c}-0,106 \\
(-2,74)^{*}\end{array}$ & $\begin{array}{c}0,0861 \\
(0,81)\end{array}$ \\
\hline Filha13 & $\begin{array}{c}-0,0525 \\
(-1,24)\end{array}$ & $\begin{array}{c}-0,277 \\
(-1,80)^{* * *}\end{array}$ \\
\hline Urbano & $\begin{array}{c}0,408 \\
(7,04)^{*}\end{array}$ & $\begin{array}{c}0,580 \\
(3,76)^{*}\end{array}$ \\
\hline Pardo & $\begin{array}{c}-0,395 \\
(2,47)^{* *}\end{array}$ & $\begin{array}{c}-1,208 \\
(-2,24)^{* *}\end{array}$ \\
\hline Bramarel & $\begin{array}{c}-0,359 \\
(-2,49)^{* *}\end{array}$ & $\begin{array}{c}-1,318 \\
(-2,57)^{*}\end{array}$ \\
\hline Chefe & $\begin{array}{c}0,609 \\
(3,83)^{*}\end{array}$ & $\begin{array}{l}0,178 \\
(0,56)\end{array}$ \\
\hline Conjuge & $\begin{array}{l}-0,239 \\
(-1,59)\end{array}$ & $\begin{array}{l}-0,362 \\
(-1,21)\end{array}$ \\
\hline Filho & $\begin{array}{c}0,0366 \\
(0,23)\end{array}$ & $\begin{array}{l}-0,273 \\
(-0,91)\end{array}$ \\
\hline Outros & $\begin{array}{c}1,303 \\
(3,90)^{*}\end{array}$ & \\
\hline Qui-quadrado & $590,77^{*}$ & $89,18^{*}$ \\
\hline Observações & 3188 & 468 \\
\hline
\end{tabular}

Obs.: Os testes t estão entre parênteses abaixo dos coeficientes.

* Indica significativo a $1 \%$.

** Indica significativo a 5\%.

$* * *$ Indica significativo a $10 \%$. 
Tabela A.6 - Resultados da estimação das equações de rendimentos para mulheres saudáveis e doentes da região Sul, 1989.

\begin{tabular}{lcc}
\hline Variável & \multicolumn{2}{c}{ Eauação de Rendimento } \\
\cline { 2 - 3 } Constante & Saudável & Doentes \\
& $-3,960$ & $-4,292$ \\
Idade & $(-13,55)^{*}$ & $(-6,47)^{*}$ \\
& 0,111 & 0,0894 \\
Idade2 & $(8,71)^{*}$ & $(2,66)^{*}$ \\
& $-0,00125$ & $-0,000895$ \\
Educação & $(-7,88)^{*}$ & $(-2,08)^{* *}$ \\
& 0,133 & 0,156 \\
Idade x educação & $(15,78)^{*}$ & $(8,90)^{*}$ \\
& $-0,000133$ & $-0,00104$ \\
Urbano & $(-0,31)$ & $(-0,81)$ \\
& 0,276 & 0,365 \\
Pardo & $(4,34)^{*}$ & $(1,99)^{* *}$ \\
& $-0,0246$ & 0,267 \\
Bramarel & $(-0,19)$ & $(0,77)$ \\
& 0,0323 & 0,301 \\
Lâmbda & $(0,29)$ & $(0,99)$ \\
& 0,220 & 0,274 \\
Teste F & $(2,64)^{*}$ & $(1,15)$ \\
Observações & $98,61^{*}$ & $20,77^{*}$ \\
\hline Obs: Os testes & 3188 & 468 \\
\hline
\end{tabular}

Obs.: Os testes t estão entre parênteses abaixo dos coeficientes.

* Indica significativo a $1 \%$.

** Indica significativo a $5 \%$. 
Tabela A.7 - Resultados da estimação das equações de participação para mulheres saudáveis e doentes da região Nordeste, 1989.

\begin{tabular}{|c|c|c|}
\hline \multirow[t]{2}{*}{$\overline{\text { Variável }}$} & \multicolumn{2}{|c|}{ Equação de Participação } \\
\hline & Saudável & Doentes \\
\hline \multirow[t]{2}{*}{ Constante } & $-2,290$ & $-3,724$ \\
\hline & $(-6,97)^{*}$ & $(-6,17)^{*}$ \\
\hline \multirow[t]{2}{*}{ Idade } & 0,0878 & 0,184 \\
\hline & $(5,82) *$ & $(5,87) *$ \\
\hline \multirow[t]{2}{*}{ Idade 2} & $-0,00106$ & $-0,00242$ \\
\hline & $(-5,80) *$ & $(-6,04)^{*}$ \\
\hline \multirow{2}{*}{ Educação } & 0,0861 & 0,0933 \\
\hline & $(7,96) *$ & $(5,07) *$ \\
\hline \multirow[t]{2}{*}{ Idade x educação } & $-0,000373$ & $-0,00229$ \\
\hline & $(-0,75)$ & $(-2,04) * *$ \\
\hline \multirow{2}{*}{ Rendanãosalarial } & $-0,00192$ & $-0,00292$ \\
\hline & $(-3,66)^{*}$ & $(-1,65) * * *$ \\
\hline \multirow[t]{2}{*}{ Filho2 } & $-0,172$ & $-0,0686$ \\
\hline & $(-3,24)^{*}$ & $(-0,69)$ \\
\hline \multirow[t]{2}{*}{ Filho3-5 } & 0,00253 & $-0,158$ \\
\hline & $(0,05)$ & $(-1,64)$ \\
\hline \multirow[t]{2}{*}{ Filho6-12 } & 0,0626 & 0,0416 \\
\hline & $(2,28) * *$ & $(0,77)$ \\
\hline \multirow[t]{2}{*}{ Filho13 } & $-0,0418$ & 0,0692 \\
\hline & $(-1,30)$ & $(0,93)$ \\
\hline \multirow[t]{2}{*}{ Filha13 } & $-0,00588$ & 0,129 \\
\hline & $(-0,16)$ & $(1,49)$ \\
\hline \multirow[t]{2}{*}{ Urbano } & 0,234 & 0,261 \\
\hline & $(4,01)^{*}$ & $(2,37)^{* *}$ \\
\hline \multirow[t]{2}{*}{ Pardo } & $-0,193$ & $-0,112$ \\
\hline & $(-1,59)$ & $(-0,48)$ \\
\hline \multirow[t]{2}{*}{ Bramarel } & $-0,280$ & $-0,138$ \\
\hline & $(-2,12) * *$ & $(-0,56)$ \\
\hline \multirow[t]{2}{*}{ Chefe } & 0,594 & 0,428 \\
\hline & $(3,87) *$ & $(1,70) * * *$ \\
\hline \multirow[t]{2}{*}{ Conjuge } & $-0,073$ & $-0,237$ \\
\hline & $(-0,49)$ & $(-0,97)$ \\
\hline \multirow[t]{2}{*}{ Filho } & 0,197 & $-0,0952$ \\
\hline & $(1,24)$ & $(-0,42)$ \\
\hline \multirow{2}{*}{ Outros } & 1,434 & 1,013 \\
\hline & $(6,50) *$ & $(2,54)$ \\
\hline Qui-quadrado & $495,24 *$ & $148,88^{*}$ \\
\hline Observações & 2988 & 912 \\
\hline
\end{tabular}

Obs.: Os testes t estão entre parênteses abaixo dos coeficientes.

* Indica significativo a $1 \%$.

** Indica significativo a $5 \%$.

$* * *$ Indica significativo a $10 \%$. 
Tabela A.8 - Resultados da estimação das equações de rendimentos para mulheres saudáveis e doentes da região Nordeste, 1989.

\begin{tabular}{|c|c|c|}
\hline \multirow[t]{2}{*}{ Variável } & \multicolumn{2}{|c|}{ Equação de Rendimento } \\
\hline & Saudável & Doentes \\
\hline \multirow[t]{2}{*}{ Constante } & $-4,595$ & $-4,464$ \\
\hline & $(-12,56)^{*}$ & $(-4,79) *$ \\
\hline \multirow[t]{2}{*}{ Idade } & 0,0901 & 0,121 \\
\hline & $(5,88) *$ & $(2,94)^{*}$ \\
\hline \multirow[t]{2}{*}{ Idade2 } & $-0,000917$ & $-0,00149$ \\
\hline & $(-4,84)^{*}$ & $(-2,76)^{*}$ \\
\hline \multirow{2}{*}{ Educação } & 0,157 & 0,102 \\
\hline & $(13,70)^{*}$ & $(5,14)^{*}$ \\
\hline \multirow[t]{2}{*}{ Idade $x$ educação } & 0,0000865 & 0,00235 \\
\hline & $(0,16)$ & $(1,96)^{*}$ \\
\hline \multirow[t]{2}{*}{ Urbano } & 0,376 & 0,119 \\
\hline & $(4,89) *$ & $(0,85)$ \\
\hline \multirow[t]{2}{*}{ Pardo } & $-0,0100$ & 0,00997 \\
\hline & $(-0,08)$ & $(0,04)$ \\
\hline \multirow[t]{2}{*}{ Bramarel } & $-0,0435$ & 0,183 \\
\hline & $(-0,30)$ & $(0,75)$ \\
\hline \multirow[t]{2}{*}{ Lâmbda } & 0,518 & 0,209 \\
\hline & $(4,61) *$ & $(0,96)$ \\
\hline Teste F & $93,67 *$ & $19,13^{*}$ \\
\hline Observações & 2988 & 912 \\
\hline
\end{tabular}

Obs.: Os testes t estão entre parênteses abaixo dos coeficientes.

* Indica significativo a $1 \%$. 
Tabela A.9 - Resultados da estimação das equações de participação para mulheres saudáveis e doentes da região Norte, 1989.

\begin{tabular}{|c|c|c|}
\hline \multirow[t]{2}{*}{ Variável } & \multicolumn{2}{|c|}{ Equação de Participação } \\
\hline & Saudável & Doentes \\
\hline \multirow[t]{2}{*}{ Constante } & $-2,641$ & $-3,370$ \\
\hline & $(-5,19) *$ & $(-3,32) *$ \\
\hline \multirow[t]{2}{*}{ Idade } & 0,170 & 0,137 \\
\hline & $(8,05)^{*}$ & $(2,89) *$ \\
\hline \multirow[t]{2}{*}{ Idade2 } & $-0,00206$ & $-0,00183$ \\
\hline & $(-8,13)^{*}$ & $(-3,07) *$ \\
\hline \multirow[t]{2}{*}{ Educação } & 0,0924 & 0,0690 \\
\hline & $(6,66) *$ & $(2,41) * *$ \\
\hline \multirow[t]{2}{*}{ Idade $\mathrm{x}$ educação } & $-0,000754$ & 0,00173 \\
\hline & $(-1,19)$ & $(1,06)$ \\
\hline \multirow[t]{2}{*}{ Rendanãosalarial } & $-0,00116$ & $-0,00164$ \\
\hline & $(-2,34) * *$ & $(-1,05)$ \\
\hline \multirow{2}{*}{ Filho2 } & $-0,133$ & $-0,0505$ \\
\hline & $(-1,88) * * *$ & $(-0,25)$ \\
\hline \multirow[t]{2}{*}{ Filho3-5 } & $-0,145$ & 0,0241 \\
\hline & $(-2,35) * *$ & $(0,15)$ \\
\hline \multirow[t]{2}{*}{ Filho6-12 } & 0,0513 & 0,104 \\
\hline & $(1,41)$ & $(1,06)$ \\
\hline \multirow[t]{2}{*}{ Filho13 } & 0,0235 & $-0,0666$ \\
\hline & $(0,56)$ & $(-0,51)$ \\
\hline \multirow[t]{2}{*}{ Filha13 } & 0,0690 & 0,0971 \\
\hline & $(1,36)$ & $(0,62)$ \\
\hline \multirow[t]{2}{*}{ Pardo } & $-0,629$ & 0,174 \\
\hline & $(-2,09) * *$ & $(0,34)$ \\
\hline \multirow[t]{2}{*}{ Bramarel } & $-0,587$ & 0,351 \\
\hline & $(-1,92) * * *$ & $(0,66)$ \\
\hline \multirow[t]{2}{*}{ Chefe } & 0,106 & 0,322 \\
\hline & $(0,53)$ & $(0,95)$ \\
\hline \multirow[t]{2}{*}{ Conjuge } & $-0,575$ & $-0,277$ \\
\hline & $(-2,97) *$ & $(-0,81)$ \\
\hline \multirow[t]{2}{*}{ Filho } & 0,0349 & 0,416 \\
\hline & $(0,17)$ & $(1,42)$ \\
\hline \multirow[t]{2}{*}{ Outros } & 1,300 & 0,912 \\
\hline & $(4,11)^{*}$ & $(2,02) * *$ \\
\hline Qui-quadrado & $347,81 *$ & $65,68 *$ \\
\hline Observações & 1736 & 351 \\
\hline
\end{tabular}

Obs.: Os testes t estão entre parênteses abaixo dos coeficientes.

* Indica significativo a $1 \%$.

** Indica significativo a 5\%.

$* * *$ Indica significativo a $10 \%$. 
Tabela A.10 - Resultados da estimação das equações de rendimentos para mulheres saudáveis e doentes da região Norte, 1989.

\begin{tabular}{lcc}
\hline Variável & \multicolumn{2}{c}{ Eauação de Rendimento } \\
\cline { 2 - 3 } Constante & Saudável & Doentes \\
\hline \multirow{2}{*}{ Idade } & $-3,735$ & $-4,684$ \\
& $(-8,84)^{*}$ & $(-3,67)^{*}$ \\
Idade2 & 0,111 & 0,113 \\
& $(6,04)^{*}$ & $(2,28)^{* *}$ \\
Educação & $-0,00125$ & $-0,00138$ \\
& $(-5,57)^{*}$ & $(-2,10)^{* *}$ \\
Idade x educação & 0,129 & 0,132 \\
& $(10,38)^{*}$ & $(3,91)^{*}$ \\
Pardo & 0,000256 & 0,00198 \\
& $(0,45)$ & $(1,08)$ \\
Bramarel & $-0,0796$ & 0,331 \\
& $(-0,36)$ & $(0,61)$ \\
Lâmbda & 0,149 & 0,573 \\
& $(0,66)$ & $(1,03)$ \\
Teste F & 0,436 & 0,894 \\
Observações & $(3,93)^{*}$ & $(2,25)^{* *}$ \\
\hline Obs: Os testes testâ & $58,69^{*}$ & $7,25^{*}$ \\
\hline
\end{tabular}

Obs.: Os testes t estão entre parênteses abaixo dos coeficientes.

* Indica significativo a $1 \%$.

** Indica significativo a $5 \%$. 
Tabela A.11- Resultados da estimação das equações de participação para mulheres saudáveis e doentes do setor Urbano, 1989.

\begin{tabular}{|c|c|c|}
\hline \multirow[t]{2}{*}{ Variável } & \multicolumn{2}{|c|}{ Equação de Participação } \\
\hline & Saudável & Doentes \\
\hline \multirow[t]{2}{*}{ Constante } & $-2,503$ & $-2,632$ \\
\hline & $(-12,42)^{*}$ & $(-6,08) *$ \\
\hline \multirow[t]{2}{*}{ Idade } & 0,147 & 0,143 \\
\hline & $(15,73)^{*}$ & $(6,32)^{*}$ \\
\hline \multirow{2}{*}{ Idade2 } & $-0,00188$ & $-0,00192$ \\
\hline & $(-16,85) *$ & $(-6,70)^{*}$ \\
\hline \multirow{2}{*}{ Educação } & 0,0837 & 0,0615 \\
\hline & $(14,03)^{*}$ & $(5,50)^{*}$ \\
\hline \multirow[t]{2}{*}{ Idade $x$ educação } & $-0,00166$ & $-0,00103$ \\
\hline & $(-6,06)^{*}$ & $(-1,49)$ \\
\hline \multirow[t]{2}{*}{ Rendanãosalarial } & $-0,000927$ & $-0,00384$ \\
\hline & $(-4,44)^{*}$ & $(-3,15)^{*}$ \\
\hline \multirow[t]{2}{*}{ Filho2 } & $-0,414$ & $-0,265$ \\
\hline & $(-11,23)^{*}$ & $(-3,14)^{*}$ \\
\hline \multirow[t]{2}{*}{ Filho3-5 } & $-0,0353$ & $-0,197$ \\
\hline & $(-1,09)$ & $(-2,26) * *$ \\
\hline \multirow[t]{2}{*}{ Filho6-12 } & $-0,0412$ & 0,0981 \\
\hline & $(-2,21)^{* *}$ & $(2,10) * *$ \\
\hline \multirow[t]{2}{*}{ Filho13 } & $-0,0469$ & $-0,0970$ \\
\hline & $(-2,30)^{* *}$ & $(-1,49)$ \\
\hline \multirow[t]{2}{*}{ Filha13 } & 0,00412 & 0,0897 \\
\hline & $(0,17)$ & $(1,17)$ \\
\hline \multirow[t]{2}{*}{ Centro } & 0,062 & 0,565 \\
\hline & $(0,96)$ & $(0,43)$ \\
\hline \multirow[t]{2}{*}{ Sudeste } & 0,098 & 0,337 \\
\hline & $(2,36)^{* *}$ & $(3,87)^{*}$ \\
\hline \multirow[t]{2}{*}{ Sul } & 0,180 & 0,201 \\
\hline & $(3,34)^{*}$ & $(1,57)$ \\
\hline \multirow[t]{2}{*}{ Norte } & 0,119 & 0,019 \\
\hline & $(1,47)$ & $(0,11)$ \\
\hline \multirow[t]{2}{*}{ Pardo } & $-0,300$ & $-0,121$ \\
\hline & $(-4,47)$ & $(-0,76)$ \\
\hline \multirow[t]{2}{*}{ Bramarel } & $-0,408$ & $-0,0475$ \\
\hline & $(-6,32) *$ & $(-0,31)$ \\
\hline \multirow[t]{2}{*}{ Chefe } & 0,492 & 0,420 \\
\hline & $(5,43)$ & $(2,62)^{*}$ \\
\hline
\end{tabular}


Tabela A.11- Resultados da estimação das equações de participação para mulheres saudáveis e doentes do setor Urbano, 1989.

\begin{tabular}{lcc}
\hline Conjuge & $-0,189$ & $-0,419$ \\
& $(-2,16)^{* *}$ & $(-2,76)^{*}$ \\
Filho & 0,0903 & 0,172 \\
& $(0,97)$ & $(1,25)$ \\
Outros & 1,160 & 1,455 \\
& $(8,09)^{*}$ & $(5,30)^{*}$ \\
Qui-quadrado & $1374,06^{*}$ & $348,38^{*}$ \\
\hline Observações & 8410 & 1672 \\
\hline
\end{tabular}

Obs.: Os testes t estão entre parênteses abaixo dos coeficientes.

* Indica significativo a $1 \%$.

** Indica significativo a 5\%. 
Tabela A.12 - Resultados da estimação das equações de rendimentos para mulheres saudáveis e doentes do setor Urbano, 1989.

\begin{tabular}{lcc}
\hline \multirow{2}{*}{ Variável } & \multicolumn{2}{c}{ Eauação de Rendimento } \\
\cline { 2 - 3 } & Saudável & Doentes \\
\hline Constante & $-4,583$ & $-4,461$ \\
& $(-25,40)^{*}$ & $(-11,56)^{*}$ \\
Idade & 0,120 & 0,101 \\
& $(14,88)^{*}$ & $(5,35)^{*}$ \\
Idade2 & $-0,00136$ & $-0,00115$ \\
& $(-13,63)^{*}$ & $(-4,69)^{*}$ \\
Educação & 0,144 & 0,139 \\
& $(28,33)^{*}$ & $(15,31)^{*}$ \\
Idade x educação & 0,0000066 & 0,000171 \\
& $(0,03)$ & $(0,28)$ \\
Centro & 0,369 & 0,482 \\
& $(6,66)^{*}$ & $(4,23)^{*}$ \\
Sudeste & 0,399 & 0,633 \\
& $(11,16)^{*}$ & $(8,12)^{*}$ \\
Sul & 0,332 & 0,410 \\
& $(7,20)^{*}$ & $(3,75)^{*}$ \\
Norte & 0,507 & 0,610 \\
& $(7,33)^{*}$ & $(3,90)^{*}$ \\
Pardo & 0,0762 & 0,189 \\
& $(1,40)$ & $(1,47)$ \\
Bramarel & 0,269 & 0,319 \\
& $(5,08)^{*}$ & $(2,60)^{*}$ \\
Lâmbda & 0,333 & 0,361 \\
& $(6,22)^{*}$ & $(3,43)^{*}$ \\
Teste F & $311,27 *$ & $59,92^{*}$ \\
\hline Observações & 8410 & 1672 \\
\hline
\end{tabular}

Obs.: Os testes t estão entre parênteses abaixo dos coeficientes.

* Indica significativo a $1 \%$. 
Tabela A.13 - Resultados da estimação das equações de participação para mulheres saudáveis e doentes do setor Rural, 1989.

\begin{tabular}{|c|c|c|}
\hline \multirow[t]{2}{*}{ Variável } & \multicolumn{2}{|c|}{ Equação de Partici pação } \\
\hline & Saudável & Doentes \\
\hline \multirow[t]{2}{*}{ Constante } & $-2,184$ & $-2,072$ \\
\hline & $(-7,63)^{*}$ & $(-3,80)^{*}$ \\
\hline \multirow{2}{*}{ Idade } & 0,0800 & 0,0612 \\
\hline & $(6,50)^{*}$ & $(2,37) * *$ \\
\hline \multirow[t]{2}{*}{ Idade2 } & $-0,000940$ & $-0,000730$ \\
\hline & $(-6,36)^{*}$ & $(-2,29) * *$ \\
\hline \multirow[t]{2}{*}{ Educação } & 0,0931 & 0,135 \\
\hline & $(7,48) *$ & $(5,63) *$ \\
\hline \multirow[t]{2}{*}{ Idade $x$ educação } & $-0,00105$ & $-0,00380$ \\
\hline & $(-1,86)^{* * *}$ & $(-2,59) *$ \\
\hline \multirow[t]{2}{*}{ Rendanãosalarial } & $-0,000632$ & $-0,0171$ \\
\hline & $(-0,89)$ & $(-2,90)^{*}$ \\
\hline \multirow{2}{*}{ Filho2 } & $-0,208$ & $-0,124$ \\
\hline & $(-4,92)^{*}$ & $(-1,50)$ \\
\hline \multirow[t]{2}{*}{ Filho3-5 } & 0,00301 & $-0,0276$ \\
\hline & $(0,08)$ & $(-0,34)$ \\
\hline \multirow{2}{*}{ Filho6-12 } & 0,0398 & 0,110 \\
\hline & $(1,88)^{* * *}$ & $(2,42)^{* *}$ \\
\hline \multirow[t]{2}{*}{ Filho13 } & $-0,0729$ & $-0,0154$ \\
\hline & $(-2,86)^{*}$ & $(-0,29)$ \\
\hline \multirow[t]{2}{*}{ Filha13 } & 0,0504 & 0,183 \\
\hline & $(1,70) * * *$ & $(2,81) *$ \\
\hline \multirow[t]{2}{*}{ Centro } & $-0,113$ & $-0,184$ \\
\hline & $(-1,32)$ & $(-1,02)$ \\
\hline \multirow[t]{2}{*}{ Sudeste } & 0,034 & 0,081 \\
\hline & $(0,64)$ & $(0,73)$ \\
\hline \multirow[t]{2}{*}{ Sul } & $-0,249$ & $-0,919$ \\
\hline & $(-0,40)$ & $(-0,67)$ \\
\hline \multirow[t]{2}{*}{ Pardo } & 0,0436 & 0,0221 \\
\hline & $(0,48)$ & $(0,12)$ \\
\hline \multirow[t]{2}{*}{ Bramarel } & $-0,0172$ & $-0,0988$ \\
\hline & $(-0,19)$ & $(-0,53)$ \\
\hline
\end{tabular}


Tabela A.13 - Resultados da estimação das equações de participação para mulheres saudáveis e doentes do setor Rural, 1989.

\begin{tabular}{lcc}
\hline Chefe & 0,461 & 0,670 \\
& $(2,90)$ & $(2,45)^{* *}$ \\
Conjuge & $-0,315$ & $-0,173$ \\
& $(-2,07)^{* *}$ & $(-0,67)$ \\
Filho & 0,145 & 0,113 \\
& $(0,91)^{*}$ & $(0,43)$ \\
Outros & 1,278 & 0,113 \\
& $(4,00)^{*}$ & $(0,43)$ \\
Qui-quadrado & $389,05^{*}$ & $93,20^{*}$ \\
\hline Observações & 5187 & 1309 \\
\hline
\end{tabular}

Obs.: Os testes t estão entre parênteses abaixo dos coeficientes.

* Indica significativo a $1 \%$.

** Indica significativo a $5 \%$.

*** Indica significativo a $10 \%$. 
Tabela A.14 - Resultados da estimação das equações de rendimentos para mulheres saudáveis e doentes do setor Rural, 1989.

\begin{tabular}{lcc}
\hline Variável & \multicolumn{2}{c}{ Eauação de Rendimento } \\
\cline { 2 - 3 } & Saudável & Doentes \\
\hline Constante & $-2,817$ & $-2,964$ \\
& $(-9,77)^{*}$ & $(-4,24)^{*}$ \\
Idade & 0,0293 & 0,0684 \\
& $(2,45)^{* *}$ & $(2,39)^{* *}$ \\
Idade2 & $-0,000225$ & $-0,000858$ \\
& $(-1,54)$ & $(-2,37)^{* *}$ \\
Educação & 0,114 & 0,0899 \\
& $(8,75)^{*}$ & $(3,01)^{* *}$ \\
Idade x educação & $-0,000197$ & $-0,000930$ \\
& $(-0,33)$ & $(-0,52)$ \\
Centro & 0,553 & 0,568 \\
& $(5,30)^{*}$ & $(2,78)^{*}$ \\
Sudeste & 0,441 & 0,283 \\
& $(7,12)^{*}$ & $(2,30)^{* *}$ \\
Sul & 0,430 & 0,321 \\
& $(5,94)^{*}$ & $(2,02)^{* *}$ \\
Pardo & 0,0403 & $-0,213$ \\
& $(0,40)$ & $(-1,10)$ \\
Bramarel & 0,206 & $-0,139$ \\
& $(2,00)^{* *}$ & $(-0,69)$ \\
Lâmbda & 0,0615 & 0,0582 \\
Teste F & $(0,70)$ & $(0,30)$ \\
Observações & $48,56^{*}$ & $5,90^{*}$ \\
\hline
\end{tabular}

Obs.: Os testes t estão entre parênteses abaixo dos coeficientes.

* Indica significativo a $1 \%$.

** Indica significativo a $5 \%$. 


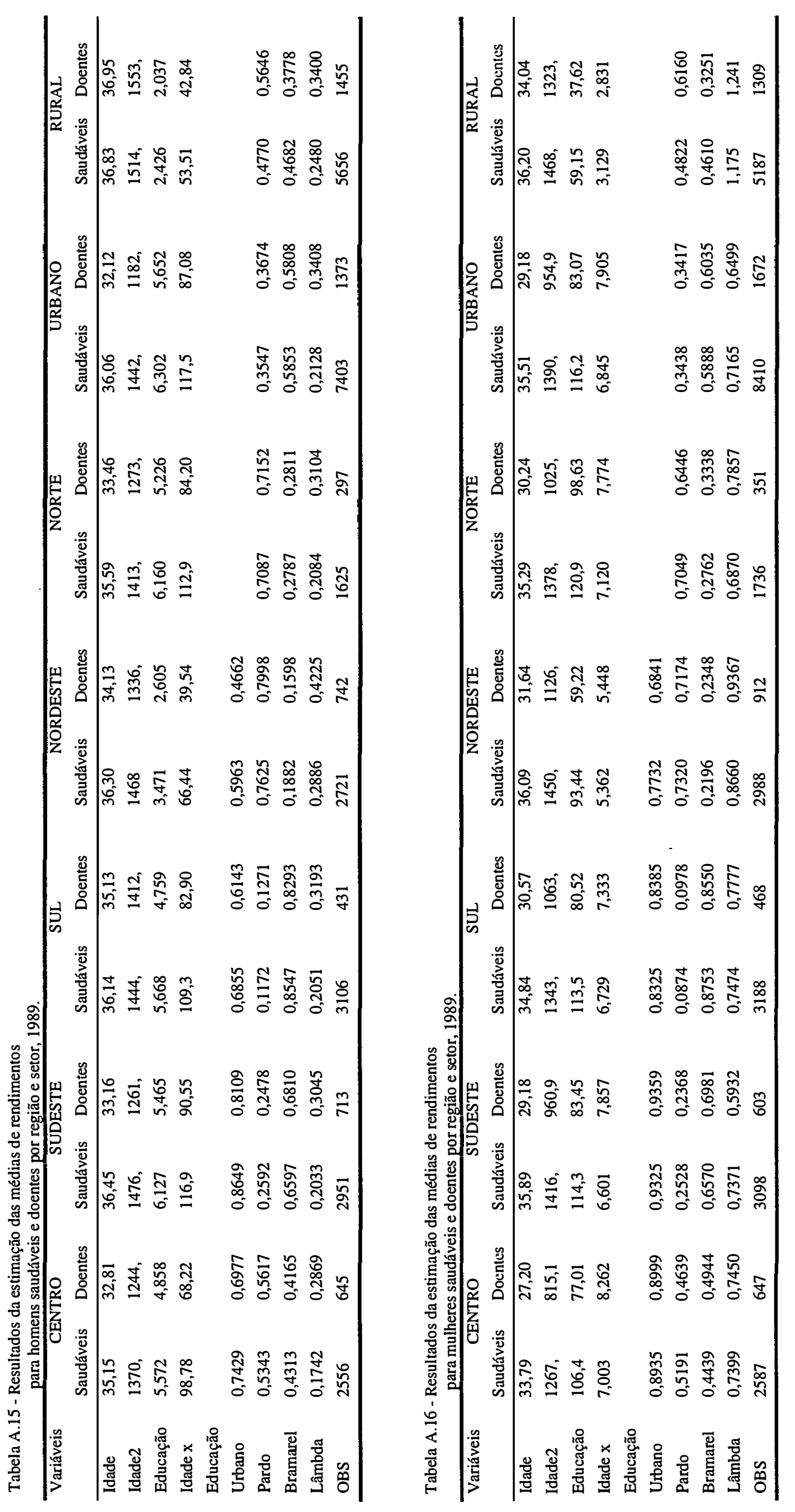

